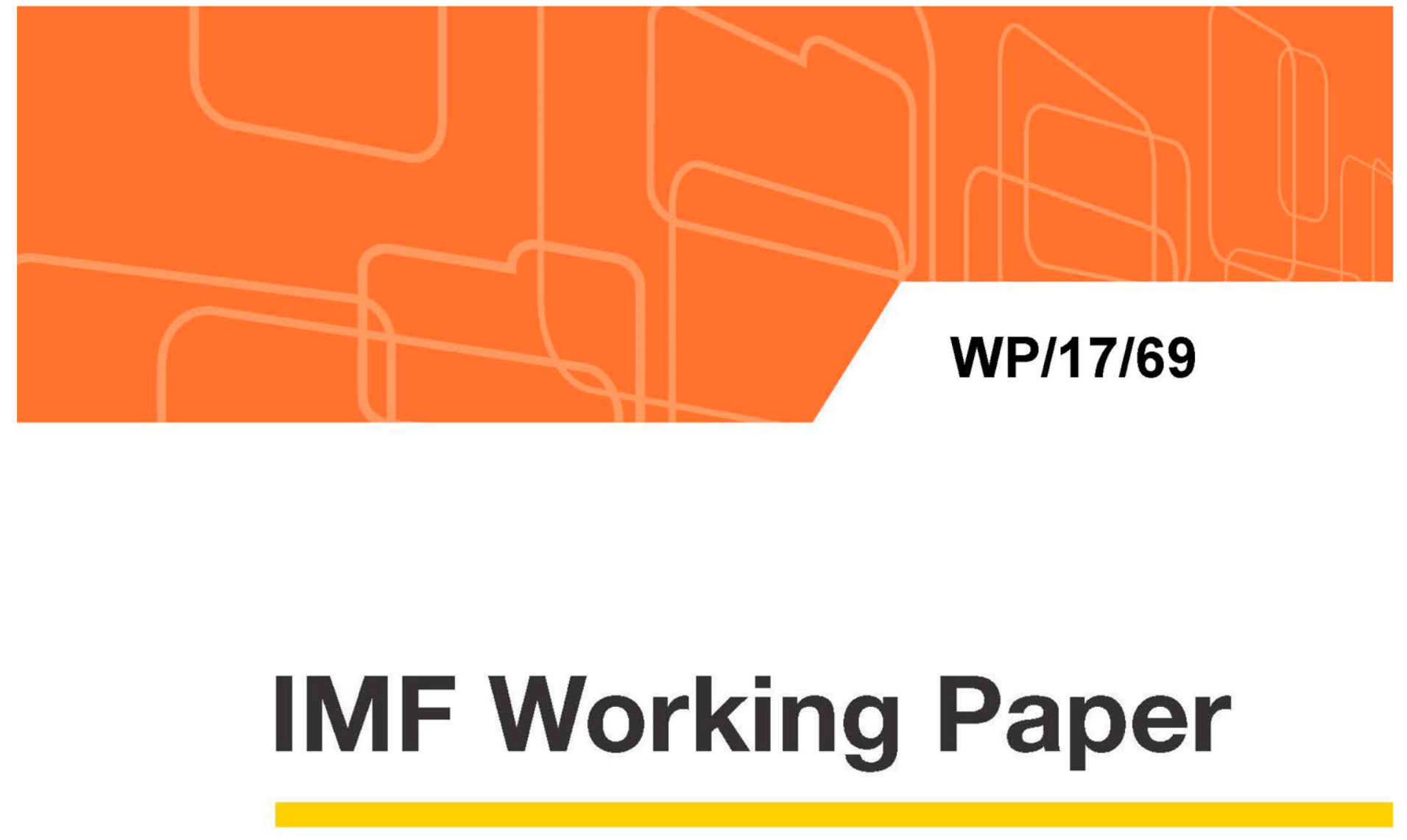

\title{
Managing the Tide: How Do Emerging Markets Respond to Capital Flows?
}

by Atish R. Ghosh, Jonathan D. Ostry, and Mahvash S. Qureshi

IMF Working Papers describe research in progress by the author(s) and are published to elicit comments and to encourage debate. The views expressed in IMF Working Papers are those of the author(s) and do not necessarily represent the views of the IMF, its Executive Board, or IMF management.

$\begin{array}{lllllllllllllllllllllllll}\text { I } & N & T & E & R & N & A & T & \text { I } & \text { O } & \text { N } & \text { A } & L & M & O & N & E & T & A & R & Y & F & \text { U } & N & D\end{array}$ 


\section{WP/17/69}

\section{IMF Working Paper}

\section{Managing the Tide: How Do Emerging Markets Respond to Capital Flows?}

by Atish R. Ghosh, Jonathan D. Ostry, and Mahvash S. Qureshi

IMF Working Papers describe research in progress by the author(s) and are published to elicit comments and to encourage debate. The views expressed in IMF Working Papers are those of the author(s) and do not necessarily represent the views of the IMF, its Executive Board, or IMF management.

I N T E R N A T I O N A L M O N E T A R Y F U N D 


\title{
IMF Working Paper
}

Research Department

\section{Managing the Tide: How Do Emerging Markets Respond to Capital Flows? ${ }^{\dagger}$ \\ Prepared by Atish R. Ghosh, Jonathan D. Ostry, and Mahvash S. Qureshi}

March 2017

\begin{abstract}
IMF Working Papers describe research in progress by the author(s) and are published to elicit comments and to encourage debate. The views expressed in IMF Working Papers are those of the author(s) and do not necessarily represent the views of the IMF, its Executive Board, or IMF management.
\end{abstract}

\begin{abstract}
This paper examines whether-and how_-emerging market economies (EMEs) respond to capital flows to mitigate their untoward consequences. Based on a sample of about 50 EMEs over 2005Q1-2013Q4, we find that EME policy makers respond proactively to capital inflows by using a combination of policy tools: central banks raise the policy interest rate to address economic overheating concerns; intervene in the foreign exchange market to resist currency appreciation pressures; tighten macroprudential measures to dampen credit growth; and deploy capital inflow controls in the face of competitiveness and financial-stability concerns. Contrary to conventional policy advice to EMEs, we find no evidence of counter-cyclical fiscal policy in the face of capital inflows. Overall, policies are more likely to respond, and used in combination, during inflow surges than in more normal times.
\end{abstract}

JEL Classification Numbers: E58, F21, F32, G28

Keywords: capital flows; policy toolkit; capital controls; emerging market economies Authors’ E-Mail Addresses: aghosh@imf.org; jostry@imf.org; mqureshi@imf.org

\footnotetext{
$\dagger$ We thank Naotaka Sugawara for help with data programming, and Eun Sun Jang and Manzoor Gill for excellent research assistance at different stages of the project.
} 


\section{Contents}

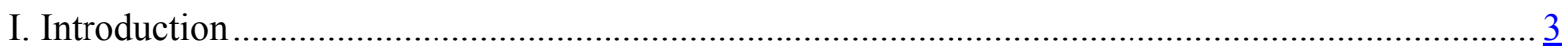

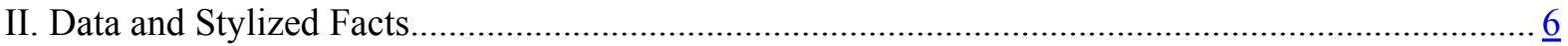

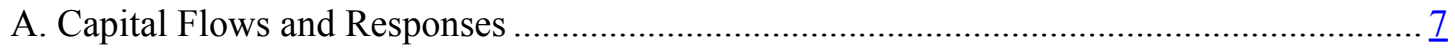

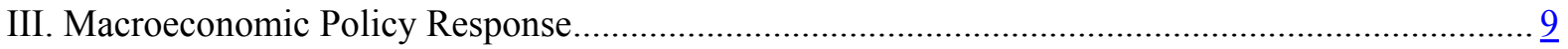

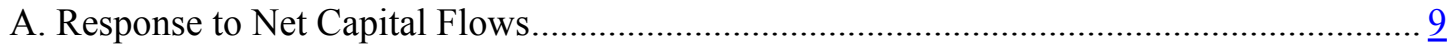

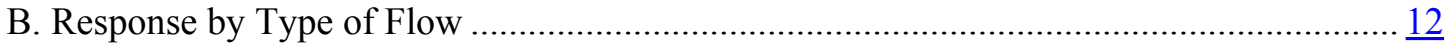

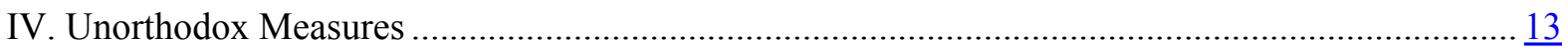

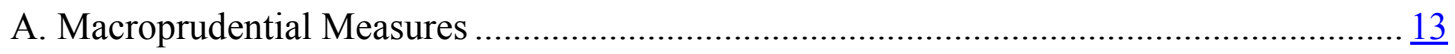

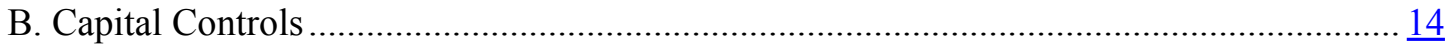

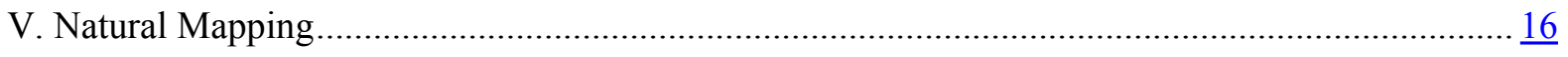

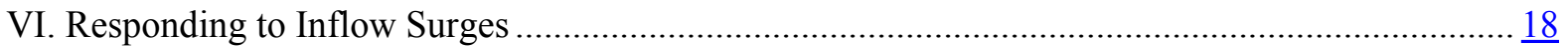

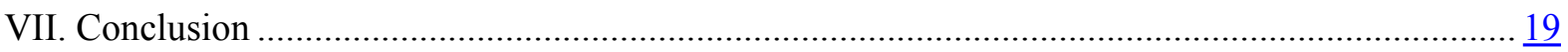

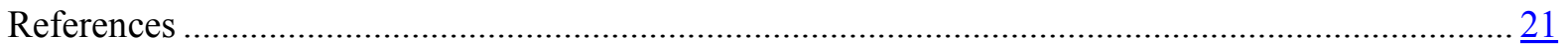

Appendix: Data and Additional Estimation Results ......................................................................... 32

Tables

1. Net Capital Flows and Macroeconomic Policy Response in EMEs, 2005Q1-2013Q4 …............. 27

2. Net Inflows and Outflows and Policy Response in EMEs, 2005Q1-2013Q4 ............................. 27

3. Macroeconomic Policy Response and the Composition of Flows, 2005Q1-2013Q4 …............... 28

4. Net Capital Flows and Macroprudential Policy Response in EMEs, 2005Q1-2013Q4 ................ 29

5. Macroprudential Policies and Composition of Flows, 2005Q1-2013Q4 …................................. $\frac{29}{30}$

6. Net Capital Flows and Capital Controls in EMEs, 2005Q1-2013Q4 .......................................... $\frac{30}{30}$

7. Capital Controls and Composition of Flows, 2005Q1-2013Q4 ............................................... $\frac{30}{31}$

8. Use of Policy Instruments and Risks, 2005Q1-2013Q4 ............................................................. $\frac{31}{32}$

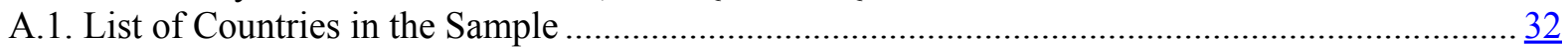

A.2. Variable Description and Data Sources............................................................................. $\frac{33}{34}$

A.3. Tightening of Macroprudential Policies in Selected EMEs, 2005Q1-2013Q4 …...................... $\frac{34}{34}$

A.4. Changes in Capital Controls in EMEs, 2005Q1-2013Q4 .................................................. 34

A.5. Net Capital Flows and FX Intervention in Selected EMEs ................................................. $\frac{35}{36}$

A.6. Net Capital Flows and Policy Rate in Selected EMEs ......................................................... $\frac{36}{36}$

A.7. Net Capital Flows and Policy Rate in Selected EMEs: Additional Covariates ........................... $\frac{37}{38}$

A.8. Net Capital Flows and Fiscal Policy Response in Selected EMEs............................................ $\underline{38}$

A.9. Net Capital Flows and Macroprudential Policy Response in Selected EMEs............................ $\underline{39}$

A.10. Net Capital Flows and Inflow Controls in Selected EMEs …............................................. $\underline{40}$

A.11. Net Capital Flows and Outflow Controls in Selected EMEs................................................... $\underline{40}$

A.12. Macro-Financial Risks in Surges and Normal Flows .......................................................... $\underline{40}$

Figures

1. Capital Flows to EMEs, 2005Q1-2013Q4 ….......................................................................... 23

2. Capital Flows and Macroeconomic Policy Response in EMEs, 2005Q1-2013Q4 ….................... $\underline{23}$

3. Capital Flows and Macroprudential Measures in EMEs, 2005Q1-2013Q4 ….............................24

4. Capital Flows and Inflow Controls in EMEs, 2005Q1-2013Q4 ............................................ 24

5. Policy Instruments and Risks, 2005Q1-2013Q4 …............................................................. 25

6. Policy Responses in Inflow Surges in EMEs ........................................................................ 26

A.1. Policy Responses in Large Outflows in EMEs, 2005Q1-2013Q4 .......................................... $\underline{32}$ 


\section{INTRODUCTION}

The global financial crisis and its aftermath saw boom-bust cycles in cross-border capital flows of unprecedented magnitude, rekindling debates on whether — and how - to deal with these flows. Traditionally, emerging market economies (EMEs) were counseled not to impede capital flows, but to pursue exchange rate flexibility and prudent fiscal policy in the face of large inflows. ${ }^{1}$ In recent years, however, there has been growing recognition that EMEs might usefully take a more proactive stance_-deploying a range of policy tools including prudential measures and capital controls - to better manage capital inflows, on grounds that doing so may leave the economy less susceptible to crisis when the flows eventually recede or reverse (Ostry et al., 2010, 2011; IMF, 2012). But do they do so in practice? That is the question we investigate in this paper.

Policy makers in EMEs have potentially five tools to manage capital flows and mitigate any untoward consequences: monetary (interest rate) policy; fiscal policy; exchange rate policy; prudential measures; and capital controls. In deploying these tools, there is a logical reasoning (or "natural mapping") between instruments and risks (Blanchard et al., 2014). Thus, monetary and fiscal policies can help to address the inflation and economic overheating concerns raised by capital inflows; when the currency is not undervalued, foreign exchange (FX) intervention can be used to limit currency appreciation that threatens competitiveness; and prudential measures can be applied to curb excessive credit growth and related financial-stability risks. Capital inflow controls, if applied sufficiently broadly, can buttress these other policies by limiting the volume of capital inflows in the first place, or more targeted controls can be used to address balance sheet vulnerabilities such as currency and maturity mismatches. Countries with controls on capital outflows can also relax these restrictions to lower the volume of net flows, thus reducing overheating and currency appreciation pressures.

Despite this logic, there is surprisingly little formal evidence that EMEs actually respond this way - or indeed, that they respond at all. For instance, though not explicitly looking at capital flows, Eichengreen and Rose (2014) and Fernandez et al. (2015) claim that capital controls tend to be highly persistent, and do not vary in response to economic and financial cycles. Végh and Vuletin (2012) and McGettigan et al. (2013) show that monetary policy in many EMEs tends to be procyclical relative to output, while Talvi and Végh (2005), Kaminsky et al. (2005) and Ilzetzki and Végh (2008) note that fiscal policy in emerging markets is also

\footnotetext{
${ }^{1}$ See, for example, IMF (2005) and de Rato (2007). IMF (2005) reports that during the 1990s, the IMF staff gave advice on managing capital inflows to 16 EMEs (out of a sample of 27 EMEs), covering 19 episodes of large inflows. Of those 19 cases, EMEs were explicitly advised to tighten fiscal policy in 12 cases; allow greater exchange rate flexibility in 14 cases; tighten monetary policy in 4 cases; sterilize intervention in 9 cases; liberalize capital outflows in 6 cases; tighten prudential measures in 4 cases; and tighten inflow controls in 2 cases.
} 
highly procyclical. Given that capital inflows to EMEs are typically expansionary, this implies that policy is either not responding to them, or doing so in a perverse direction. ${ }^{2}$

There are several reasons why the literature to date may have been unable to identify a systematic policy response by EMEs to capital flows. First, existing studies generally confine their analysis to a single policy instrument (monetary, fiscal, or capital controls). It is quite plausible, however, that political or structural constraints prevent the use of specific instruments in some EMEs, so a more general statement about whether policies respond to capital flows cannot be made by looking at one instrument alone. Second, most studies are based on broad and heterogeneous samples of countries (co-mingling middle-income EMEs with high-income advanced economies or low-income developing countries), and spanning long periods of time. Yet, the challenges that capital flows pose to EMEs are often quite different from those they pose to advanced or developing economies. Moreover, it is only in recent years that most EMEs have liberalized their capital account sufficiently that large flows can pose macroeconomic and financial-stability risks that necessitate a policy response. Third, much of the evidence is based on annual data, but policy may move in offsetting directions within the year in response to changes in capital flows - thus obscuring the response in the data. For studies analyzing capital controls, an additional concern is that they use slow-moving indices reflecting the presence of restrictions rather than the cyclical variations in the intensity of restrictions. This is a crucial distinction since most responses to capital flows involve increasing or decreasing the intensity of existing measures, rather than imposing new restrictions or eliminating them entirely. Indices based on the presence of restrictions may thus fail to adequately capture the response of EMEs to capital flows.

In this paper, we address these issues by examining systematically how EME policy makers respond to capital inflows across the whole gamut of instruments - monetary policy, fiscal policy, exchange rate policy, prudential measures, and capital controls (on both inflows and outflows) - that are potentially available. For our analysis, we use quarterly data for a sample of about 50 EMEs over 2005-13 - a period when capital flows to EMEs have been particularly volatile, and the debate on how to manage them has been especially vigorous in both policy and academic circles. In addition, to examine the response of capital controls and prudential policies, we combine existing and novel databases to compile change-based measures that better capture the higher frequency intensification and relaxation of policies.

Going beyond existing studies, we also examine whether the policy response differs across the type of capital flows - that is, net vs. "gross" (asset and liability) flows; and within net flows, across foreign direct investment (FDI), portfolio, and other investment flows - and whether there is a broad alignment between the choice of policy instrument and the nature of the risk posed by flows, as implied by the natural mapping discussed above. Moreover, we examine whether the policy response is broader (in the sense of multiple instruments being

\footnotetext{
${ }^{2}$ These conclusions seem at odds with anecdotal evidence, which shows that EMEs do try to manage capital inflows, with some making active use of a variety of instruments (see, e.g., Kawai and Lamberte, 2010; Carrasco et al., 2014).
} 
deployed) when inflows surge - presumably because of greater macroeconomic and financial-stability risks - than under more normal flows. ${ }^{3}$

Our findings show that EMEs do respond to capital inflows using a combination of policy instruments - both macroeconomic tools and less orthodox measures. In the face of net capital inflows, central banks raise policy interest rates to address inflation and overheating concerns; controlling for these, they tend to lower interest rates to reduce currency appreciation pressures. Most central banks also intervene heavily, on average buying some 30-40 percent of capital inflows. Fiscal policy, however, is nearly always neutral or procyclical, with almost no evidence of tightening in the face of capital inflows. Some EMEs tighten (non-discriminatory) prudential measures, as well as capital controls (including currency-based prudential measures that affect capital inflows); those with relatively closed capital accounts also relax outflow restrictions to reduce net inflow pressures.

The policy response differs according to the type of capital flows. The policy rate, for instance, responds more to liability (nonresident) flows than to asset (domestic resident) flows, and among the various types of flows, more to FDI than to other types of flows (perhaps because FDI inflows tend to be more expansionary; Blanchard et al. 2015, 2016; Ghosh and Qureshi, 2016a). Similarly, central banks intervene more in the face of portfolio inflows as compared to other flows. In general, EMEs use prudential measures and inflow controls in the face of riskier forms of inflows, with some correspondence between the type of measure and the type of flow. Thus, macroprudential tools (such as reserve requirements; loan-to-value and debt-to-income ratios), controls on bond inflows, and currency-based prudential measures respond more to portfolio and other investment flows than to FDI. This policy response makes intuitive sense inasmuch as these types of flows are more prone to generating financial-stability concerns (Ghosh and Qureshi, 2016a).

Overall, policies are more likely to respond (and a larger number of tools deployed) during inflow surges than in more normal times. Moreover, there is some correspondence between the "natural mapping" and the actual use of policy instruments - thus, we find that central banks are more likely to intervene when the real exchange rate is appreciating; more likely to tighten monetary policy when the economy is overheating; and more likely to use macroprudential tools when financial-stability concerns dominate. Inflow controls are more likely to be used when policy makers are contending with multiple imbalances - specifically, when the currency is appreciating and there are financial-stability concerns.

The rest of the paper is organized as follows. Section II introduces the data, and provides some stylized facts on policy response to capital flows in our sample of countries. Section III examines empirically how macroeconomic (monetary, fiscal, and exchange rate) policies

\footnotetext{
${ }^{3}$ We focus on capital inflows here because much of the policy advice to EMEs in recent years has been about managing inflows, given increasing evidence that how the inflow phase is managed has an important bearing on whether it ends smoothly or in a crisis (see, e.g., Ghosh, Ostry, and Qureshi, 2016). Moreover, large capital outflow cases mostly represent crisis or near-crisis situations, where policy advice tends to take into account a broader set of considerations (e.g., the amount/nature of foreign liabilities, debt restructuring prospects, etc.), and is therefore much more idiosyncratic.
} 
respond to capital inflows, while Section IV turns to the less orthodox part of the toolkitprudential measures and capital controls - to see whether these instruments are used systematically in the face of inflows. Section V presents observations on whether, consistent with the natural mapping, there is a broad correspondence between the choice of the policy tool and the risks posed by capital inflows. Section VI looks more specifically at policy responses in the face of inflow surges. Section VII concludes.

\section{DATA AND StYlized FACTS}

We examine the policy response of emerging markets to capital inflows by compiling quarterly data for a sample of 51 EMEs over 2005-2013 from multiple sources. ${ }^{4}$ For macroeconomic variables, we obtain most of our data from the IMF's International Financial Statistics and World Economic Outlook databases. For macroprudential measures and capital controls, getting relevant data is however a less straightforward process as these tend to be administrative measures that are neither easily quantifiable nor comparable across countries. Most available indices are thus rather crude - indicating the presence of restrictions, not their intensity - and typically failing to pick up the cyclical variations (tightening or easing) in the intensity of measures (e.g., Chinn and Ito, 2006; Schindler, 2009; Ostry et al., 2012; Cerutti et al., 2015).

To capture variations in the intensity of prudential and capital control measures, we compile data on changes in these measures to indicate whether the measures have been tightened or eased. For macroprudential measures, we rely on Akinci and Olmstead-Rumsey (2015) who provide information on changes in seven different types of measures - countercyclical capital requirements; dynamic loan loss provisioning; caps on loan-to-value (LTV) and debt-toincome (DTI) ratios; and limits on credit growth and consumer loans-for 27 EMEs in our sample. Using this information, we construct binary variables that indicate the tightening of individual policies (with +1 coded as tightening, and zero otherwise), as well as an overall measure that reflects the tightening of any type of macroprudential policy.

In addition to the binary variables, we also use a continuous measure of legal reserve requirements (RRs) on local currency liabilities, developed by Federico et al. (2014). This measure is available (at quarterly frequency) for 35 EMEs in our sample, and being directly quantifiable, has the advantage of capturing the intensity of macroprudential policy across countries, as well as the extent of any changes to it. ${ }^{5}$

For capital controls, we use quarterly data compiled by Ahmed et al. (2015), which records changes in (residency-based) capital inflow controls along with changes in foreign currency-

\footnotetext{
${ }^{4}$ EMEs are identified as countries included currently (or until recently) in the IMF's Vulnerability Exercise for Emerging Markets. Sample composition varies across estimations depending on data availability (see appendix, Tables A.1 and A.2 for details). The estimation results presented below, however, remain very similar if a consistent (but smaller) sample of countries for which data is available on all policy measures is used.

${ }^{5}$ While the earlier conception of RRs was that of a monetary policy tool, in recent years they have been used increasingly from a macroprudential perspective as well (Cordella et al., 2014).
} 
related prudential measures that may act like inflow controls. ${ }^{6}$ Although this data is available for only 17 EMEs in our sample, these countries are the major recipients of capital inflows (collectively receiving over 65 percent of total flows to EMEs). Using this data, we create binary measures indicating the tightening of controls on different types of flows such as equity, bond, and bank flows (with a tightening coded as +1 , and zero otherwise), and an overall binary measure to indicate whether any type of capital control was tightened.

We create similar measures for capital outflow controls - documenting changes in restrictions pertaining to equity, bond, and bank outflow in the same set of 17 EMEs - using information from the IMF's Annual Report on Exchange Arrangements and Exchange Restrictions (AREAER). However, instead of recording the tightening of restrictions, we focus on their relaxation as policy makers are likely to lower the barriers to outflows when confronted by an inflow surge. Thus, we create binary measures of the easing of controls on different types of outflows (with easing coded as +1 , and zero otherwise), and an overall binary measure to indicate whether any type of capital control was relaxed over 2005-13.

\section{A. Capital Flows and Responses}

A first look at our data suggests that capital flows to EMEs have been quite volatile over the sample period (Figure 1[a]). Net flows to EMEs more than doubled from USD 73 billion in 2005Q1 to about USD 180 billion in 2007Q2, before reversing sharply in 2008Q4 when these countries collectively experienced net capital outflows of some USD 185 billion. Inflows rebounded quickly after the global financial crisis on the back of accommodative monetary policies in advanced countries, rising to USD 260 billion in 2011Q2, but fell again sharply only two quarters later after the sovereign debt downgrade of the United States and the accompanying increase in global risk aversion. Swings in capital flows to EMEs have continued since then as global and domestic economic conditions have evolved, but the volatility seems to be the most pronounced for other investment flows, followed by portfolio flows, while FDI flows have remained relatively stable (Figure 1[b]).

Emerging market central banks have not been indifferent to this volatility in capital flows. FX intervention - defined here as a change in foreign reserve assets (excluding valuation changes) scaled by GDP - follows the ebbs and flows of capital, with a strong correspondence between reserve accumulation and net flows (Figure 2[a]). For the policy interest rate, the pattern is less clear, with the raw correlation between net capital flows to EMEs and the average policy rate suggesting some counter-cyclicality (that is, the policy rate increases during periods of inflows and decreases during reversals), but that is statistically insignificant. Fiscal policy_proxied by the (cyclical component of) real government

\footnotetext{
${ }^{6}$ We consider residency-based capital controls and currency-based prudential measures together, as both are likely to deter the cross-border movement of capital, even if that is not the design intent of the latter (Ostry et al., 2011, 2012; IMF, 2012). IMF (2012) uses the terminology of capital flow management measures (CFMs) for these measures; the classification of a particular measure as a CFM, however, requires an assessment of the country-specific circumstances and a "judgment as to whether the measure is, in fact, designed to limit capital flows." To ensure consistency in treatment of measures across countries, and to avoid exercising subjective judgment, we refrain from using the CFM terminology here.
} 
consumption expenditure following existing studies (e.g., Kaminsky et al., 2005; Ilzetzki and Végh, 2008; Frankel, Végh, and Vulletin, 2013) — shows no discernible relationship with net capital flows, with the unconditional correlation between the two series being slightly negative but statistically insignificant (Figure 2[b]).

Turning to the less orthodox part of the policy toolkit, a simple snapshot of changes in macroprudential policies suggests that both the number of countries tightening policies, as well as the total number of measures that are tightened (net of easing) across countries is positively correlated with net capital flows (Figure 3[a]). Thus, countries tighten prudential policies as inflows surge, and relax them when flows abate or reverse. Importantly, this correlation appears to have become more pronounced since the global financial crisis, indicating increased reliance on prudential policies by EMEs in recent years to mitigate the financial-stability risks associated with inflows (see appendix; Table A.3). A similar picture emerges when reserve requirements are considered: the number of countries raising RRs, and the average RR across countries, track closely swings in net capital flows (Figure 3[b]).

The use of capital controls and currency-based prudential measures across EMEs has not been very uncommon either: the tightening (net of easing) of such measures corresponds closely with the capital flows received by EMEs (Figure 3[a]). Looking across countries, 11 (of the 17 countries in the sample) tightened inflow controls and related measures over the sample period (Table A.4). Brazil has perhaps been the most active country in terms of calibrating its controls to inflows, but other countries such as Indonesia, Korea, and Turkey have also tightened restrictions on inflows in recent years, especially on cross-border bank flows. Among the different types of asset categories, restrictions targeting bank flows (directly, or indirectly through currency-based prudential measures) are the most common, followed by those on bond flows - suggesting that the motive for these controls may have been mainly to mitigate financial-stability risks.

Looking at (the easing of) outflow controls, the picture is quite similar: both the number of countries relaxing restrictions, and the total number of measures eased (net of measures tightened) corresponds to capital inflows (Figure 3[b]). It is, however, important to note that the countries relaxing restrictions on outflows in the face of net capital inflows are those with partially liberalized capital accounts (e.g., India and South Africa). For EMEs with largely open capital accounts (such as Mexico and Romania), the policy option of further relaxing outflow controls may not be available.

In sum, the initial snapshots presented here support the notion that EME policy makers do react to capital flows. In what follows, we examine formally through regression analysis how macroeconomic (monetary, fiscal, exchange rate), macroprudential, and capital control policies respond to flows, and to what extent that response depends on the type of inflow. 


\section{Macroeconomic Policy Response}

\section{A. Response to Net Capital Flows}

We begin by analyzing the response of exchange rate, monetary, and fiscal policies to aggregate net capital flows in EMEs, and estimate the following equation:

$$
Y_{i t}=\alpha+\beta K F_{i t}+\sum_{j=1}^{J} \delta_{j} Z_{j t}+\sum_{k=1}^{K} \gamma_{k} X_{k i t}+\mu_{i}+\varepsilon_{i t}
$$

where $Y$ represents the macroeconomic policy response (FX intervention, central bank policy rate, or real government consumption expenditure) in country $i$ in period $t ; K F$ is net capital flows (in percent of GDP); $Z$ are the global factors (such as global market uncertainty proxied by the VIX index, commodity prices, U.S. real interest rates) that may influence the policy response of EMEs through channels other than capital flows; $X$ reflects relevant domestic control variables (such as the output gap, inflation, currency appreciation, etc.); $\mu_{\mathrm{i}}$ are time-invariant country-specific effects; $\beta, \gamma$, and $\delta$ are the parameters to be estimated; and $\alpha$ and $\varepsilon$ are the constant and random error terms, respectively. To capture any seasonal effects in the policy response variables, we also include quarter-specific effects in (1), together with a binary variable for the global financial crisis to control for any extraordinary policy response during the crisis.

We estimate (1) using the ordinary least squares method, and cluster the standard errors at the country level to account for possible serial correlation in the error term. If policy makers in EMEs respond to capital flows to tame their consequences (e.g., overheating; currency appreciation), then the estimated $\beta$ in (1) should be statistically significant and positive for FX intervention and the policy rate, but negative for government consumption expenditure (thereby indicating reserve accumulation, and counter-cyclical monetary and fiscal policies).

\section{FX intervention}

Estimating (1) for FX intervention, the results show that net capital inflows are strongly associated with reserve accumulation (Table 1, col. [1]). On average, EME central banks purchase some 40 percent of the inflow, but there is significant variation across individual countries (Table A.5). ${ }^{7}$ Asian central banks generally intervene heavily, as do some central banks in emerging Europe (notably, Czech Republic, Hungary, and Russia). Among the major Latin American countries in the sample, Mexico appears to undertake the least intervention, while Brazil and Peru intervene more heavily. Across other regions, South Africa allows the exchange rate to respond more freely to capital flows, while Jordan and Morocco intervene substantially. These findings resonate with existing surveys of emerging

\footnotetext{
${ }^{7}$ The extent to which this reserve accumulation is sterilized may be gauged by regressing the change in broad money, measured in percent of GDP, on capital inflows or on the change in reserves (also measured in percent of GDP). The resulting coefficients (not reported here) are very small, suggesting that much of the impact of the reserve accumulation on monetary aggregates is sterilized.
} 
market central banks, which document that most intervene frequently in currency markets to stabilize the exchange rate (Mihaljek, 2005; Mohanty and Berger, 2013).

Beyond the effect of capital flows, higher commodity prices are, on average, associated with sales of reserves - presumably as the central bank tries to offset the effects of the terms of trade shock (since most EMEs in our sample are commodity importers). In addition, the coefficient on the dummy variable for the global financial crisis (GFC) is negative, indicating that EME central banks sold reserves during the crisis in the face of fleeing capital and depreciation pressures. (In general, if the data is segmented into net capital inflow and outflow observations, we obtain a larger coefficient for outflow episodes relative to inflows, suggesting a stronger response during outflows; Table 2, cols. [1]-[2]).

A potential concern with these estimates is that capital flows may be responding to FX intervention, in which case the estimated coefficient would be subject to endogeneity bias (with the bias going in favor of finding a spurious positive coefficient). To address this concern, we follow recent literature (e.g., Blanchard et al., 2015; Ghosh and Qureshi, 2016a), and apply the two-stage least squares instrumental variable methodology-instrumenting net capital flows with net flows to other EMEs in the region (in percent of regional GDP). This, however, makes little difference to the results: the coefficient for net capital flows in the FX intervention regression remains positive and statistically significant-suggesting that, on average, EME central banks purchase some 30 percent of the inflow (Table 1, col. [2]).

\section{Policy interest rate}

Turning to the central bank policy rate, the regression results show that capital inflows tend to elicit higher policy rates in EMEs, with the effect statistically significant at the 5 percent level (Table 1, col. [3]). An increase in net flows by 10 percent of GDP, on average, raises the policy rate by 10 basis points. Inasmuch as inflows are usually expansionary and inflationary, this implies that the policy rate is typically used counter-cyclically, as an inflation-targeting framework would imply. Yet looking at (selected) individual country policy response functions, it is apparent that many of the estimated coefficients are negative but statistically insignificant (though all of the statistically significant coefficients are positive; Table A.6). This diversity is not surprising: where the inflows are not especially expansionary, or if inflation is not a concern, the policy rate need not be raised (and may be lowered to reduce the incentive for capital to flow into the country). Segmenting the sample into net inflow versus outflow episodes shows that the policy rate responds systematically (with a positive coefficient) to inflows but not to outflows (Table 2, cols. [3]-[4]).

Whatever impact capital flows have on the policy interest rate comes through the behavior of inflation, the output gap, or the real exchange rate. In Table 1 (col. [4]), we augment the specification with these three variables, and find that policy rates are raised in response to higher inflation or a larger output gap (i.e., GDP above potential), but tend to be lowered in response to real exchange rate appreciation (the latter effect being marginally statistically insignificant in the full sample). Adding these variables renders the coefficient on capital 
flows utterly insignificant in the panel specification, as well as in the vast majority of individual country regressions (Table A.7). Thus, with capital inflows generally being expansionary, the central bank tightens monetary policy to offset overheating of the economy; given inflation and the output gap, however, the central bank tends to lower the policy rate in the face of real exchange rate appreciation.

Among other factors, the policy rate responds positively to higher commodity prices and to US interest rates, but also exhibits a high degree of persistence (reflected by the estimated coefficient of the lagged policy rate term). ${ }^{8}$ Including a dummy variable for the GFC shows that, controlling for other factors, policy rates were on average lowered during the crisis. Addressing potential endogeneity concerns, and instrumenting capital flows with net flows to other EMEs in the region implies an increase in the policy rate by about 30 basis points for a 10 percent of GDP increase in net capital flows (col. [5]). Like the estimates reported in col. [4], the effect becomes much smaller and loses statistical significance when output gap, inflation, and change in real exchange rate are included in the model (col. [6]).

\section{Fiscal policy}

The results suggest that EME central banks respond to capital flows through both exchange rate and monetary policies (the latter depending on the cyclical position of the economy). The same, however, does not hold for fiscal policy: estimates reported in Table 1 show that net capital flows are in fact positively associated with real government consumption spending (col. [7]) - fiscal policy is thus procyclical in the face of capital inflows. Controlling for output gap and real exchange rate in col. (8), however, renders the coefficient on net capital flows statistically insignificant, implying that much of the procyclicality in government consumption spending is a response to the expansion in output associated with capital flows. This remains true even after instrumenting for net capital flows with total net flows to other EMEs in the region, and we find no evidence of systematic tightening in fiscal policy in response to capital flows (cols. [9]-[10]). ${ }^{9}$

Splitting the sample into positive and negative net flows renders further support for procyclical behavior of fiscal policy: the coefficient on net flows is positive for inflow episodes, but negative (albeit statistically insignificant) for outflow episodes (Table 2, cols. [5]-[6]). Looking at individual countries, fiscal policy seems to be strongly countercyclical in Chile - though controlling for output gap, the association between net flows and real government consumption spending is positive in that case as well (Table A.8). For most other countries, the coefficient on both net capital flows and output gap is statistically insignificant.

\footnotetext{
${ }^{8}$ The fixed effects estimation of models with lagged dependent variable can produce biased estimates (the so-called "Nickell bias"). The bias (equal to $1 / T$ ) is serious for short panels, but disappears as $T \rightarrow \infty$ (for our sample, $T=36$; so the fixed effects estimator is likely to perform at least as well as many alternatives; Judson and Owen, 1999).

${ }^{9}$ As in most other studies, we use real government spending as a proxy for fiscal policy since it is less likely to be directly endogenous to the cycle than, e.g., the fiscal balance (Kaminsky et al., 2005). Using the structural balance (available at annual frequency) likewise yields either a positive or statistically insignificant coefficient on capital flows (results available upon request).
} 
Although the orthodox policy prescription in the face of capital inflows is to tighten fiscal policy, the lack of fiscal response is hardly surprising considering that for most countries, fiscal levers take time to pull, budgets have their own cycle, and the process may be politically fraught. ${ }^{10}$

\section{B. Response by Type of Flow}

A growing body of literature shows that the properties of capital flows may differ based on the residency of the investor (domestic resident vs. nonresident), and the type of flow (FDI, portfolio, other investment). Foreign investors, for example, may be more fickle than domestic investors (Ghosh et al., 2014); equity flows may be more expansionary than debt flows (e.g., Blanchard et al., 2015); while debt flows may be more prone to generating currency overvaluation and financial vulnerability concerns than equity flows (Ghosh and Qureshi, 2016a). Does the macroeconomic policy response take into account these different consequences of flows, and vary by the type of flow?

Breaking down the net capital flow variable in (1) into asset (i.e., resident-driven) flows and liability (i.e., nonresident-driven) flows, the response in terms of FX intervention seems to be symmetric to both - with the central bank, on average, purchasing some 40 percent of the inflow regardless of its source (Table 3, col. [1]). Looking at FDI, portfolio and other investment flows, central banks appear to intervene in the face of all types of flows-but they intervene most heavily for portfolio flows, followed by other investment flows (col. [2]). These findings make intuitive sense since, as documented in recent literature, both asset and liability flows are about equally likely to induce a currency overvaluation, while debt flows are the most prone to causing currency overvaluation.

Turning to monetary policy, we find that the policy rate reacts more strongly to liability flows than to asset flows (Table 3, col. [3]). This may be because, on a net basis, large flows in EMEs tend to be driven by foreign investors, while retrenchment by domestic residents in many cases happens when the economy is experiencing a negative shock (and the policy rate needs to be lowered). ${ }^{11}$ Disaggregating flows by asset type, the policy rate reacts more strongly to FDI than to other types of flows (col. [4]). A 10 percent of GDP increase in net FDI flows, for example, raises the policy rate by some 30 basis points, while a similar increase in net portfolio or other investment flows has —on average - no significant impact on the policy rate. Inasmuch as FDI tends to be more expansionary than portfolio debt flows (Blanchard et al., 2015), this finding makes intuitive sense as policy makers try to cool down the overheating economy by tightening monetary policy. This conclusion is reaffirmed when the output gap, real exchange rate appreciation, and inflation are added to the specification, as their inclusion in the model renders the estimated coefficient on the flow variables wholly statistically insignificant (cols. [5]-[6]).

\footnotetext{
${ }^{10}$ In a broad sample of developing and emerging market countries, Frankel, Végh, and Vuletin (2013) find a strong role of institutional quality in pursuing counter-cyclical fiscal policy. In our more homogeneous sample of countries, however, we do not find institutional quality to be a significant determinant of real government spending.

${ }^{11}$ In the sample, e.g., the correlation between net and asset flows (in percent of GDP) is only 0.2 , while that between net flows and liability flows is 0.7 . Also, the mean net capital flow is significantly larger (about 6 percent of GDP) when liability flows are positive relative to when asset flows are positive (about -0.7 percent of GDP).
} 
In contrast to exchange rate and monetary policies, fiscal policy appears to be more procyclical. The coefficient on both asset and liability flows is positive and statistically significant (Table 3, col. [7]); though it turns insignificant when output gap is included in the specification (col. [8]). Similar results are obtained when we consider the different types of flows, with government spending being positively associated with portfolio and other investment flows, but not with FDI flows (cols. [9]-[10]). ${ }^{12}$

\section{UnORTHODOX MEASURES}

The results presented above suggest that policy makers indeed use macroeconomic policies - especially, monetary and exchange rate policies - systematically to respond to capital flows. But what about the less orthodox part of the policy toolkit, i.e., macroprudential measures and capital controls? To analyze the response of these policies to capital flows, we estimate the following probit model:

$\operatorname{Pr}(\text { Policy change }=1)_{i t}=F\left(\alpha+\beta K F_{i t}+\sum_{j=1}^{J} \delta_{j} Z_{j t}+\sum_{k=1}^{K} \gamma_{k} X_{k i t}+\mu_{i}\right)$

where Policy change is a binary variable with one indicating tightening of prudential measures and capital inflow controls, and relaxation of outflow controls, in successive estimations. The definition of all other variables remains the same as above..$^{13}$

\section{A. Macroprudential Measures}

Estimating (2) confirms that macroprudential policies are tightened when capital flows surge. Thus, against an unconditional tightening probability of 7.5 percent, a 10 percent of GDP increase in net capital flows raises the likelihood that macroprudential policy will be tightened by about 0.3 percentage points (Table 4 ). The association with capital flows, however, varies across the measures - limits on DTI and LTV ratios, as well as RRs, react strongly to capital inflows (cols. [7]-[9]), while the coefficient on other measures is positive but statistically insignificant (cols. [3]-[6]). For reserve requirements, the regression estimates suggest that (controlling for the initial level of RR) a 10 percent of GDP increase in net flows in EMEs typically elicits a 0.1 percentage point increase in RRs.

These results are reinforced if we apply the instrumental variable approach to address potential endogeneity concerns, and as before, instrument net capital flows with net capital flows to other EMEs in the region (in percent of regional GDP). The coefficients on both the overall macroprudential policy measure and RRs increase in magnitude, and remain statistically significant (cols. [2], [10]). Inasmuch as the use of these measures is likely to

\footnotetext{
12 To the extent that portfolio and other investment flows may also finance government consumption spending, the positive coefficient on these variables may be a result of reverse causality. Instrumenting these flows with flows to the region (in percent of regional GDP), the coefficients remain positive but turn statistically insignificant.

${ }^{13}$ For changes in reserve requirements, which is a continuous variable, we estimate the model with OLS.
} 
deter inflows - leading to a spurious negative correlation - it makes intuitive sense that controlling for endogeneity would increase the estimated positive coefficients.

Among individual countries, capital flows generally elicit tightening of macroprudential policies, though the association is statistically significant only for Croatia, Indonesia, and Korea (Table A.9). Similarly, RRs respond positively to capital inflows in most countries, but the coefficient is statistically significant for Brazil, Turkey, and Uruguay.

Looking at the various types of flows, the results reported in Table 5 show that policy makers respond to both asset and liability flows (although for the overall macroprudential indicator, only the response to liability flows is statistically significant; col. [1]). The macroprudential response is, however, stronger for portfolio and other investment flows (which are mainly bank flows) as compared to FDI (cols [2], [4], [6], and [8]). Since, as mentioned above, portfolio and other investment flows tend to be the most prone to causing domestic credit booms and financial-stability risks, it is intuitive that policy makers would react more aggressively to them using macroprudential tools.

\section{B. Capital Controls}

Turning to capital controls, the results obtained from the probit model (where in addition to other variables, we control for institutional quality which is often considered to be an important determinant of capital controls) confirm that EMEs do respond to capital inflows by tightening inflow controls (Table 6, col. [1]). ${ }^{14}$ Against an unconditional probability of 8 percent in the full sample, the predicted probability of tightening inflow controls increases by about 0.3 percentage points if net flows are 10 percentage points higher around the mean value (of 3.7 percent of GDP in the estimation sample). The result hold - in fact are strengthened - if we instrument net capital flows with net flows to the region to address potential endogneity concerns (which would tend to downward bias the coefficient on capital flows): the coefficient on capital flows almost doubles in magnitude and remains highly statistically significant (col. [2]).

Among individual countries that imposed or tightened inflow controls, the policy action is statistically significantly associated with net capital inflows in Brazil, India, Philippines, and Turkey (Table A.10). Moreover, disaggregating by the type of flow, it is apparent that countries tighten controls in the face of portfolio and other investment inflows (Table 7). This suggests that there may be a prudential motive behind tightening capital controls. There also appears to be some mapping between the tightening of specific types of controls (equity, bond, and financial-sector related), and the nature of the inflow (Table 7, cols. [3]-[5]). Bond

\footnotetext{
${ }^{14}$ The results remain similar if additional control variables such as domestic real GDP growth, and a measure of overall capital account openness are included in the model.
} 
controls thus respond strongly to net portfolio flows, while financial sector-related restrictions react to both portfolio and other investment liability flows. ${ }^{15}$

For outflow controls, results from the probit model suggest that the probability of relaxing restrictions is also higher when net flows surge; and this result is strengthened when we address endogeneity concerns by instrumenting for net capital flows (Table 6, cols. [3]-[4]). The likelihood of such an action is, however, greater in the face of liability flows, especially for other investment flows (Table 7, cols. [6]-[10]).

These results for capital controls are in contrast to the findings of other recent studies (Eichengreen and Rose, 2014; Fernandez et al., 2015), who argue that capital controls are acyclical and do not respond to macroeconomic activity. There are several possible reasons why our results depart from theirs. First, as mentioned earlier, these studies use slow-moving capital account openness indices based on the presence of restrictions instead of measures reflecting changes in capital controls. While their indices may capture broad trends in liberalization, they are likely to overlook the finer, higher frequency variations in capital account restrictions (e.g., if the tax rate on inflows is increased from 10 percent to 20 percent, the change will not be reflected in the indices they use; by contrast, the increase would be captured in our change-based measures). Second, we consider residency-based capital controls together with currency-based prudential measures; both are likely to deter capital flows, and EMEs have been increasingly relying on the latter to mitigate financial-stability risks associated with capital inflows (Ostry et al., 2012; Ghosh and Qureshi, 2016b). Third, existing studies analyze the behavior of capital controls against several macroeconomic indicators (such as real GDP growth, exchange rate, domestic credit growth, etc.), while we look at their link with capital flows directly. (Macroeconomic indicators may move independently of capital flows - in which case there is no reason to use capital controls.) Finally, in contrast to other studies, we consider a more recent time period in our analysis when cross-border capital flows have been particularly volatile necessitating a policy response, and focus on a more homogeneous sample of (emerging market) countries for which capital flow volatility has been particularly challenging. (Advanced economies are in any case generally prohibited from imposing capital controls and prudential measures that may act as capital controls by virtue of their OECD/EU membership.)

The overall existence of capital controls may be persistent, but our findings suggest that, along with exchange rate and monetary policies, several major emerging markets have varied the intensity of capital controls and currency-based prudential measures to deal with capital inflows - especially, those flows that are prone to creating financial-stability risks.

\footnotetext{
15 The results for different types of inflow control should be interpreted with caution since for equity and bond controls, there are few instances of tightening in the sample (Table A.10).
} 


\section{NATURAL MAPPING}

Evidently, emerging market policy makers do respond to capital inflows through various tools. The "natural mapping" discussed earlier, however, suggests that the choice of instrument should depend on the macroeconomic challenge or financial-stability risk posed by the inflow. Thus, monetary policy should be tightened in the face of inflation and economic overheating concerns; FX intervention should be used to stem currency appreciation; macroprudential measures to curb credit growth; and inflow controls (or relaxation of outflow controls) to buttress these other policies by limiting the volume of inflows or to target specific risky flows. To see if this is indeed the case, this section presents some stylized facts to illustrate the extent to which policy makers follow this mapping.

We begin with FX intervention. From Figure 5[a], when FX intervention is used (i.e., reserves are accumulated), the real exchange rate is appreciating by an average of 3 percent per year, as opposed to depreciating by an average of about 2 percent per year when intervention is not used-implying a (statistically significant) 5 percentage point difference in real appreciation between times that intervention is used and when it is not. ${ }^{16}$ This may be contrasted to monetary policy, which is also used in the face of capital inflows, but the real appreciation when monetary policy rate is tightened does not differ significantly from the appreciation when monetary policy is not used. While the real exchange rate is appreciating when macroprudential measures are used, the differential is smaller (about 2 percentage points) and weakly statistically significant. By contrast, the real appreciation when inflow controls are deployed is 6 percent per year compared to 1 percent per year when controls are not used, and this differential is strongly significant. This suggests that, consistent with the natural mapping, FX intervention is the instrument of choice in the face of real currency appreciation - buttressed by the use of inflow controls for especially large appreciation.

What matters for the use of monetary policy is the output gap, which is significantly larger when monetary policy is tightened compared to periods in which monetary policy is not (Figure $5[\mathrm{~b}]$ ). Also relevant to the use of monetary policy is the rate of domestic credit growth, which is significantly faster in periods when monetary policy is tightened than when it is not. The output gap seems to be largely irrelevant to the decision to deploy other instruments (for FX intervention, the differential is statistically significant at the 10 percent level but very small in magnitude). Thus, as the natural mapping would imply, policy makers choose to tighten monetary policy in the face of economic overheating concerns (positive output gap, and rapid credit growth that may be fueling inflationary concerns).

Macroprudential measures (including increases in reserve requirements) are typically deployed in the face of rapid credit growth, with the difference in credit growth between periods in which prudential measures are used and periods in which they are not, is statistically significant (and somewhat larger than the differential for monetary tightening; Figure $5[\mathrm{c}])$. To a lesser degree, macroprudential measures are used in the face of currency

\footnotetext{
${ }^{16}$ Instruments are said to have been used if they were deployed in a specific quarter. Sample comprises observations for which data is available on all policy measures (policy rate; FX intervention; prudential measures; capital controls).
} 
appreciation, though as noted above, the difference in the rate of appreciation is smaller than the difference relevant to the use of FX intervention.

Comparing periods in which inflow controls are tightened to those in which they are not, shows that the former are characterized by (statistically significantly) faster credit growth and currency appreciation, but not a larger output gap (Figure 5[d]). In fact, on average, REER appreciation is 5 percentage points greater when both inflow controls and FX intervention are used, as compared to when FX intervention is used alone; similarly, credit expansion is about 2 percentage points faster when both inflow controls and macroprudential measures are tightened, than when the latter are deployed alone. Moreover, in virtually all of the cases in the sample, inflow controls are used with at least one other instrument. These observations suggest that capital controls are deployed when countries are contending with multiple, and increased, risks that threaten financial and macroeconomic stability.

Finally, for outflow controls, Figure 5[e] shows that in cases where they are used, output gap and currency appreciation are higher than when they are not used, but the difference between the two groups is statistically insignificant. Overall, as shown in Figure 5[f], multiple instruments are deployed when multiple risks emerge.

These suggestive observations are confirmed when we estimate formal probit models for the use of policy instruments considering macroeconomic and financial-stability risks (credit growth, output gap, currency appreciation) together as regressors, while controlling for common global factors, country-specific effects, and quarter effects (Table 8). Thus, central banks are significantly more likely to intervene when the currency is appreciating (col. [1]); raise policy rates when the economy is overheating (col. [2]); and tighten macroprudential measures when domestic credit is expanding rapidly (cols. [3]). Inflow controls are especially likely to be used in the presence of competitiveness and financial-stability concerns, while outflow controls are used to ease currency appreciation pressures (cols. [4]-[5]). ${ }^{17}$

These findings lend support to the natural mapping: currency appreciation is what is most relevant to the decision to use FX intervention; the output gap for monetary policy; credit growth for macroprudential measures; and multiple risks for the use of capital controls.

\footnotetext{
${ }^{17}$ It is worth nothing that any potential endogeneity would go against finding statistically significant coefficients since FX intervention (reserve accumulation) would tend depreciate the exchange rate, higher policy rates would tend to dampen the output gap, macroprudential measures would tend to curb credit growth, and capital controls would tend to reduce all of these - thus, biasing the corresponding coefficients in the probit model toward zero. Any effects identified are thus despite - rather than because of - any endogeneity.
} 


\section{RESPONDING TO INFLOW SURGES}

While EME policy makers respond to inflows, they do not of course adjust policies in response to every tiny wriggle in the volume of flows; instead, they are more likely to respond to large increases in flows-i.e., to surges. In this section, we round out the analysis by examining policy responses during surge episodes.

To identify inflow surge observations, we follow the "threshold" methodology commonly adopted in the literature (e.g., Reinhart and Reinhart, 2009; Ghosh et al., 2014), and define surges as those net capital flow (in percent of GDP) observations that lie in the country's top $30^{\text {th }}$ percentile of the distribution of quarterly net flows. To identify normal flow cases, we first identify large outflow observations in a symmetric way as those that fall in the bottom $30^{\text {th }}$ percentile of the distribution of quarterly net flows (in percent of GDP), and then consider all remaining observations as normal flows.

Based on our definition, we identify almost 700 surge observations occurring in 53 countries during 2005Q1-2013Q4. ${ }^{18}$ Of these observations, we have data available on all four policy measures - the policy rate, FX intervention, tightening of macroprudential measures, and capital controls - for 223 surges, occurring in Brazil, Chile, Colombia, Hungary, India, Indonesia, Korea, Malaysia, Mexico, Philippines, Poland, Romania, South Africa, Thailand, and Turkey. Correspondingly, out of a total of 674 normal flow observations, we have data available on all policy measures for 201 observations. The final data set for this section of the paper thus consists of 223 surge observations and 201 normal flow observations.

During the 223 surges, FX intervention is nearly always used - even though many of the central banks are inflation-targeters (Figure 4[a]). While emerging market central banks also intervene in the face of more normal flows, the percentage of surge observations in which they intervene (92 percent) is statistically significantly greater than the percentage of nonsurge observations in which they intervene (75 percent).

Monetary tightening is the second most common tool, occurring in about 32 percent of surges, though this is not significantly greater than the 29 percent probability of tightening in non-surge cases. Monetary loosening, however, is statistically significantly less likely during surges than in normal times. Consistent with the results reported in Table 2, the key distinguishing feature between instances when the policy rate is raised or lowered is the output gap, which is almost two percentage points smaller in the latter case.

Macroprudential policies (including reserve requirements) are the next most popular tool, tightened in about 16 percent of surges, followed by inflow controls that are tightened in 11 percent of cases, while outflow controls are relaxed in some 10 percent of surges. Of these, only the use of inflow controls is statistically significantly more likely during surges than

\footnotetext{
${ }^{18}$ To identify large inflow and outflow observations, we use quarterly data over a longer horizon of 2000-13 so that the observations are "large" by historical standards. Further, we treat any negative (positive) net capital flow observation identified as a surge (large outflow) as a normal flow.
} 
during times of normal flows. This is unsurprising inasmuch as macroprudential tools may be used in the face of domestically-driven credit booms, as well as in foreign-fueled booms.

Not only is the use of individual tools more likely in surges, so is the use of combinations of policy tools (presumably because surges result in multiple risks; Table A.12). Thus, the share of observations in which only one policy instrument is used is smaller for surges (49 percent) than it is for normal flows (51 percent). By contrast, two instruments (FX intervention, and usually - but not always - the policy interest rate) are used in 35 percent of surges relative to 27 percent of normal flow cases (a statistically significant difference), while three or more instruments are deployed in 13 percent of surges but in only 7 percent of normal flow observations (also a statistically significant difference). ${ }^{19}$

This "portfolio" approach of using multiple policy instruments makes intuitive sense when policy makers face multiple challenges from capital flows and therefore have several targets, there are (possibly convex) costs associated with the use of each instrument, and there is uncertainty about the effects of the instrument on the intended target.

\section{Conclusion}

Policy advice to emerging markets on capital flow management has evolved over the years, with growing recognition that both macroeconomic and less orthodox policies may play a useful role in mitigating the risks associated with capital flows. This paper takes a positive stance and examines how EME policy makers respond to capital flows in practice, and the extent to which they use the various policy tools (monetary and fiscal policy; FX intervention; macroprudential measures, and capital controls) at their disposal.

Our results suggest that EME policy makers typically respond through a combination of instruments to deal with capital flows. Central banks use the policy interest rate to address inflation and overheating concerns, and to a lesser degree, to reduce currency appreciation pressures. They also intervene heavily in the face of capital inflows, but tend to react more to portfolio inflows as compared to other types of flows. Although the orthodox policy prescription in the face of capital inflows is to tighten fiscal policy, we find that it is the leastused instrument in practice with no strong evidence that EMEs systematically tighten it in response to large capital flows.

Beyond macroeconomic policies, EMEs tighten non-discriminatory macroprudential measures, as well as residency and currency-based measures that affect capital inflows, while countries with relatively closed capital accounts tend to relax restrictions on capital outflows. In general, the response is stronger to riskier forms of inflows, with some mapping between the type of the measure and the nature of the inflow. Thus, macroprudential measures, inflow

\footnotetext{
${ }^{19}$ Interestingly, the use of countercyclical policy in large outflow cases is almost symmetric-with reserve decumulation, monetary and macroprudential policy easing, and outflow control tightening more likely than in normal flows (Figure A.1).
} 
controls, and currency-based prudential measures react more to portfolio flows and other investment liability (predominantly cross-border bank) flows.

There is some correspondence between the tool deployed and the nature of the risk - thus, central banks intervene when the real exchange rate is appreciating, tighten monetary policy when the economy is overheating, and use macroprudential tools when financial-stability concerns dominate, while inflow controls are typically used in the face of multiple and heightened risks. Not surprisingly, the results are even sharper in the face of inflow surges. Both the use of individual instruments and the use of combinations of policies are more likely during inflow surges than during periods of more normal flows.

Nevertheless, there are important differences in the policy behavior across countries even in similar macroeconomic circumstances, which suggests that structural, and perhaps political considerations may be at play in shaping the specific policy response. Moreover, a relevant and important question is whether the active policy management pursued by EMEs has contributed to fewer financial crises in recent years, despite the greater volatility in capital flows. We leave these issues for future research. 


\section{References}

Ahmed, S., S. Curcuru, F. Warnock, and A. Zlate, 2015, "The Two Components of International Capital Flows," mimeo, University of Virginia.

Akinci, O., and J. Olmstead-Rumsey, 2015, "How Effective are Macroprudential Policies? An Empirical Investigation,” International Finance Discussion Papers No. 1136 (Washington D.C.: Federal Reserve Board).

Blanchard, O., J. Ostry, A. Ghosh, and M. Chamon, 2014, "Dealing with Capital Inflows," Keynote remarks made at the Central Bank of Chile's conference on "The Role of Central Banks in Modern Times: Twenty-Five Years into the Central Bank of Chile's Independence," October 24, 2014, Santiago, Chile.

Blanchard, O., J. Ostry, A. Ghosh, and M. Chamon, 2015, “Are Capital Inflows Expansionary or Contractionary? Theory, Policy Implications, and Some Evidence,” NBER Working Paper 21619 (Cambridge, MA: National Bureau of Economic Research).

Blanchard, O., J. Ostry, A. Ghosh, and M. Chamon, 2016, "Capital Flows: Expansionary or Contractionary?" American Economic Review, 106(5): 565-569

Carrasco, B., H. Mukhopadhyay, and S. Gokarn, 2015, Managing Capital Flows: Issues in Selected Emerging Market Economies (New Delhi: Oxford University Press).

Cerutti, E., S. Claessens, and L. Laeven, 2015, "The Use and Effectiveness of Macroprudential Policies: New Evidence," IMF Working Paper WP/15/61.

Chinn, M., and H. Ito, 2008, "A New Measure of Financial Openness," Journal of Comparative Policy Analysis, 10 (3): 309-322.

Cordella, T., P. Federico, C. Végh, and G. Vuletin, 2014, Reserve Requirements in the Brave New Macroprudential World (Washington D.C.: World Bank).

de Rato, R., 2007, "Capital Flows in an Interconnected World," remarks made at the SEACEN Governors Conference, Bangkok, Thailand July 28, 2007.

Eichengreen, B., and A. Rose, 2014, "Capital Controls in the $21^{\text {st }}$ Century," Journal of International Money and Finance, 48: 1-16.

Federico, P., C. Végh, and G. Vuletin, 2014, "Reserve Requirement Policy over the Business Cycle,” NBER Working Paper 20612 (Cambridge, MA: NBER).

Fernández, A., A. Rebucci, and M. Uribe, 2015, “Are Capital Controls Countercyclical?” Journal of Monetary Economics, 76 (November), 1-14.

Frankel, J., C. Végh, and C. Vuletin, 2013, “On Graduation from Fiscal Procyclicality,” Journal of Development Economics, 100 (1): 32-47.

Ghosh, A., M. Qureshi, J. Kim, and J. Zalduendo, 2014, "Surges,” Journal of International Economics, 92 (2): 266-285.

Ghosh, A., J. Ostry, and M. Qureshi, 2016, "When Do Capital Inflow Surges End in Tears?" American Economic Review, 106(5): 581-585. 
Ghosh, A., and M. Qureshi, 2016a, "Capital Inflow Surges and Consequences," ADBI Working Paper No. 585 (Tokyo: Asian Development Bank Institute).

Ghosh, A., and M. Qureshi, 2016b, "What's in a Name? That Which We Call Capital Controls," IMF Working Paper WP/16/25 (Washington D.C.: International Monetary Fund).

Ilzetzki, E., and C. Végh, 2008, "Procyclical Fiscal Policy in Developing Countries: Truth or Fiction?” NBER Working Papers 14191 (Cambridge, MA: NBER).

IMF, 2005, Evaluation Report: The IMF's Approach to Capital Account Liberalization (Washington D.C.: International Monetary Fund).

IMF, 2012, The Liberalization and Management of Capital Flows: An Institutional View (Washington D.C.: International Monetary Fund).

Judson, R., and A. Owen, 1999, "Estimating Dynamic Panel Data Models: A Guide for Macroeconomists," Economic Letters, 65(1): 9-15.

Kaminsky, G., C. Reinhart, and C. Végh, 2005, "When it Rains, it Pours: Procyclical Capital Flows and Macroeconomic Policies," in NBER Macroeconomics Annual 2004, eds. M. Gertler and K. Rogoff, 19: 11-82.

Kawai, M., and M. Lamberte, 2010, Managing Capital Flows: The Search for a Framework (Tokyo and Cheltenham: ADBI and Edward Elgar).

McGettigan, D., K. Moriyama, J. Ntsama, F. Painchaud, H. Qu, and C. Steinberg, 2013, "Monetary Policy in Emerging Markets: Taming the Cycle," IMF Working Paper WP/13/96 (Washington D.C.: IMF).

Mihaljek, D., 2005, “Survey of Central Banks' Views on Effects of Intervention," BIS Papers No. 24: 82-96 (Brussels: Bank for International Settlement).

Mohanty, M., and B. Berger, 2013, "Central Bank Views on Foreign Exchange Intervention," BIS Papers No. 73: 55-74 (Brussels: Bank for International Settlement).

Ostry, J., A. Ghosh, K. Habermeier, M. Chamon, M. Qureshi, and D. Reinhardt, 2010, “Capital Inflows: The Role of Controls," IMF Staff Position Note 10/04 (Washington D.C.: IMF).

Ostry, J., A. Ghosh, K. Habermeier, L. Laeven, M. Chamon, M. Qureshi, and A. Kokenyne, 2011, "Managing Capital Inflows: What Tools to Use?” IMF Staff Discussion Note 11/06 (Washington D.C.: International Monetary Fund).

Ostry, J., A. Ghosh, M. Chamon, and M. Qureshi, 2012, “Tools for Managing Financial-Stability Risks from Capital Inflows,” Journal of International Economics, 88(2): 407-421.

Talvi, E., and C. Végh, 2005, "Tax Base Variability and Procyclical Fiscal Policy in Developing Countries," Journal of Development Economics, 78(1): 156-190.

Végh, C., and G. Vuletin, 2012, "Overcoming the Fear of Free Falling: Monetary Policy Graduation in Emerging Markets,” NBER Working Paper 18175 (Cambridge, MA: NBER). 
Figure 1. Capital Flows to EMEs, 2005Q1-2013Q4

(In USD billion)

a) Net, liability and asset flows

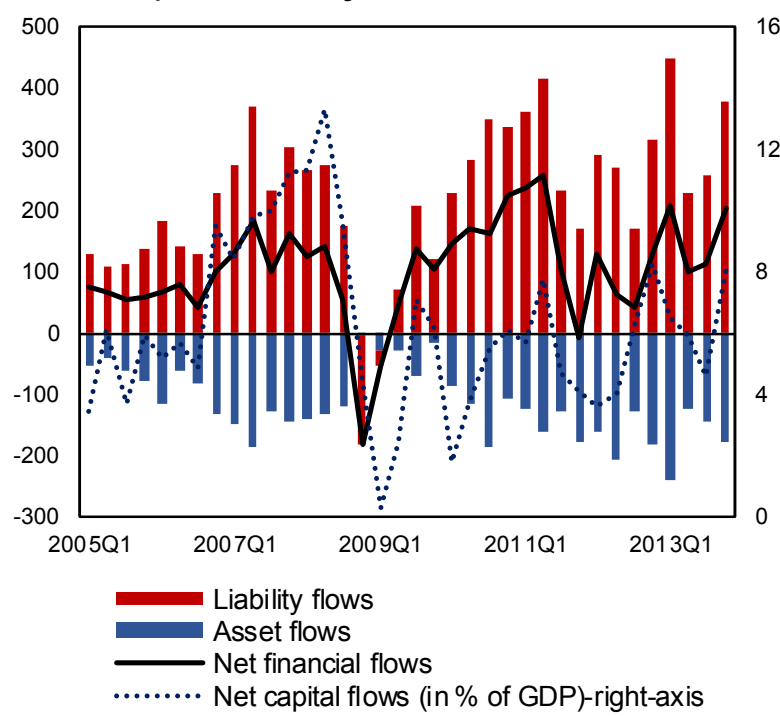

b) Net flows by type

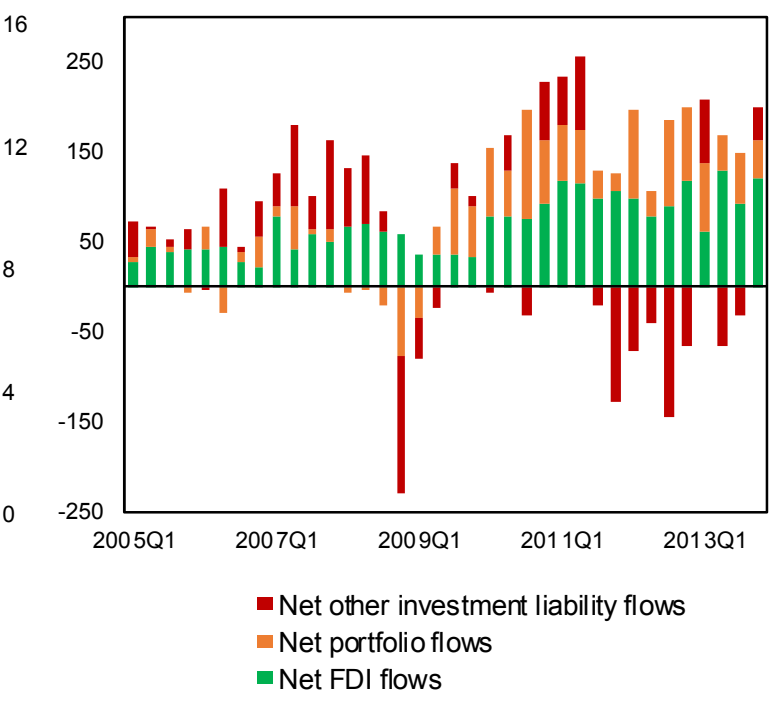

Source: Authors' calculations based on IMF's IFS database.

Notes: Net financial flows exclude other investment liabilities of the general government and reserve assets. Flows are the sum for all EMEs in the sample.

Figure 2. Capital Flows and Macroeconomic Policy Response in EMEs, 2005Q1-2013Q4

a) FX reserve flows and policy rate

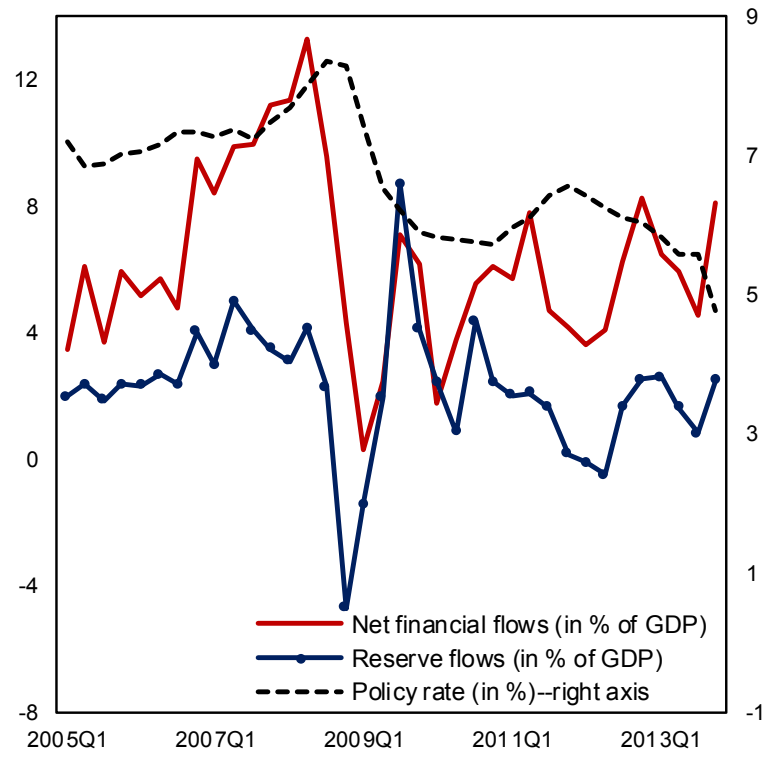

b) Real government expenditure

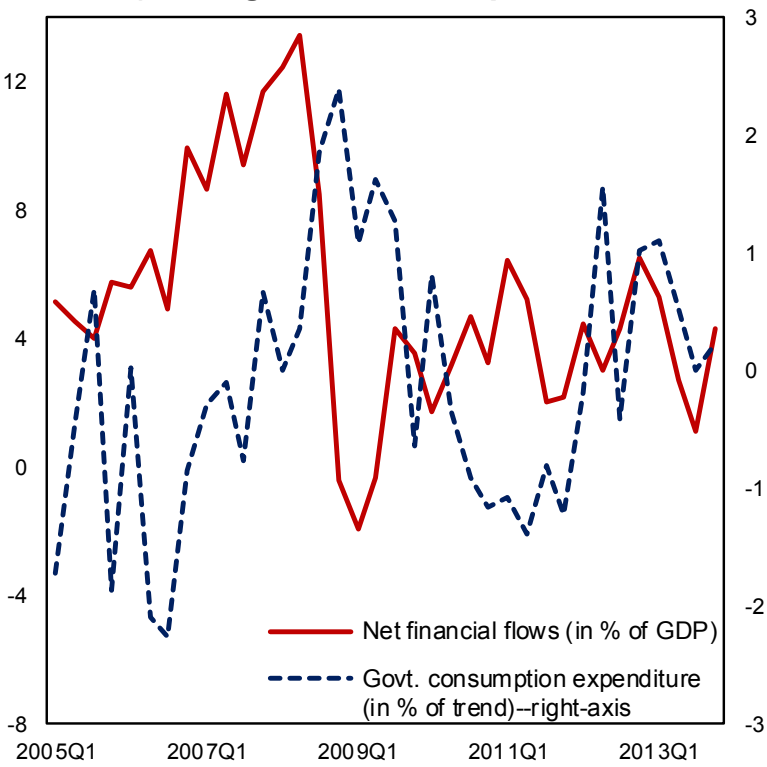

Source: Authors' calculations based on IMF's IFS and WEO databases.

Notes: Statistics are averages for the corresponding samples. Real government expenditure is the cyclical component of real government spending (seasonally adjusted) in percent of trend real government spending. 
Figure 3. Capital Flows and Macroprudential Measures in EMEs, 2005Q1-2013Q4

a) Domestic macroprudential measures

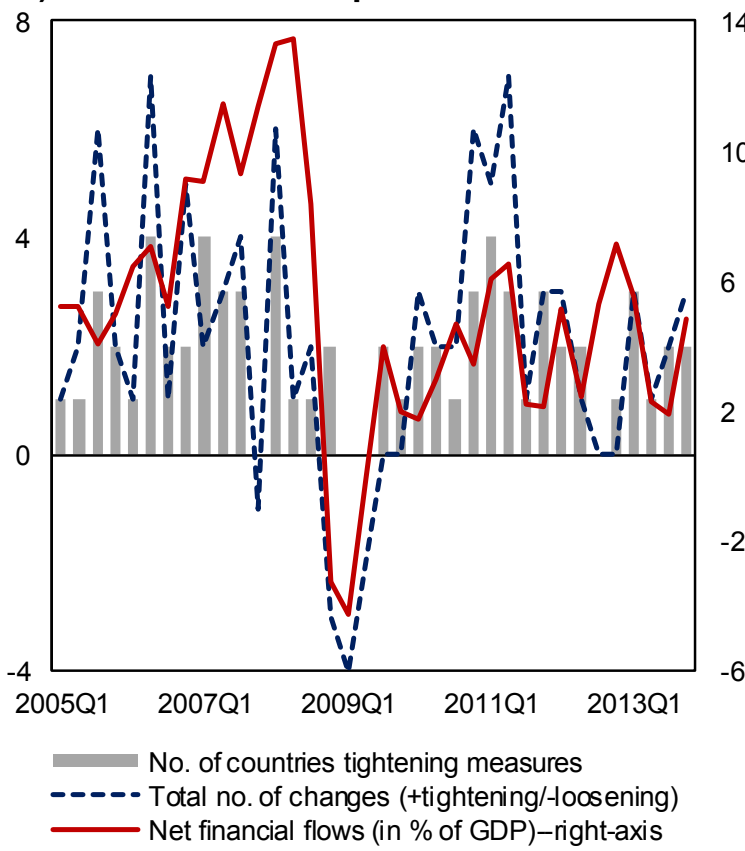

b) Reserve requirement on deposits

\section{4}

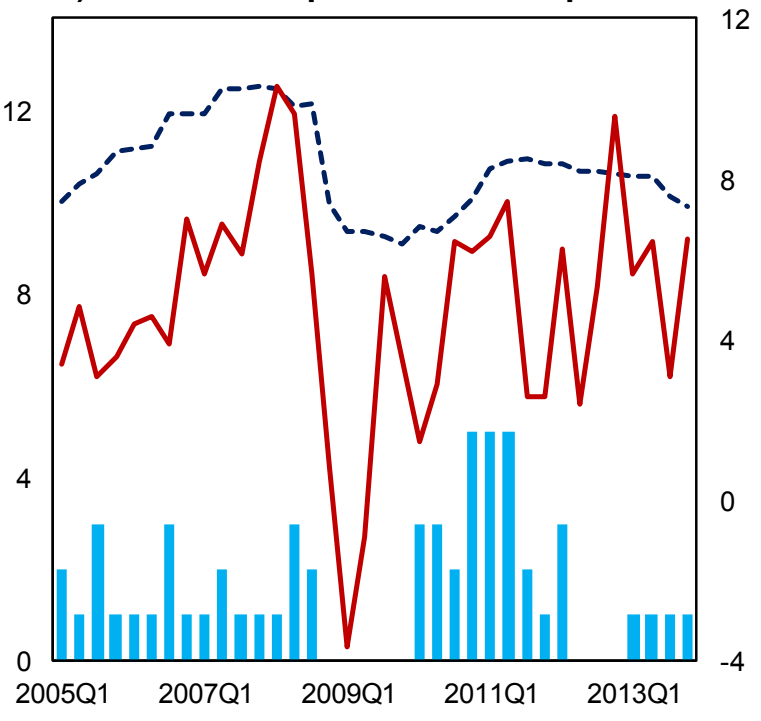

No. of countries tightening RR

- - Average RR (in \%)

Net financial flows (in \% of GDP)-right-axis

Sources: IMF's IFS database, Federico et al. (2014), and Akinci- Olmstead-Rumsey (2015).

Notes: Net financial flows are the average for countries for which information on respective macroprudential policies/RR is available.

Figure 4. Capital Flows and Inflow Controls in EMEs, 2005Q1-2013Q4

a) Inflow controls

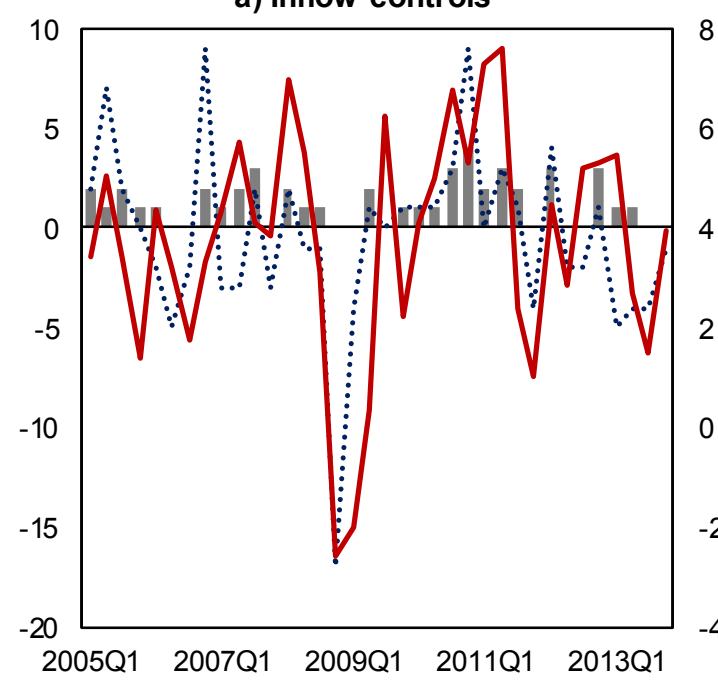

No. of countries tightening inflow controls
$\ldots . . .$. Total no. of changes (+tightening/-loosening)
Net financial flows (in \% of GDP)-right-axis b) Outflow controls

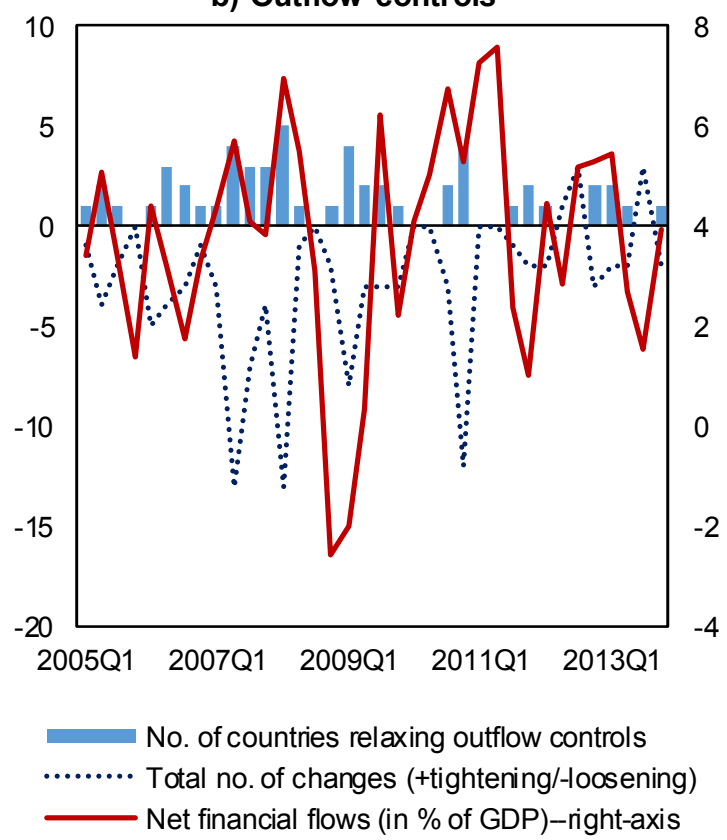

Sources: IMF's IFS database, Ahmed et al. (2015), and authors' calculations based on IMF's AREAER.

Notes: Net financial flows is the average for the 17 countries in the sample for which information on changes in capital controls is available. Total no. of changes in panels [a] and [b] are the cumulative number of measures tightened net of measures relaxed for the countries in the sample. 
Figure 5. Policy Instruments and Risks, 2005Q1-2013Q4

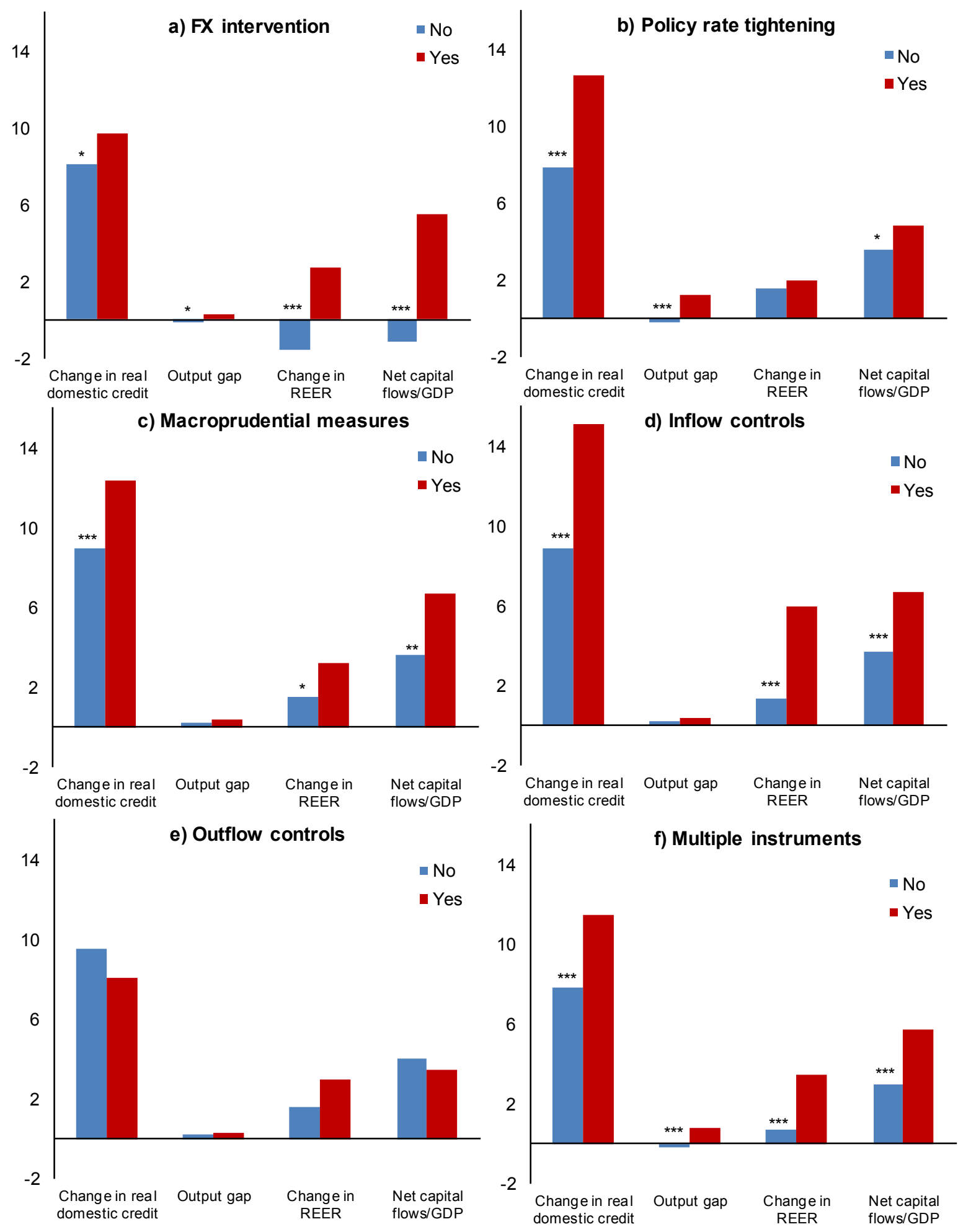

Source: Authors' estimates.

Note: Figures shows the average year-on-year change in real domestic private credit growth and change in REER (in percent), output gap (in percent), and net capital flow/GDP (in percent) for the cases when policy instruments are used, and when they are not used. Sample comprises those observations for which information on all policy instruments is available. ${ }^{*},{ }^{* *}$, and ${ }^{* * *}$ indicate that the difference between the two group means is statistically significant at the 10,5 , and 1 percent levels, respectively. 
Figure 6. Policy Responses in Inflow Surges in EMEs

(a) Individual policy response

(In percent of surge/normal flow observations)

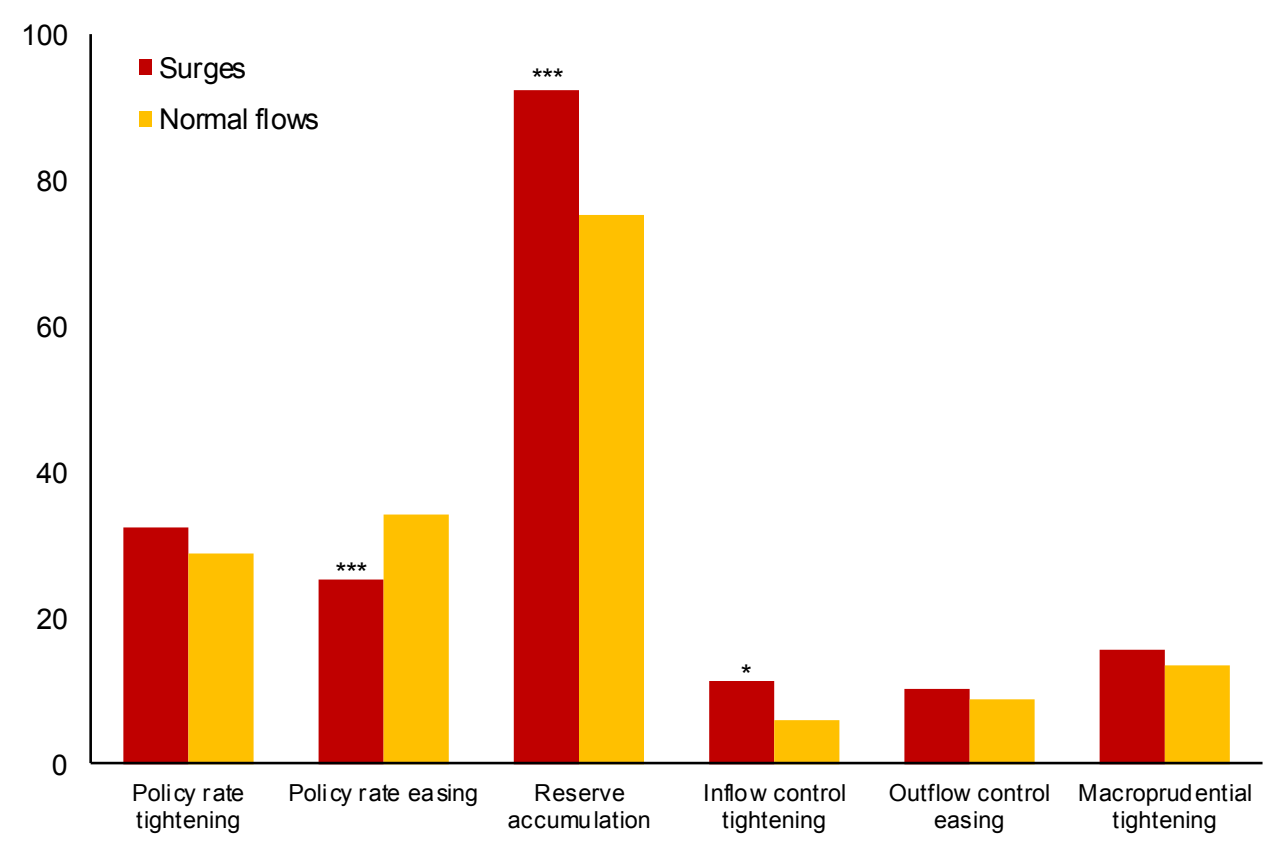

(b) Policy combinations

(In percent of surge/normal flow observations)

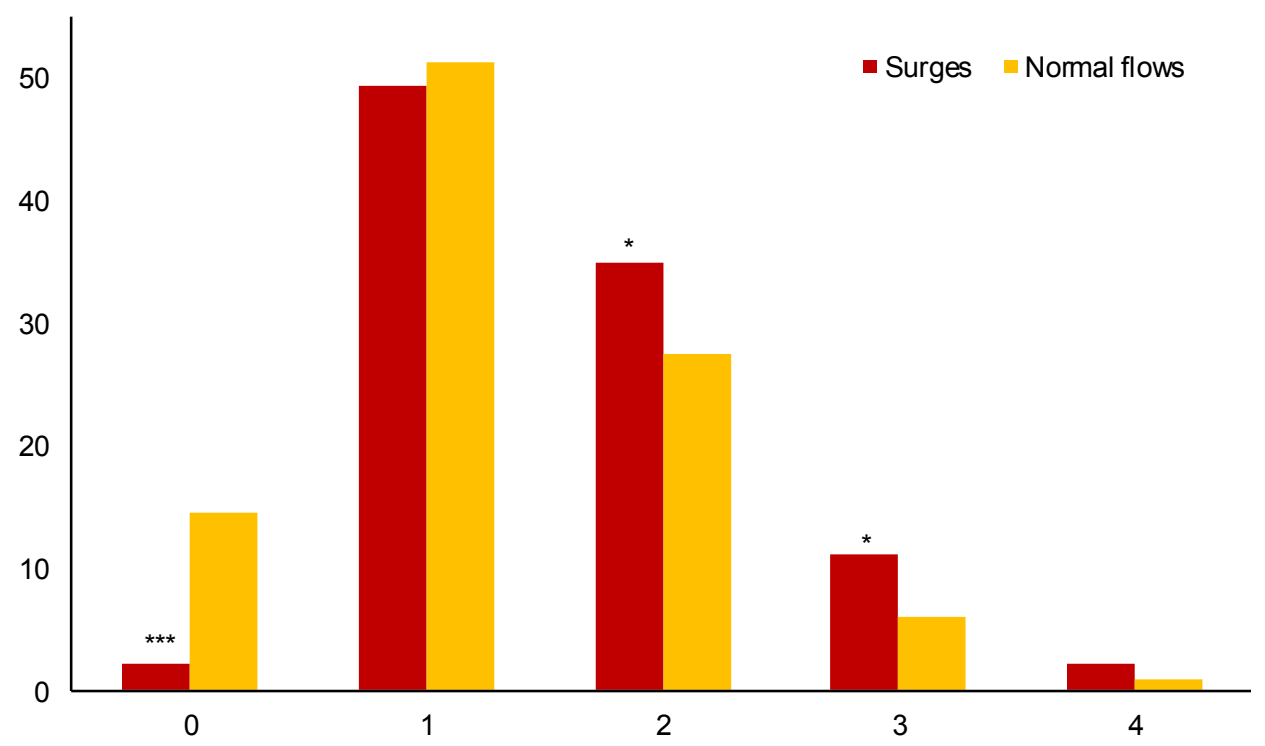

Source: Authors' estimates.

Note: Figures show the percentage of large inflow/normal flow observations in which the respective policy instruments are deployed. Sample comprises those observations for which information on all policy instruments is available. ${ }^{*},{ }^{* *}$, and ${ }^{* * *}$ indicate that the difference between the two group means is statistically significant at the 10,5 , and 1 percent levels, respectively. 
Table 1. Net Capital Flows and Macroeconomic Policy Response in EMEs, 2005Q1-2013Q4

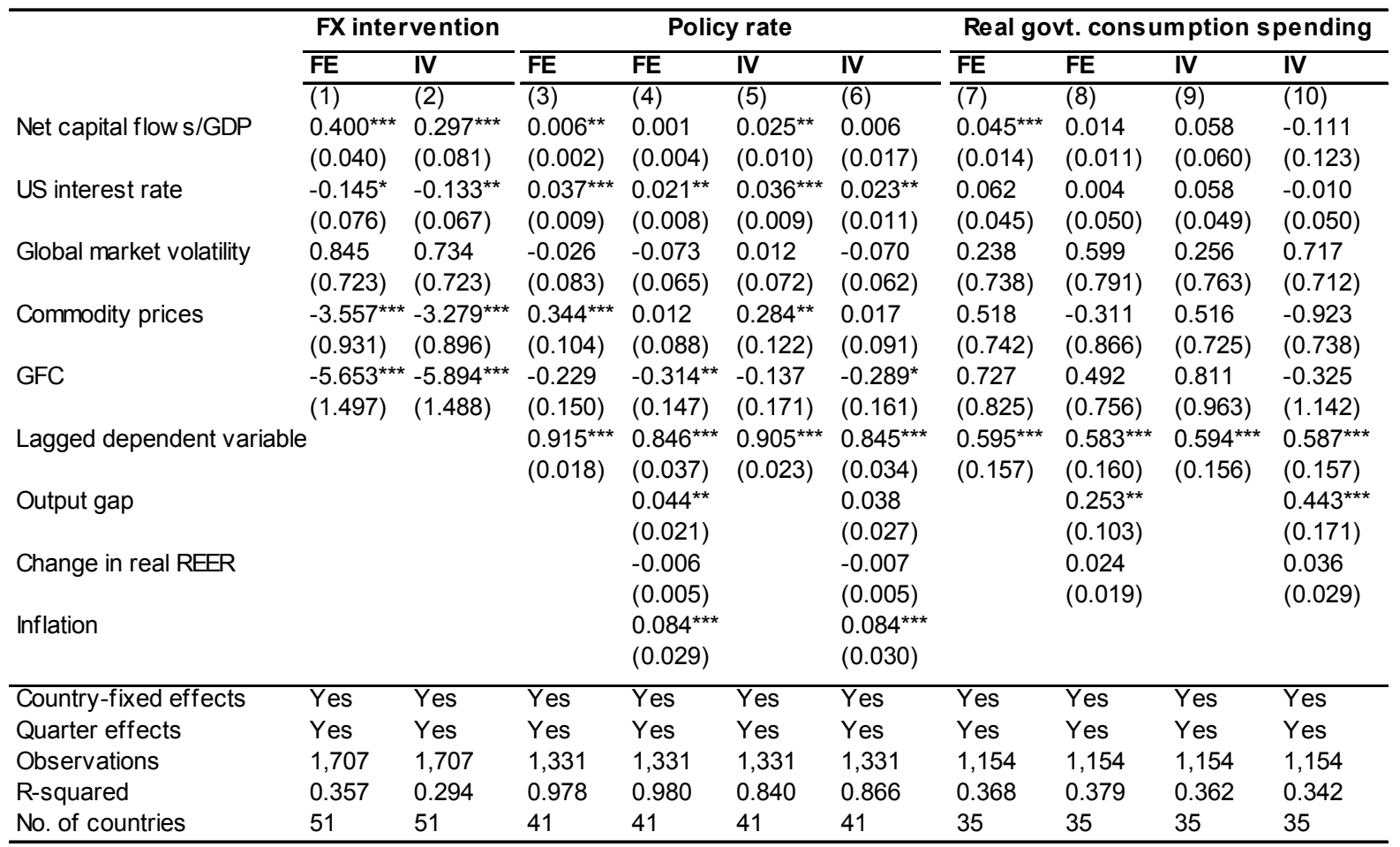

Note: Dependent variable is change in reserves (excluding valuation changes) in percent of GDP in cols. [1]-[2], central bank policy rate in cols. [3]-[6], cyclical component of real government consumption spending (in percent of trend) in cols. [7]-[10]. FE is estimation with OLS method including countryfixed effects. IV is instrumental variable-two stage least squares approach with net financial flows to the region (in percent of regional GDP) used as instrument for net capital flows (in percent of GDP). Global market volatility is log of VIX index. Commodity prices are in logs. US interest rate is inflation-adjusted 3-month T-bill rate. GFC is a binary variable (=1) for the glo bal financial crisis (2008Q4-2009Q1). See Appendix for the description of other variables and data sources. All regressions include a constant, country-fixed, and quarter effects. Clustered standard errors are reported in parentheses. ${ }^{* \star *},{ }^{* *}$ and ${ }^{*}$ indicate statistical significance at the 1,5 and 10 percent levels, respectively.

Table 2. Net Inflows and Outflows and Policy Response in EMEs, 2005Q1-2013Q4

\begin{tabular}{|c|c|c|c|c|c|c|}
\hline & \multicolumn{2}{|c|}{ FX intervention } & \multicolumn{2}{|c|}{ Policy rate } & \multicolumn{2}{|c|}{ Govt. consumption spending } \\
\hline & Net flow s >0 & Net flow s $<0$ & Net flow s $>0$ & Net flow s $<0$ & Net flow s $>0$ & Net flow $s<0$ \\
\hline & $\overline{(1)}$ & (2) & (3) & (4) & (5) & $(6)$ \\
\hline Net capital flow s/GDP & $\begin{array}{l}0.412^{* * *} \\
(0.046)\end{array}$ & $\begin{array}{l}0.652^{* * *} \\
(0.064)\end{array}$ & $\begin{array}{l}0.006^{* *} \\
(0.003)\end{array}$ & $\begin{array}{l}-0.005 \\
(0.008)\end{array}$ & $\begin{array}{l}0.050^{*} \\
(0.029)\end{array}$ & $\begin{array}{l}-0.019 \\
(0.043)\end{array}$ \\
\hline US interest rate & $\begin{array}{l}0.648 \\
(0.962)\end{array}$ & $\begin{array}{l}2.011^{* *} \\
(0.874)\end{array}$ & $\begin{array}{l}-0.042 \\
(0.104)\end{array}$ & $\begin{array}{l}-0.079 \\
(0.133)\end{array}$ & $\begin{array}{l}0.073 \\
(0.058)\end{array}$ & $\begin{array}{l}-0.008 \\
(0.105)\end{array}$ \\
\hline Global market volatility & $\begin{array}{l}-3.360^{* * *} \\
(1.173)\end{array}$ & $\begin{array}{l}-2.823 \\
(2.282)\end{array}$ & $\begin{array}{l}0.394^{* *} \\
(0.151)\end{array}$ & $\begin{array}{l}0.257 \\
(0.163)\end{array}$ & $\begin{array}{l}0.880 \\
(0.808)\end{array}$ & $\begin{array}{l}-0.460 \\
(0.714)\end{array}$ \\
\hline Commodity prices & $\begin{array}{l}-0.122 \\
(0.076)\end{array}$ & $\begin{array}{l}-0.085 \\
(0.168)\end{array}$ & $\begin{array}{l}0.037^{\star \star *} \\
(0.012)\end{array}$ & $\begin{array}{l}0.027^{* *} \\
(0.012)\end{array}$ & $\begin{array}{l}0.475 \\
(0.764)\end{array}$ & $\begin{array}{l}-1.033 \\
(1.230)\end{array}$ \\
\hline GFC & $\begin{array}{l}-5.234^{\star * *} \\
(1.934)\end{array}$ & $\begin{array}{l}-6.076^{\star * *} \\
(2.200)\end{array}$ & $\begin{array}{l}-0.151 \\
(0.212)\end{array}$ & $\begin{array}{l}-0.234 \\
(0.297)\end{array}$ & $\begin{array}{l}1.413 \\
(1.269)\end{array}$ & $\begin{array}{l}1.073 \\
(1.791)\end{array}$ \\
\hline Lagged dependent variable & & & $\begin{array}{l}0.938^{\star \star *} \\
(0.034)\end{array}$ & $\begin{array}{l}0.867^{* * *} \\
(0.024)\end{array}$ & $\begin{array}{l}0.519^{* * *} \\
(0.144)\end{array}$ & $\begin{array}{l}0.572^{\star * *} \\
(0.145)\end{array}$ \\
\hline Country-fixed effects & Yes & Yes & Yes & Yes & Yes & Yes \\
\hline Quarter effects & Yes & Yes & Yes & Yes & Yes & Yes \\
\hline Observations & 1,312 & 395 & 1,002 & 329 & 850 & 304 \\
\hline $\mathrm{R} 2$ & 0.322 & 0.516 & 0.969 & 0.993 & 0.302 & 0.668 \\
\hline No. of countries & 51 & 50 & 41 & 40 & 35 & 33 \\
\hline
\end{tabular}


Table 3. Macroeconomic Policy Response and the Composition of Flows, 2005Q1-2013Q4

\begin{tabular}{|c|c|c|c|c|c|c|c|c|c|c|}
\hline & \multicolumn{2}{|c|}{ FX Intervention } & \multicolumn{4}{|c|}{ Policy Rate } & \multicolumn{4}{|c|}{ Govt. cons umption spending } \\
\hline & (1) & $(2)$ & (3) & $(4)$ & $(5)$ & $(6)$ & (7) & $(8)$ & (9) & $(10)$ \\
\hline Asset flow s/GDP & $\begin{array}{c}0.428^{* * *} \\
(0.040)\end{array}$ & & $\begin{array}{c}0.002 \\
(0.003)\end{array}$ & & $\begin{array}{c}-0.001 \\
(0.003)\end{array}$ & & $\begin{array}{l}0.040^{* *} \\
(0.018)\end{array}$ & $\begin{array}{l}0.020 \\
(0.017)\end{array}$ & & \\
\hline Liability flow s/GDP & $\begin{array}{c}0.392^{* * *} \\
(0.041)\end{array}$ & & $\begin{array}{l}0.007^{* * *} \\
(0.002)\end{array}$ & & $\begin{array}{c}0.002 \\
(0.004)\end{array}$ & & $\begin{array}{l}0.045^{* * *} \\
(0.014)\end{array}$ & $\begin{array}{l}0.013 \\
(0.010)\end{array}$ & & \\
\hline Net FDI flow s/GDP & & $\begin{array}{c}0.313^{* * *} \\
(0.068)\end{array}$ & & $\begin{array}{l}0.026^{* *} \\
(0.011)\end{array}$ & & $\begin{array}{c}0.013 \\
(0.008)\end{array}$ & & & $\begin{array}{l}0.034 \\
(0.045)\end{array}$ & $\begin{array}{l}-0.005 \\
(0.037)\end{array}$ \\
\hline Net portfolio flow s/GDP & & $\begin{array}{c}0.535^{\star * *} \\
(0.046)\end{array}$ & & $\begin{array}{c}-0.000 \\
(0.003)\end{array}$ & & $\begin{array}{c}-0.000 \\
(0.004)\end{array}$ & & & $\begin{array}{l}0.050^{* *} \\
(0.022)\end{array}$ & $\begin{array}{l}0.032 \\
(0.020)\end{array}$ \\
\hline Net other inv. flow s/GDP & & $\begin{array}{c}0.390^{* * *} \\
(0.046)\end{array}$ & & $\begin{array}{c}0.004 \\
(0.002)\end{array}$ & & $\begin{array}{c}-0.000 \\
(0.004)\end{array}$ & & & $\begin{array}{l}0.046^{* * *} \\
(0.016)\end{array}$ & $\begin{array}{l}0.014 \\
(0.016)\end{array}$ \\
\hline US interest rate & $\begin{array}{l}-0.139^{*} \\
(0.075)\end{array}$ & $\begin{array}{c}-0.115 \\
(0.070)\end{array}$ & $\begin{array}{c}0.036^{* * *} \\
(0.009)\end{array}$ & $\begin{array}{c}0.035^{* * *} \\
(0.009)\end{array}$ & $\begin{array}{l}0.021^{* *} \\
(0.008)\end{array}$ & $\begin{array}{l}0.021^{* *} \\
(0.008)\end{array}$ & $\begin{array}{l}0.060 \\
(0.046)\end{array}$ & $\begin{array}{l}0.005 \\
(0.050)\end{array}$ & $\begin{array}{l}0.063 \\
(0.046)\end{array}$ & $\begin{array}{l}0.007 \\
(0.050)\end{array}$ \\
\hline Global market volatility & $\begin{array}{c}0.810 \\
(0.732)\end{array}$ & $\begin{array}{c}1.061 \\
(0.734)\end{array}$ & $\begin{array}{l}-0.020 \\
(0.082)\end{array}$ & $\begin{array}{l}-0.033 \\
(0.080)\end{array}$ & $\begin{array}{c}-0.072 \\
(0.064)\end{array}$ & $\begin{array}{l}-0.073 \\
(0.063)\end{array}$ & $\begin{array}{l}0.244 \\
(0.748)\end{array}$ & $\begin{array}{l}0.599 \\
(0.789)\end{array}$ & $\begin{array}{l}0.237 \\
(0.737)\end{array}$ & $\begin{array}{l}0.631 \\
(0.792)\end{array}$ \\
\hline Commodity prices & $\begin{array}{c}-3.481^{* * *} \\
(0.935)\end{array}$ & $\begin{array}{c}-3.833^{* * *} \\
(1.000)\end{array}$ & $\begin{array}{c}0.334^{* * *} \\
(0.104)\end{array}$ & $\begin{array}{c}0.327^{* * *} \\
(0.098)\end{array}$ & $\begin{array}{c}0.014 \\
(0.088)\end{array}$ & $\begin{array}{c}0.012 \\
(0.086)\end{array}$ & $\begin{array}{l}0.508 \\
(0.756)\end{array}$ & $\begin{array}{l}-0.318 \\
(0.855)\end{array}$ & $\begin{array}{l}0.516 \\
(0.742)\end{array}$ & $\begin{array}{l}-0.380 \\
(0.874)\end{array}$ \\
\hline GFC & $\begin{array}{c}-5.806^{* * *} \\
(1.520)\end{array}$ & $\begin{array}{c}-5.720^{* * *} \\
(1.527)\end{array}$ & $\begin{array}{l}-0.213 \\
(0.146)\end{array}$ & $\begin{array}{c}-0.246 \\
(0.149)\end{array}$ & $\begin{array}{c}-0.305^{\star *} \\
(0.145)\end{array}$ & $\begin{array}{c}-0.318^{* *} \\
(0.146)\end{array}$ & $\begin{array}{l}0.746 \\
(0.838)\end{array}$ & $\begin{array}{l}0.463 \\
(0.763)\end{array}$ & $\begin{array}{l}0.725 \\
(0.825)\end{array}$ & $\begin{array}{l}0.489 \\
(0.759)\end{array}$ \\
\hline Output gap & & & & & $\begin{array}{c}0.042^{*} \\
(0.022)\end{array}$ & $\begin{array}{c}0.041^{*} \\
(0.022)\end{array}$ & & $\begin{array}{l}0.259^{* *} \\
(0.100)\end{array}$ & & $\begin{array}{l}0.262^{* *} \\
(0.104)\end{array}$ \\
\hline Change in REER & & & & & $\begin{array}{c}-0.006 \\
(0.005)\end{array}$ & $\begin{array}{c}-0.006 \\
(0.005)\end{array}$ & & $\begin{array}{l}0.024 \\
(0.020)\end{array}$ & & $\begin{array}{l}0.024 \\
(0.019)\end{array}$ \\
\hline Inflation & & & & & $\begin{array}{c}0.084^{* * *} \\
(0.029)\end{array}$ & $\begin{array}{c}0.082^{* * *} \\
(0.028)\end{array}$ & & & & \\
\hline $\begin{array}{l}\text { Lagged dependent } \\
\text { variable }\end{array}$ & & & $\begin{array}{l}0.914^{* * *} \\
(0.018)\end{array}$ & $\begin{array}{l}0.909 * * * \\
(0.017)\end{array}$ & $\begin{array}{l}0.846^{* * *} \\
(0.037)\end{array}$ & $\begin{array}{l}0.845^{* * *} \\
(0.037)\end{array}$ & $\begin{array}{l}0.595^{\star * *} \\
(0.158)\end{array}$ & $\begin{array}{l}{ }^{*} 0.583^{* * *} \\
(0.159)\end{array}$ & $\begin{array}{l}0.595^{\star * *} \\
(0.157)\end{array}$ & $\begin{array}{l}0.583^{* * *} \\
(0.160)\end{array}$ \\
\hline Country-fixed effects & Yes & Yes & Yes & Yes & Yes & Yes & Yes & Yes & Yes & Yes \\
\hline Quarter effects & Yes & Yes & Yes & Yes & Yes & Yes & Yes & Yes & Yes & Yes \\
\hline Observations & 1,707 & 1,707 & 1,331 & 1,331 & 1,331 & 1,331 & 1,154 & 1,154 & 1,154 & 1,154 \\
\hline R-squared & 0.359 & 0.372 & 0.978 & 0.978 & 0.980 & 0.980 & 0.368 & 0.379 & 0.368 & 0.379 \\
\hline No. of countries & 51 & 51 & 41 & 41 & 41 & 41 & 35 & 35 & 35 & 35 \\
\hline
\end{tabular}


Table 4. Net Capital Flows and Macroprudential Policy Response in EMEs, 2005Q1-2013Q4

\begin{tabular}{|c|c|c|c|c|c|c|c|c|c|c|}
\hline & \multicolumn{2}{|c|}{ Overall } & \multirow{2}{*}{$\begin{array}{l}\text { CCR } \\
\text { FE }\end{array}$} & \multirow{2}{*}{$\begin{array}{l}\text { LLP } \\
\text { FE }\end{array}$} & \multirow{2}{*}{$\begin{array}{c}\begin{array}{c}\text { Cons umer } \\
\text { loan lim it }\end{array} \\
\text { FE }\end{array}$} & \multirow{2}{*}{$\begin{array}{c}\text { Credit } \\
\text { growth lim it } \\
\text { FE }\end{array}$} & \multirow{2}{*}{$\begin{array}{l}\text { DTI } \\
\text { FE }\end{array}$} & \multirow{2}{*}{$\begin{array}{c}\text { LTV } \\
\text { FE }\end{array}$} & \multicolumn{2}{|c|}{ RR } \\
\hline & FE & $\mathrm{N}$ & & & & & & & FE & $\bar{N}$ \\
\hline & (1) & (2) & (3) & $(4)$ & (5) & (6) & (7) & (8) & (9) & (10) \\
\hline \multirow[t]{2}{*}{ Net capital flow s/GDP } & $0.018^{*}$ & $0.031^{* *}$ & 0.010 & 0.013 & 0.051 & 0.019 & $0.080^{\star \star}$ & $0.030^{\star *}$ & $0.013^{* *}$ & $0.042^{*}$ \\
\hline & $(0.009)$ & $(0.014)$ & $(0.011)$ & $(0.010)$ & $(0.032)$ & $(0.015)$ & $(0.031)$ & $(0.012)$ & $(0.005)$ & $(0.025)$ \\
\hline \multirow[t]{2}{*}{ US interest rate } & 0.009 & 0.004 & -0.003 & 0.050 & 0.069 & -0.085 & $-0.077^{* *}$ & -0.045 & 0.015 & 0.017 \\
\hline & $(0.025)$ & $(0.022)$ & $(0.022)$ & $(0.038)$ & $(0.106)$ & $(0.083)$ & $(0.037)$ & $(0.051)$ & $(0.022)$ & $(0.022)$ \\
\hline \multirow[t]{2}{*}{ Global market volatility } & -0.203 & -0.186 & $0.597^{*}$ & $-0.647^{* *}$ & 0.262 & -1.759 & -0.716 & $-0.767^{\star \star \star}$ & -0.290 & -0.270 \\
\hline & $(0.277)$ & $(0.237)$ & $(0.358)$ & $(0.287)$ & $(0.682)$ & (1.495) & $(0.846)$ & $(0.279)$ & $(0.227)$ & $(0.210)$ \\
\hline \multirow[t]{2}{*}{ GFC } & 0.093 & 0.113 & 0.019 & 0.749 & $-5.682^{* \star *}$ & -0.738 & $-4.118^{* * *}$ & $-3.483^{\star \star \star}$ & $-0.918^{*}$ & $-0.842^{*}$ \\
\hline & $(0.493)$ & $(0.458)$ & $(0.757)$ & $(0.538)$ & $(1.166)$ & $(1.982)$ & $(0.835)$ & $(0.445)$ & $(0.520)$ & $(0.447)$ \\
\hline \multirow[t]{2}{*}{ Real GDP grow th } & 0.022 & -0.002 & 0.109 & 0.023 & $-0.112^{\star \star *}$ & $0.213^{*}$ & $-0.189^{* *}$ & -0.054 & 0.021 & -0.009 \\
\hline & $(0.054)$ & $(0.044)$ & $(0.090)$ & $(0.073)$ & $(0.018)$ & $(0.119)$ & $(0.081)$ & $(0.079)$ & $(0.027)$ & $(0.025)$ \\
\hline \multirow[t]{2}{*}{ Initial RR } & & & & & & & & & $0.917^{\star \star *}$ & $0.910^{* \star *}$ \\
\hline & & & & & & & & & $(0.014)$ & $(0.010)$ \\
\hline Country fixed effects & Yes & Yes & Yes & Yes & Yes & Yes & Yes & Yes & Yes & Yes \\
\hline Quarter effects & Yes & Yes & Yes & Yes & Yes & Yes & Yes & Yes & Yes & Yes \\
\hline Observations & 924 & 924 & 924 & 924 & 924 & 924 & 924 & 924 & 968 & 968 \\
\hline No. of countries & 27 & 27 & 27 & 27 & 27 & 27 & 27 & 27 & 32 & 32 \\
\hline $\mathrm{R}^{2}$ & 0.163 & & 0.250 & 0.209 & 0.408 & 0.475 & 0.472 & 0.332 & 0.960 & 0.840 \\
\hline \multicolumn{11}{|c|}{ 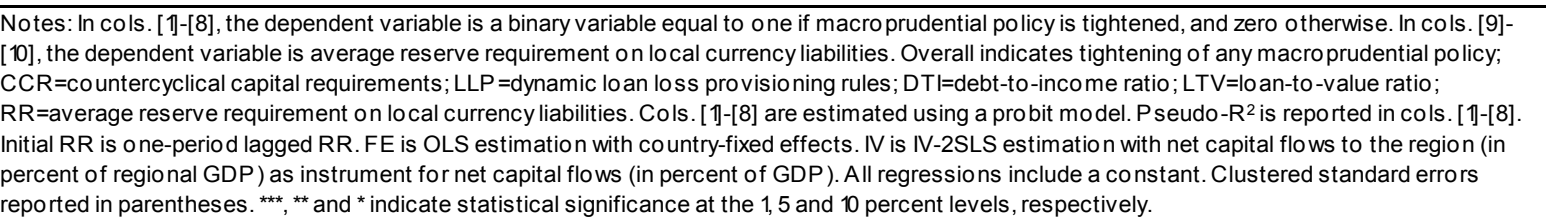 } \\
\hline
\end{tabular}

Table 5. Macroprudential Policies and Composition of Flows, 2005Q1-2013Q4

\begin{tabular}{|c|c|c|c|c|c|c|c|c|}
\hline & \multicolumn{2}{|c|}{ Overall } & \multicolumn{2}{|c|}{ DTI } & \multicolumn{2}{|c|}{ LTV } & \multicolumn{2}{|c|}{ RR } \\
\hline & (1) & $(2)$ & (3) & (4) & (5) & (6) & (7) & $(8)$ \\
\hline Asset flow s/GDP & $\begin{array}{c}0.014 \\
(0.011)\end{array}$ & & $\begin{array}{l}0.082^{* *} \\
(0.035)\end{array}$ & & $\begin{array}{l}0.026^{* *} \\
(0.013)\end{array}$ & & $\begin{array}{l}0.026^{*} \\
(0.013)\end{array}$ & \\
\hline Liability flow s/GDP & $\begin{array}{l}0.019^{\star *} \\
(0.009)\end{array}$ & & $\begin{array}{l}0.080^{* *} \\
(0.032)\end{array}$ & & $\begin{array}{l}0.029^{* *} \\
(0.012)\end{array}$ & & $\begin{array}{l}0.011^{*} \\
(0.006)\end{array}$ & \\
\hline Net FDI flow s/GDP & & $\begin{array}{c}-0.005 \\
(0.018)\end{array}$ & & $\begin{array}{l}0.069 \\
(0.056)\end{array}$ & & $\begin{array}{l}-0.010 \\
(0.014)\end{array}$ & & $\begin{array}{l}-0.007 \\
(0.026)\end{array}$ \\
\hline Net portfolio flow s/GDP & & $\begin{array}{l}0.047^{* * *} \\
(0.013)\end{array}$ & & $\begin{array}{l}0.075^{\star *} \\
(0.032)\end{array}$ & & $\begin{array}{l}0.069^{* \star *} \\
(0.014)\end{array}$ & & $\begin{array}{l}0.012 \\
(0.010)\end{array}$ \\
\hline Net other inv. flow s/GDP & & $\begin{array}{l}0.024^{* *} \\
(0.011)\end{array}$ & & $\begin{array}{l}0.092^{* * *} \\
(0.033)\end{array}$ & & $\begin{array}{l}0.052^{* * *} \\
(0.014)\end{array}$ & & $\begin{array}{l}0.018^{* * *} \\
(0.005)\end{array}$ \\
\hline US interest rate & $\begin{array}{c}0.008 \\
(0.024)\end{array}$ & $\begin{array}{c}0.016 \\
(0.025)\end{array}$ & $\begin{array}{c}-0.075^{* *} \\
(0.038)\end{array}$ & $\begin{array}{c}-0.092^{* *} \\
(0.043)\end{array}$ & $\begin{array}{l}-0.046 \\
(0.052)\end{array}$ & $\begin{array}{c}-0.049 \\
(0.050)\end{array}$ & $\begin{array}{l}0.019 \\
(0.022)\end{array}$ & $\begin{array}{l}0.014 \\
(0.022)\end{array}$ \\
\hline Global market volatility & $\begin{array}{l}-0.198 \\
(0.276)\end{array}$ & $\begin{array}{c}-0.197 \\
(0.289)\end{array}$ & $\begin{array}{l}-0.726 \\
(0.852)\end{array}$ & $\begin{array}{l}-0.776 \\
(0.800)\end{array}$ & $\begin{array}{c}-0.760^{\star \star * *} \\
(0.270)\end{array}$ & $\begin{array}{c}-0.907^{\star * *} \\
(0.300)\end{array}$ & $\begin{array}{l}-0.289 \\
(0.225)\end{array}$ & $\begin{array}{l}-0.290 \\
(0.222)\end{array}$ \\
\hline GFC & $\begin{array}{c}0.102 \\
(0.488)\end{array}$ & $\begin{array}{c}0.215 \\
(0.501)\end{array}$ & $\begin{array}{c}-4.131^{\text {}}(0.852)\end{array}$ & $\begin{array}{c}-4.660^{* * *} \\
(1.116)\end{array}$ & $\begin{array}{c}-3.462^{* * *} \\
(0.467)\end{array}$ & $\begin{array}{c}-3.532^{* * *} \\
(0.450)\end{array}$ & $\begin{array}{l}-0.976^{*} \\
(0.567)\end{array}$ & $\begin{array}{l}-0.923^{*} \\
(0.500)\end{array}$ \\
\hline Real GDP grow th & $\begin{array}{c}0.022 \\
(0.054)\end{array}$ & $\begin{array}{c}0.027 \\
(0.056)\end{array}$ & $\begin{array}{c}-0.191^{* *} \\
(0.083)\end{array}$ & $\begin{array}{c}-0.224^{* * *} \\
(0.082)\end{array}$ & $\begin{array}{c}-0.052 \\
(0.079)\end{array}$ & $\begin{array}{c}-0.050 \\
(0.080)\end{array}$ & $\begin{array}{l}0.026 \\
(0.031)\end{array}$ & $\begin{array}{l}0.021 \\
(0.029)\end{array}$ \\
\hline Initial RR & & & & & & & $\begin{array}{l}0.920^{* * *} \\
(0.016)\end{array}$ & $\begin{array}{l}0.919^{* * *} \\
(0.017)\end{array}$ \\
\hline Country fixed effects & Yes & Yes & Yes & Yes & Yes & Yes & Yes & Yes \\
\hline Quarter effects & Yes & Yes & Yes & Yes & Yes & Yes & Yes & Yes \\
\hline Observations & 924 & 924 & 924 & 924 & 924 & 924 & 968 & 968 \\
\hline $\mathrm{R}^{2}$ & 0.164 & 0.172 & 0.472 & 0.478 & 0.332 & 0.351 & 0.961 & 0.960 \\
\hline
\end{tabular}

Notes: In cols. [1]-[6], the dependent variable is a binary variable equal to one if macro prudential policy is tightened, and zero otherwise. In cols. [7]-[8], the dependent variable is average RR on local currency liabilities. See Table 8.6 for variable descriptions Cols. [1]-[6] are estimated using a probit model and pseudo-R2 is reported. All regressions include a constant. Clustered standard errors are reported in parentheses. ${ }^{* * *},{ }^{* *}$ and * indicate statistical significance at the 1,5 and 10 percent levels, respectively. 
Table 6. Net Capital Flows and Capital Controls in EMEs, 2005Q1-2013Q4

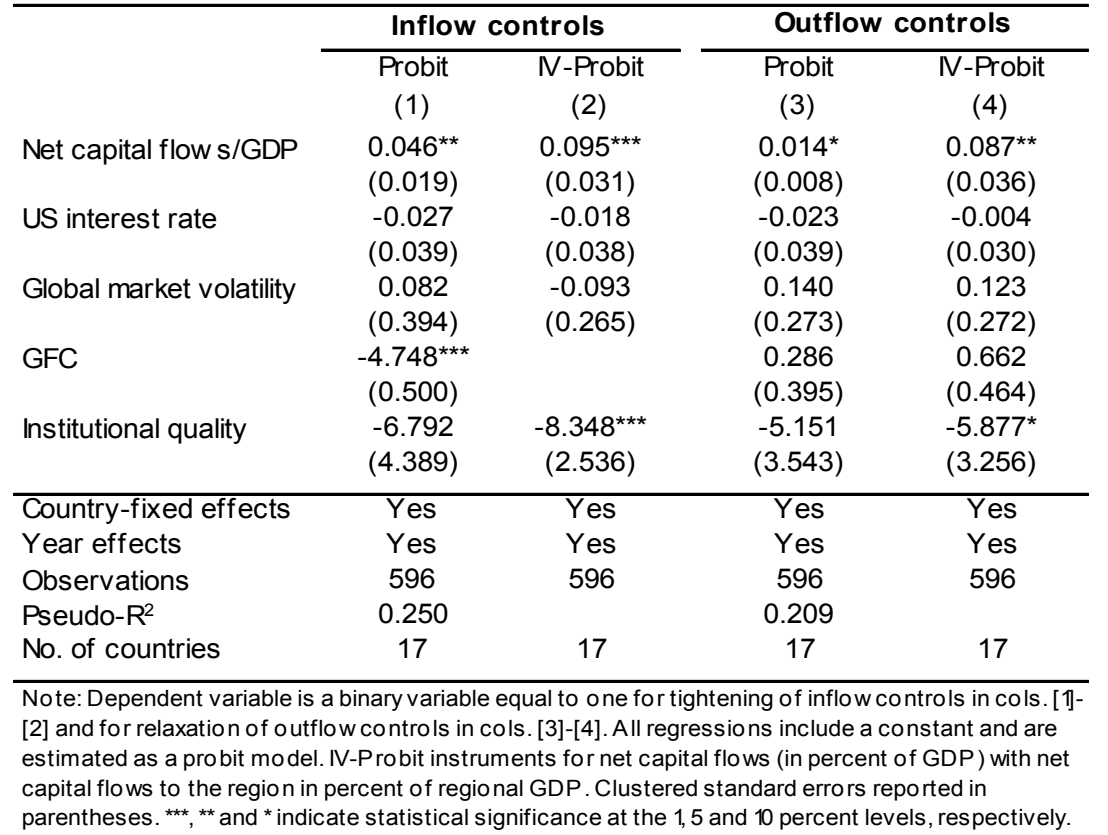

Table 7. Capital Controls and Composition of Flows, 2005Q1-2013Q4

\begin{tabular}{|c|c|c|c|c|c|c|c|c|c|c|}
\hline & \multicolumn{5}{|c|}{ Inflow controls } & \multicolumn{5}{|c|}{ Outflow controls } \\
\hline & \multicolumn{2}{|c|}{ Overall } & \multirow{2}{*}{$\begin{array}{c}\text { Equity } \\
(3)\end{array}$} & \multirow{2}{*}{$\begin{array}{c}\text { Bond } \\
(4)\end{array}$} & \multirow{2}{*}{$\begin{array}{c}\text { Financial } \\
\text { sector }\end{array}$} & \multicolumn{2}{|c|}{ Overall } & \multirow{2}{*}{$\begin{array}{c}\text { Equity } \\
(8)\end{array}$} & \multirow{2}{*}{$\begin{array}{c}\text { Bond } \\
(9)\end{array}$} & \multirow{2}{*}{$\begin{array}{c}\begin{array}{c}\text { Financial } \\
\text { sector }\end{array} \\
(10)\end{array}$} \\
\hline & (1) & $(2)$ & & & & (6) & (7) & & & \\
\hline Asset flow s/GDP & $\begin{array}{l}0.057^{* *} \\
(0.023)\end{array}$ & & & & & $\begin{array}{l}0.003 \\
(0.014)\end{array}$ & & & & \\
\hline Liability flow s/GDP & $\begin{array}{l}0.043^{* *} \\
(0.020)\end{array}$ & & & & & $\begin{array}{l}0.017^{*} \\
(0.009)\end{array}$ & & & & \\
\hline Net FDI flow s/GDP & & $\begin{array}{c}0.006 \\
(0.060)\end{array}$ & $\begin{array}{c}-0.060^{* * *} \\
(0.022)\end{array}$ & $\begin{array}{l}-0.027 \\
(0.034)\end{array}$ & $\begin{array}{c}0.024 \\
(0.052)\end{array}$ & & $\begin{array}{l}0.001 \\
(0.035)\end{array}$ & $\begin{array}{l}-0.012 \\
(0.045)\end{array}$ & $\begin{array}{l}0.004 \\
(0.049)\end{array}$ & $\begin{array}{l}0.103^{*} \\
(0.062)\end{array}$ \\
\hline Net portfolio flow s/GDP & & $\begin{array}{l}0.091^{* * *} \\
(0.029)\end{array}$ & $\begin{array}{c}0.057 \\
(0.110)\end{array}$ & $\begin{array}{l}0.128^{* * *} \\
(0.046)\end{array}$ & $\begin{array}{l}0.074^{* * *} \\
(0.025)\end{array}$ & & $\begin{array}{l}0.000 \\
(0.016)\end{array}$ & $\begin{array}{l}0.010 \\
(0.019)\end{array}$ & $\begin{array}{l}0.009 \\
(0.019)\end{array}$ & $\begin{array}{l}-0.000 \\
(0.019)\end{array}$ \\
\hline Net other inv. flow s/GDP & & $\begin{array}{l}0.039^{* *} \\
(0.017)\end{array}$ & $\begin{array}{l}-0.166^{*} \\
(0.092)\end{array}$ & $\begin{array}{l}-0.035 \\
(0.045)\end{array}$ & $\begin{array}{c}0.041^{*} \\
(0.021)\end{array}$ & & $\begin{array}{l}0.033^{* * *} \\
(0.013)\end{array}$ & $\begin{array}{l}0.025^{*} \\
(0.015)\end{array}$ & $\begin{array}{l}0.031^{*} \\
(0.016)\end{array}$ & $\begin{array}{l}0.062^{* *} \\
(0.025)\end{array}$ \\
\hline Global market volatility & $\begin{array}{c}0.062 \\
(0.394)\end{array}$ & $\begin{array}{c}0.064 \\
(0.397)\end{array}$ & $\begin{array}{c}-0.539^{* * *} \\
(0.179)\end{array}$ & $\begin{array}{l}-0.084 \\
(0.334)\end{array}$ & $\begin{array}{c}0.030 \\
(0.455)\end{array}$ & $\begin{array}{l}0.122 \\
(0.273)\end{array}$ & $\begin{array}{l}0.064 \\
(0.283)\end{array}$ & $\begin{array}{l}-0.104 \\
(0.349)\end{array}$ & $\begin{array}{l}0.065 \\
(0.368)\end{array}$ & $\begin{array}{l}0.696 \\
(0.460)\end{array}$ \\
\hline US interest rate & $\begin{array}{c}-0.027 \\
(0.039)\end{array}$ & $\begin{array}{c}-0.016 \\
(0.037)\end{array}$ & $\begin{array}{l}-0.054 \\
(0.073)\end{array}$ & $\begin{array}{c}-0.123^{* * *} \\
(0.047)\end{array}$ & $\begin{array}{c}0.004 \\
(0.042)\end{array}$ & $\begin{array}{l}-0.030 \\
(0.044)\end{array}$ & $\begin{array}{l}-0.030 \\
(0.038)\end{array}$ & $\begin{array}{l}-0.043 \\
(0.048)\end{array}$ & $\begin{array}{l}-0.014 \\
(0.038)\end{array}$ & $\begin{array}{l}-0.018 \\
(0.033)\end{array}$ \\
\hline GFC & $\begin{array}{c}-4.887^{* * *} \\
(0.592)\end{array}$ & $\begin{array}{c}-4.787^{* * *} \\
(0.534)\end{array}$ & $\begin{array}{c}-4.075^{* * *} \\
(0.680)\end{array}$ & $\begin{array}{c}-4.673^{* * *} \\
(0.485)\end{array}$ & $\begin{array}{c}-4.627^{* * *} \\
(0.569)\end{array}$ & $\begin{array}{l}0.439 \\
(0.405)\end{array}$ & $\begin{array}{l}0.337 \\
(0.420)\end{array}$ & $\begin{array}{l}0.678 \\
(0.460)\end{array}$ & $\begin{array}{l}0.493 \\
(0.427)\end{array}$ & $\begin{array}{l}-6.458^{* * *} \\
(0.833)\end{array}$ \\
\hline Institutional quality & $\begin{array}{c}-6.818 \\
(4.290)\end{array}$ & $\begin{array}{c}-6.285 \\
(4.011)\end{array}$ & $\begin{array}{c}13.224 \\
(15.415)\end{array}$ & $\begin{array}{l}-0.317 \\
(7.539)\end{array}$ & $\begin{array}{l}-8.425^{* *} \\
(3.942)\end{array}$ & $\begin{array}{l}-5.299 \\
(3.630)\end{array}$ & $\begin{array}{l}-4.893 \\
(3.282)\end{array}$ & $\begin{array}{l}-5.160 \\
(3.577)\end{array}$ & $\begin{array}{l}-2.608 \\
(2.978)\end{array}$ & $\begin{array}{l}-5.636 \\
(6.556)\end{array}$ \\
\hline Country fixed effects & Yes & Yes & Yes & Yes & Yes & Yes & Yes & Yes & Yes & Yes \\
\hline Quarter effects & Yes & Yes & Yes & Yes & Yes & Yes & Yes & Yes & Yes & Yes \\
\hline Observations & 596 & 596 & 596 & 596 & 596 & 596 & 596 & 596 & 596 & 596 \\
\hline R-squared & 0.250 & 0.261 & 0.514 & 0.346 & 0.264 & 0.219 & 0.218 & 0.227 & 0.233 & 0.321 \\
\hline No. of countries & 17 & 17 & 17 & 17 & 17 & 17 & 17 & 17 & 17 & 17 \\
\hline
\end{tabular}


Table 8. Use of Policy Instruments and Risks, 2005Q1-2013Q4

\begin{tabular}{|c|c|c|c|c|c|c|}
\hline & $\begin{array}{c}\mathbf{F X} \\
\text { intervention } \\
(1)\end{array}$ & $\begin{array}{c}\text { Policy rate } \\
\text { tighte ning } \\
\text { (2) }\end{array}$ & $\begin{array}{c}\text { Macroprudential } \\
\text { tightening } \\
(3)\end{array}$ & $\begin{array}{c}\text { Inflow control } \\
\text { tightening } \\
(4)\end{array}$ & $\begin{array}{c}\text { Outflow control } \\
\text { easing } \\
(5)\end{array}$ & $\begin{array}{c}\text { Multiple } \\
\text { instruments } \\
(6)\end{array}$ \\
\hline \multirow[t]{2}{*}{ Change in REER } & $0.041^{* * *}$ & -0.005 & $0.019^{*}$ & $0.057^{* \star *}$ & $0.017^{* *}$ & $0.031^{* * *}$ \\
\hline & $(0.010)$ & $(0.012)$ & $(0.011)$ & $(0.008)$ & $(0.009)$ & $(0.009)$ \\
\hline \multirow[t]{2}{*}{ Output gap } & 0.028 & $0.305^{\star \star \star}$ & -0.054 & -0.123 & 0.045 & $0.119^{*}$ \\
\hline & $(0.041)$ & $(0.065)$ & $(0.037)$ & $(0.096)$ & $(0.047)$ & $(0.061)$ \\
\hline \multirow[t]{2}{*}{ Real domestic credit change } & 0.016 & $0.029^{* *}$ & $0.022^{* *}$ & $0.061^{* * *}$ & 0.010 & $0.031^{* * *}$ \\
\hline & $(0.011)$ & $(0.012)$ & $(0.009)$ & $(0.018)$ & $(0.013)$ & $(0.011)$ \\
\hline \multirow[t]{2}{*}{ Global market volatility } & -0.060 & -0.101 & -0.097 & -0.199 & $0.485^{* *}$ & 0.191 \\
\hline & $(0.177)$ & $(0.223)$ & $(0.286)$ & $(0.431)$ & $(0.232)$ & $(0.203)$ \\
\hline \multirow[t]{2}{*}{ Real U.S. interest rate } & $-0.058^{\star * \star}$ & 0.038 & -0.046 & $-0.131^{\star * *}$ & -0.038 & -0.015 \\
\hline & $(0.020)$ & $(0.024)$ & $(0.034)$ & $(0.039)$ & $(0.039)$ & $(0.021)$ \\
\hline \multirow[t]{2}{*}{ Commodity prices } & -0.221 & 0.007 & $0.881^{*}$ & 0.994 & $-0.737^{\star * \star}$ & 0.489 \\
\hline & $(0.546)$ & $(0.332)$ & $(0.463)$ & $(0.732)$ & $(0.219)$ & $(0.467)$ \\
\hline Country-fixed effects & Yes & Yes & Yes & Yes & Yes & Yes \\
\hline Quarter effects & Yes & Yes & Yes & Yes & Yes & Yes \\
\hline Observations & 540 & 540 & 540 & 540 & 540 & 540 \\
\hline Pseudo-R2 & 0.129 & 0.206 & 0.160 & 0.327 & 0.178 & 0.130 \\
\hline No. of countries & 15 & 15 & 15 & 15 & 15 & 15 \\
\hline
\end{tabular}




\section{Appendix: Data and Additional Estimation Results}

Figure A.1 Policy Responses in Large Outflows in EMEs, 2005Q1-2013Q4

(In percent of observations)

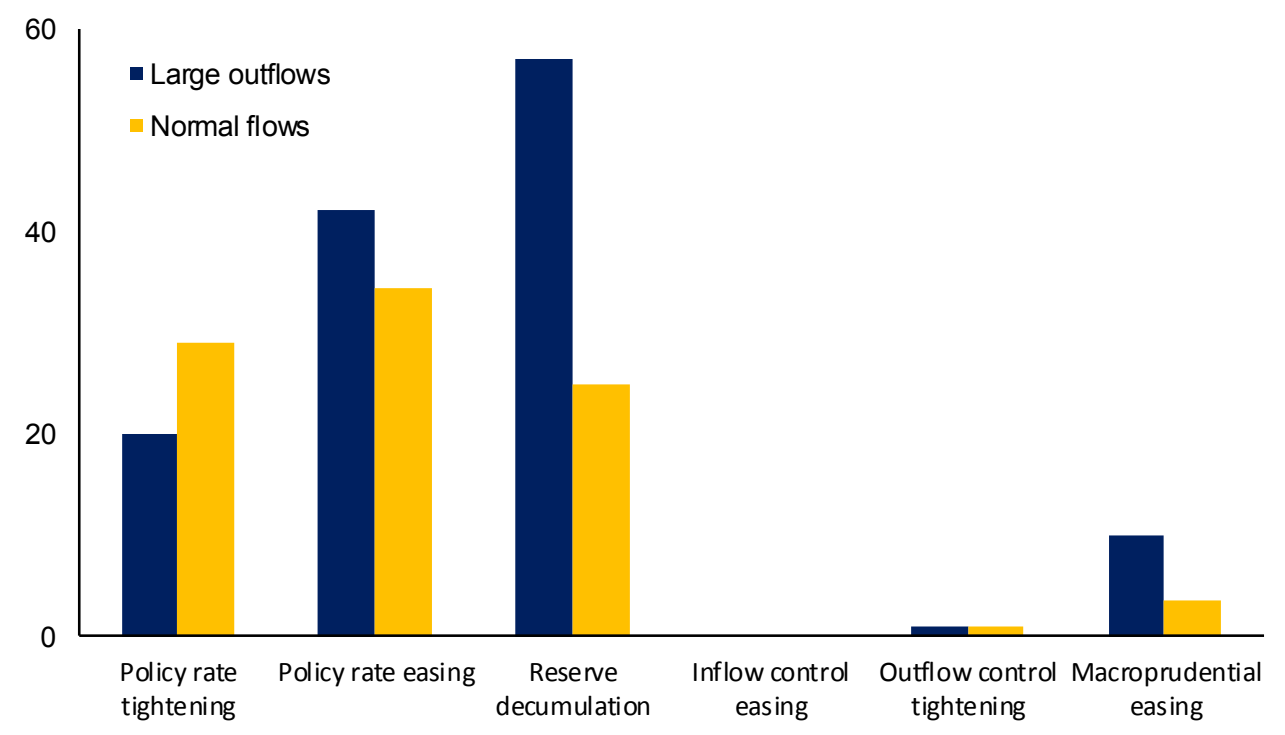

Source: Authors' estimates.

Note: Figure shows the percentage of large outflows/normal flow observations in which the respective policy instruments are deployed. Sample comprises those observations for which information on all policy instruments is available.

Table A.1 List of Countries in the Sample

\begin{tabular}{|c|c|c|c|c|c|}
\hline Country & Sample & Country & Sam ple & Country & Sample \\
\hline Albania & $\mathrm{b}$ & Estonia & $a, b, c, f$ & Pakistan & $\mathrm{b}$ \\
\hline Argentina & $a, b, d, e, f$ & Georgia & $a, b, c$ & Panama & $\mathrm{b}$ \\
\hline Armenia & $\mathrm{b}$ & Guatemala & $a, b, c, e$ & Peru & $a, b, c, e, f$ \\
\hline Belarus & $a, b, c, e$ & Hungary & $a, b, c, d, e$ & Philippines & $a, b, c, d, e, f$ \\
\hline Bosnia \& Herzegovina & $\mathrm{b}$ & India & $a, b, c, d, e$ & Poland & $a, b, c, d, e, f$ \\
\hline Brazil & $a, b, c, d, e, f$ & Indonesia & $a, b, c, d, e$ & Romania & $a, b, c, d, e, f$ \\
\hline Bulgaria & $a, b, c, f$ & Jamaica & $b, e$ & Russia & $a, b, c, f$ \\
\hline Chile & $a, b, c, d, e, f$ & Jordan & $b, c$ & Serbia & $a, b, c, e, f$ \\
\hline China & $b, c, e, f$ & Kazakhstan & $a, b, c$ & Slovak Rep. & $a, b, c$ \\
\hline Colombia & $b, c, d, e, f$ & Korea, Rep. & $a, b, c, d, f$ & South Africa & $a, b, c, d, f$ \\
\hline Costa Rica & $a, b, c, e$ & Latvia & $a, b, c, e, f$ & Sri Lanka & $a, b, c, e$ \\
\hline Croatia & $a, b, c, e, f$ & Lebanon & $a, b$ & Thailand & $a, b, c, e, f$ \\
\hline Czech Republic & $a, b, c, d, e$ & Lithuania & $a, b, c, e, f$ & Turkey & $a, b, c, d, e, f$ \\
\hline Dominican Republic & $b, c, e$ & Macedonia, FYR & $a, b, c, e$ & Ukraine & $a, b, c, f$ \\
\hline Ecuador & $a, b, c, e$ & Malaysia & $a, b, c, d, e$ & Uruguay & $b, c, e, f$ \\
\hline Egypt, Arab Rep. & $a, b, c$ & Mexico & $a, b, c, d, e$ & Venezuela & $b, c, e$ \\
\hline$\boxminus$ Salvador & $b, e$ & Morocco & $b, c, f$ & Vietnam & $\mathrm{b}$ \\
\hline
\end{tabular}

Notes: $\mathrm{a}=$ Included in real government consumption spending estimations; $\mathrm{b}=$ Included in FX intervention estimations; $\mathrm{c}$ $=$ Included in policy rate reaction functions; $d=$ Included in capital control estimations; $\mathrm{e}=$ Included in reserve requirement estimations; $f=$ Included in macroprudential policy estimations. 
Table A.2 Variable Description and Data Sources

\begin{tabular}{|c|c|c|}
\hline Variables & Description & Source \\
\hline Capital controls on inflows & $\begin{array}{l}\text { Binary variable (= } 1 \text { for tightening of inflow controls on } \\
\text { equity, debt, and bank flows; } 0 \text { otherwise) }\end{array}$ & $\begin{array}{l}\text { Authors' calculations based on } \\
\text { Ahmed et al. (2015) for } 2005-12 \text {, and } \\
\text { the IMF's AREAER for } 2013\end{array}$ \\
\hline Capital controls on outflows & $\begin{array}{l}\text { Binary variable (= } 1 \text { for relaxation of outflow controls } \\
\text { on equity, debt, and bank flows; } 0 \text { otherwise) }\end{array}$ & $\begin{array}{l}\text { Authors' calculations based on } \\
\text { information from IMF's AREAER }\end{array}$ \\
\hline Commodity prices & Index (in logs) & IMF's WEO database \\
\hline Real domestic credit & Domestic private sector credit deflated by CPI(in LC) & IFS database \\
\hline Real domestic credit growth & Year-on-year change in real domestic credit (in pct.) & Authors' calculations \\
\hline Foreign exchange reserves & Reserve flows (in billions of USD) & IFS database \\
\hline Foreign exchange reserves/GDP & $\begin{array}{l}\text { Reserve flows scaled by }(1 / 4)^{\star} \text { average annual GDP } \\
\text { over the sample period (in percent) }\end{array}$ & IFS database \\
\hline Exchange rate regime & $\begin{array}{l}\text { De facto exchange rate regime }(\text { fixed }=1 \text {, } \\
\text { intermediate }=2 \text {, floating }=3 \text { ) }\end{array}$ & Ghosh, Ostry, and Qureshi (2015) \\
\hline GDP current/constant prices & In billions of USD (or LC) & $\begin{array}{l}\text { IMF's WEO database, Haver } \\
\text { analytics. Observations are } \\
\text { seasonally adjusted for quarterly }\end{array}$ \\
\hline Global financial crisis (GFC) & $\begin{array}{l}\text { Binary variable (= 1for 2008Q4 and 2009Q1; } 0 \\
\text { otherwise) }\end{array}$ & Authors' calculations \\
\hline Inflation & Year-on-year change in $\mathrm{CPI}$ (in percent) & CPIobtained from IMF's INS database \\
\hline Institutional quality & Index (average of ICRG's 12 political risk components) & Political Risk Group \\
\hline Macroprudential measures & $\begin{array}{l}\text { Binary variable equal to } 1 \text { for tightening of } \\
\text { countercyclical capital requirements, dynamic loan } \\
\text { loss provisioning, caps on loan-to- value and debt- to- } \\
\text { income ratios, and limits on credit growth and } \\
\text { consumer loans; zero otherwise }\end{array}$ & $\begin{array}{l}\text { Authors' calculations based on } \\
\text { Akinciand Olmstead-Rumsey (2015) }\end{array}$ \\
\hline Net capital flows & $\begin{array}{l}\text { Net financial flows excluding financing items and } \\
\text { other investment liabilities of general government (in } \\
\text { USD bln.), i.e., the difference between IFS series } \\
\text { codes “..4995W.9” and "..4753ZB9" (in terms of } \\
\text { BPM5 presentation) }\end{array}$ & IMF's IFS database \\
\hline Net capital flows/GDP & $\begin{array}{l}\text { Net capital flows scaled by }(1 / 4)^{\star} \text { average annual GDP } \\
\text { over the sample period (in percent) }\end{array}$ & Authors' calculations \\
\hline Output gap & $\begin{array}{l}\text { Log difference between real GDP (seasonally } \\
\text { adjusted) and its trend (obtained from HP filter), in } \\
\text { percent of trend }\end{array}$ & Authors' calculations \\
\hline Policy rate & Policy rate or discount rate (in percent). & IMF's IFS database \\
\hline Real Effective Exchange Rate (REER) & Index & INS database \\
\hline REER change & Year-on-year change (in percent) & Authors' calculations \\
\hline Real government consumption spending & $\begin{array}{l}\text { Government consumption expenditure deflated by } \\
\text { GDP deflator (CPI where GDP deflator is unavailable); } \\
\text { seasonally adjusted }\end{array}$ & IFS database \\
\hline $\begin{array}{l}\text { Real govt. consumption spending } \\
\text { cyclical component }\end{array}$ & $\begin{array}{l}\text { Cyclical component of real government consumption } \\
\text { spending obtained from HP filter (in percent of trend) }\end{array}$ & Authors' calculations \\
\hline Reserve requirement & $\begin{array}{l}\text { Average of reserve requirements on local currency } \\
\text { demand, saving, and term deposits (in percent) }\end{array}$ & $\begin{array}{l}\text { Authors' calculations based on data } \\
\text { from Federico et al. (2014) }\end{array}$ \\
\hline U.S. interest rate & $\begin{array}{l}\text { U.S. 3-month Treasury Bill rate in real terms (in } \\
\text { percent). Computed as }[(1+\text { nominal interest } \\
\text { rate }) /(1+\text { expected inflation })]-1, \text { where expected } \\
\text { inflation is one-period ahead inflation }\end{array}$ & IMF's WEO and Bloomberg \\
\hline VIX & $\begin{array}{l}\text { Chicago Board Options Exchange Market Volatility } \\
\text { Index (in logs) }\end{array}$ & Bloomberg \\
\hline
\end{tabular}


Table A.3 Tightening of Macroprudential Policies in Selected EMEs, 2005Q1-2013Q4

\begin{tabular}{|c|c|c|c|c|c|c|c|}
\hline & $\begin{array}{c}\text { Countercylical } \\
\text { capital requirement }\end{array}$ & $\begin{array}{c}\text { Credit } \\
\text { growth lim it }\end{array}$ & $\begin{array}{l}\text { Consumer } \\
\text { loan lim it }\end{array}$ & $\begin{array}{l}\text { Loan loss } \\
\text { provis ioning }\end{array}$ & $\begin{array}{c}\text { Debt-to- } \\
\text { income cap }\end{array}$ & $\begin{array}{l}\text { Loan-to- } \\
\text { value cap }\end{array}$ & $\begin{array}{c}\text { Reserve } \\
\text { requirement }\end{array}$ \\
\hline Argentina- & & & & & & & 2 \\
\hline Belarus & & & & & & & 2 \\
\hline Brazil & 3 & & 1 & & & & 4 \\
\hline Bulgaria & 1 & 2 & & 1 & & 2 & \\
\hline China & 1 & & & 1 & & 5 & 5 \\
\hline Colombia & 1 & & & 2 & & & 1 \\
\hline Costa Rica & & & & & & & 1 \\
\hline Croatia & 2 & 1 & & 1 & 1 & 1 & 5 \\
\hline Guatemala & & & & & & & 1 \\
\hline Hungary & & & 1 & & 1 & 1 & 1 \\
\hline India & 2 & & & 4 & & 2 & 9 \\
\hline Indonesia & & & 1 & & & 2 & 3 \\
\hline Korea & & & & 1 & 7 & 4 & \\
\hline Latvia & & & & & 2 & 1 & 2 \\
\hline Macedonia & & & & & & & 1 \\
\hline Mexico & & & & 2 & & & \\
\hline Peru & 1 & & & 2 & & & 5 \\
\hline Philippines & & & & & & & 3 \\
\hline Poland & 1 & & & & 2 & 2 & 1 \\
\hline Romania & 1 & 1 & & 3 & 1 & 1 & 1 \\
\hline Russia & 4 & & & 1 & & & \\
\hline Serbia & & & & 1 & & 3 & \\
\hline Sri Lanka & & & & & & & 1 \\
\hline Thailand & & & 2 & & & & \\
\hline Turkey & 3 & 2 & 3 & 2 & & & 5 \\
\hline Ukraine & & & & 1 & & & \\
\hline Uruguay & & & & 1 & & & 3 \\
\hline Venezuela & & & & & & & 1 \\
\hline Total & 20 & 6 & 8 & 23 & 14 & 24 & 57 \\
\hline
\end{tabular}

Table A.4 Changes in Capital Controls in EMEs, 2005Q1-2013Q4

\begin{tabular}{|c|c|c|c|c|c|c|}
\hline & \multicolumn{3}{|c|}{ Tightening of inflow controls } & \multicolumn{3}{|c|}{ Relaxation of outflow controls } \\
\hline & Equity & Bond & $\begin{array}{c}\text { Financial } \\
\text { sector }\end{array}$ & Equity & Bond & $\begin{array}{c}\text { Financial } \\
\text { sector }\end{array}$ \\
\hline Argentina & 3 & 4 & 2 & & & \\
\hline Brazil & 2 & 3 & 7 & 3 & 1 & \\
\hline Chile & & & & 2 & 3 & \\
\hline Colombia & 2 & 2 & 1 & 2 & 2 & \\
\hline Hungary & & & & 1 & 1 & 1 \\
\hline India & & & 2 & 5 & 4 & 1 \\
\hline Indonesia & & 2 & 5 & & & \\
\hline Korea & & 3 & 7 & 1 & 1 & 3 \\
\hline Malaysia & & & & 5 & 3 & 3 \\
\hline Mexico & & & 1 & & & \\
\hline Philippines & & & 1 & 6 & 6 & 2 \\
\hline Romania & & & 3 & & & \\
\hline Thailand & & 2 & 1 & 9 & 10 & 2 \\
\hline Turkey & & & 8 & 4 & 4 & \\
\hline South Africa & & & & 6 & 6 & 2 \\
\hline Total & 7 & 16 & 38 & 38 & 35 & 12 \\
\hline
\end{tabular}


Table A.5 Net Capital Flows and FX Intervention in Selected EMEs

\begin{tabular}{|c|c|c|c|c|c|c|c|}
\hline & $\begin{array}{l}\text { Net capital } \\
\text { flow s/GDP }\end{array}$ & $\begin{array}{l}\text { US interest } \\
\text { rate }\end{array}$ & $\begin{array}{c}\text { Global market } \\
\text { volatility }\end{array}$ & $\begin{array}{l}\text { Commodity } \\
\text { prices }\end{array}$ & GFC & Obs. & $\mathrm{R}^{2}$ \\
\hline \multicolumn{8}{|l|}{ Asia } \\
\hline India & $\begin{array}{l}0.817^{* * *} \\
(0.188)\end{array}$ & $\begin{array}{c}0.147 \\
(0.105)\end{array}$ & $\begin{array}{c}0.449 \\
(1.374)\end{array}$ & $\begin{array}{c}-6.796^{\star * *} \\
(1.884)\end{array}$ & $\begin{array}{c}0.041 \\
(2.485)\end{array}$ & 36 & 0.610 \\
\hline Indonesia & $\begin{array}{l}0.726^{* * *} \\
(0.177)\end{array}$ & $\begin{array}{c}0.012 \\
(0.124)\end{array}$ & $\begin{array}{l}3.841^{*} \\
(2.206)\end{array}$ & $\begin{array}{c}-6.755^{* *} \\
(2.539)\end{array}$ & $\begin{array}{l}-5.100 \\
(3.097)\end{array}$ & 36 & 0.442 \\
\hline Korea, Rep. & $\begin{array}{l}0.633^{* * *} \\
(0.132)\end{array}$ & $\begin{array}{c}-0.397^{* * *} \\
(0.118)\end{array}$ & $\begin{array}{l}-1.223 \\
(1.974)\end{array}$ & $\begin{array}{l}-0.433 \\
(2.626)\end{array}$ & $\begin{array}{l}-2.263 \\
(4.180)\end{array}$ & 36 & 0.716 \\
\hline Malaysia & $\begin{array}{l}0.894^{* * *} \\
(0.092)\end{array}$ & $\begin{array}{l}-0.354 \\
(0.282)\end{array}$ & $\begin{array}{l}-0.643 \\
(2.665)\end{array}$ & $\begin{array}{c}18.034^{* * *} \\
(3.256)\end{array}$ & $\begin{array}{c}4.682 \\
(6.155)\end{array}$ & 20 & 0.966 \\
\hline Philippines & $\begin{array}{l}0.591^{* * *} \\
(0.153)\end{array}$ & $\begin{array}{c}-0.539^{* * *} \\
(0.144)\end{array}$ & $\begin{array}{c}0.255 \\
(1.701)\end{array}$ & $\begin{array}{c}2.161 \\
(2.310)\end{array}$ & $\begin{array}{c}2.143 \\
(3.003)\end{array}$ & 36 & 0.702 \\
\hline Thailand & $\begin{array}{l}0.636^{* * *} \\
(0.104)\end{array}$ & $\begin{array}{l}-0.190 \\
(0.202)\end{array}$ & $\begin{array}{l}9.180^{* * *} \\
(2.758)\end{array}$ & $\begin{array}{l}-8.069^{* *} \\
(3.395)\end{array}$ & $\begin{array}{l}-7.171 \\
(5.309)\end{array}$ & 36 & 0.726 \\
\hline \multicolumn{8}{|l|}{ Europe } \\
\hline Czech Rep. & $\begin{array}{l}0.648^{* * *} \\
(0.207)\end{array}$ & $\begin{array}{l}-0.235 \\
(0.142)\end{array}$ & $\begin{array}{l}-1.489 \\
(2.132)\end{array}$ & $\begin{array}{c}1.334 \\
(3.150)\end{array}$ & $\begin{array}{c}1.372 \\
(3.350)\end{array}$ & 36 & 0.598 \\
\hline Hungary & $\begin{array}{l}0.737^{* * *} \\
(0.184)\end{array}$ & $\begin{array}{l}-0.620 \\
(0.365)\end{array}$ & $\begin{array}{c}4.220 \\
(3.955)\end{array}$ & $\begin{array}{c}2.398 \\
(5.061)\end{array}$ & $\begin{array}{c}23.188^{* * *} \\
(5.922)\end{array}$ & 36 & 0.698 \\
\hline Poland & $\begin{array}{l}0.483^{* * *} \\
(0.095)\end{array}$ & $\begin{array}{c}-0.456^{\star *} \\
(0.179)\end{array}$ & $\begin{array}{c}-0.908 \\
(1.596)\end{array}$ & $\begin{array}{l}-2.411 \\
(1.870)\end{array}$ & $\begin{array}{l}-5.159 \\
(3.656)\end{array}$ & 36 & 0.737 \\
\hline Romania & $\begin{array}{l}0.293^{* * *} \\
(0.099)\end{array}$ & $\begin{array}{c}-0.495^{\star *} \\
(0.213)\end{array}$ & $\begin{array}{l}-2.122 \\
(3.075)\end{array}$ & $\begin{array}{l}-5.676 \\
(3.768)\end{array}$ & $\begin{array}{l}-4.255 \\
(6.092)\end{array}$ & 36 & 0.516 \\
\hline Russia & $\begin{array}{l}0.942^{* * *} \\
(0.076)\end{array}$ & $\begin{array}{l}0.418^{* * *} \\
(0.113)\end{array}$ & $\begin{array}{l}3.617^{*} \\
(2.061)\end{array}$ & $\begin{array}{c}1.715 \\
(2.865)\end{array}$ & $\begin{array}{c}10.745^{\star *} \\
(3.380)\end{array}$ & 36 & 0.954 \\
\hline Turkey & $\begin{array}{l}0.532^{* * *} \\
(0.101)\end{array}$ & $\begin{array}{c}0.014 \\
(0.115)\end{array}$ & $\begin{array}{l}-0.571 \\
(1.615)\end{array}$ & $\begin{array}{c}-5.563^{* *} \\
(2.033)\end{array}$ & $\begin{array}{c}2.502 \\
(2.104)\end{array}$ & 36 & 0.644 \\
\hline \multicolumn{8}{|l|}{ Latin America } \\
\hline Brazil & $\begin{array}{c}0.889^{* * *} \\
(0.117)\end{array}$ & $\begin{array}{c}0.150 \\
(0.092)\end{array}$ & $\begin{array}{c}0.294 \\
(1.063)\end{array}$ & $\begin{array}{c}-6.242^{* * *} \\
(1.523)\end{array}$ & $\begin{array}{c}-0.498 \\
(1.927)\end{array}$ & 36 & 0.796 \\
\hline Chile & $\begin{array}{l}0.486^{* * *} \\
(0.115)\end{array}$ & $\begin{array}{c}0.178 \\
(0.170)\end{array}$ & $\begin{array}{l}4.981^{\text {** }} \\
(2.008)\end{array}$ & $\begin{array}{l}-4.138 \\
(3.280)\end{array}$ & $\begin{array}{c}-9.573^{* *} \\
(3.739)\end{array}$ & 36 & 0.615 \\
\hline Colombia & $\begin{array}{c}0.451^{* * *} \\
(0.099)\end{array}$ & $\begin{array}{c}0.053 \\
(0.050)\end{array}$ & $\begin{array}{l}-0.746 \\
(0.612)\end{array}$ & $\begin{array}{l}-0.287 \\
(1.185)\end{array}$ & $\begin{array}{c}-0.107 \\
(1.015)\end{array}$ & 36 & 0.765 \\
\hline Mexico & $\begin{array}{c}0.097 \\
(0.095)\end{array}$ & $\begin{array}{l}-0.032 \\
(0.056)\end{array}$ & $\begin{array}{c}1.299 \\
(1.406)\end{array}$ & $\begin{array}{c}1.513 \\
(1.502)\end{array}$ & $\begin{array}{c}-4.981^{* *} \\
(1.920)\end{array}$ & 36 & 0.508 \\
\hline Peru & $\begin{array}{l}0.815^{\star \star \star} \\
(0.106)\end{array}$ & $\begin{array}{l}-0.105 \\
(0.268)\end{array}$ & $\begin{array}{c}1.254 \\
(2.536)\end{array}$ & $\begin{array}{l}-7.098^{*} \\
(3.722)\end{array}$ & $\begin{array}{c}-7.609^{* *} \\
(3.585)\end{array}$ & 36 & 0.806 \\
\hline \multicolumn{8}{|c|}{ Middle East and Africa } \\
\hline Jordan & $\begin{array}{c}0.880^{* * *} \\
(0.218)\end{array}$ & $\begin{array}{l}-0.261 \\
(0.456)\end{array}$ & $\begin{array}{c}-2.335 \\
(10.228)\end{array}$ & $\begin{array}{l}-19.567^{*} \\
(10.341)\end{array}$ & $\begin{array}{c}7.071 \\
(15.717)\end{array}$ & 36 & 0.570 \\
\hline Morocco & $\begin{array}{l}0.743^{* *} \\
(0.271)\end{array}$ & $\begin{array}{c}0.088 \\
(0.212)\end{array}$ & $\begin{array}{l}-3.082 \\
(2.722)\end{array}$ & $\begin{array}{c}-14.706^{* * *} \\
(4.833)\end{array}$ & $\begin{array}{l}-6.188 \\
(5.031)\end{array}$ & 36 & 0.519 \\
\hline South Africa & $\begin{array}{c}0.135^{*} \\
(0.078)\end{array}$ & $\begin{array}{l}-0.008 \\
(0.098)\end{array}$ & $\begin{array}{c}0.467 \\
(0.861)\end{array}$ & $\begin{array}{c}-2.077 \\
(1.385)\end{array}$ & $\begin{array}{l}-1.427 \\
(1.652)\end{array}$ & 36 & 0.289 \\
\hline
\end{tabular}

Note: Dependent variable is change in reserves (excluding valuation changes) in percent of GDP. See Appendix for description of variables and data sources. All regressions include a constant and quarter effects. Robust standard erro rs reported in parentheses. ${ }^{* * *},{ }^{* *}$ and ${ }^{*}$ indicate statistical significance at the 1 , 5 and 10 percent levels, respectively. 
Table A.6 Net Capital Flows and Policy Interest Rate in Selected EMEs

\begin{tabular}{|c|c|c|c|c|c|c|c|c|}
\hline & $\begin{array}{l}\text { Net capital } \\
\text { flow s/GDP }\end{array}$ & $\begin{array}{c}\text { Policy rate } \\
\text { (lagged) }\end{array}$ & $\begin{array}{l}\text { US interest } \\
\text { rate }\end{array}$ & $\begin{array}{c}\text { Global market } \\
\text { volatility }\end{array}$ & $\begin{array}{l}\text { Commodity } \\
\text { prices }\end{array}$ & GFC & Obs. & $\mathrm{R}^{2}$ \\
\hline \multicolumn{9}{|l|}{ Asia } \\
\hline India & $\begin{array}{l}-0.013 \\
(0.017)\end{array}$ & $\begin{array}{l}0.880^{* * *} \\
(0.064)\end{array}$ & $\begin{array}{c}0.004 \\
(0.015)\end{array}$ & $\begin{array}{l}-0.111 \\
(0.217)\end{array}$ & $\begin{array}{l}0.581^{*} \\
(0.317)\end{array}$ & $\begin{array}{c}-1.567^{* * *} \\
(0.467)\end{array}$ & 36 & 0.942 \\
\hline Indonesia & $\begin{array}{l}-0.037 \\
(0.024)\end{array}$ & $\begin{array}{l}0.817^{* * *} \\
(0.090)\end{array}$ & $\begin{array}{c}0.025 \\
(0.046)\end{array}$ & $\begin{array}{l}-0.833^{*} \\
(0.441)\end{array}$ & $\begin{array}{l}-0.120 \\
(0.597)\end{array}$ & $\begin{array}{c}0.266 \\
(0.557)\end{array}$ & 36 & 0.883 \\
\hline Korea, Rep. & $\begin{array}{l}0.035^{\star * *} \\
(0.012)\end{array}$ & $\begin{array}{l}0.995^{* * *} \\
(0.037)\end{array}$ & $\begin{array}{c}0.006 \\
(0.013)\end{array}$ & $\begin{array}{l}-0.155 \\
(0.118)\end{array}$ & $\begin{array}{c}0.250 \\
(0.190)\end{array}$ & $\begin{array}{c}-1.124^{* * *} \\
(0.299)\end{array}$ & 36 & 0.968 \\
\hline Malaysia & $\begin{array}{l}-0.002 \\
(0.004)\end{array}$ & $\begin{array}{l}1.033^{* * *} \\
(0.124)\end{array}$ & $\begin{array}{c}0.011 \\
(0.013)\end{array}$ & $\begin{array}{c}0.038 \\
(0.237)\end{array}$ & $\begin{array}{l}-0.169 \\
(0.294)\end{array}$ & $\begin{array}{l}-0.916^{*} \\
(0.456)\end{array}$ & 20 & 0.927 \\
\hline Philippines & $\begin{array}{l}0.021^{* *} \\
(0.009)\end{array}$ & $\begin{array}{l}0.888^{* * *} \\
(0.066)\end{array}$ & $\begin{array}{l}0.105^{\star * *} \\
(0.012)\end{array}$ & $\begin{array}{c}0.308 \\
(0.186)\end{array}$ & $\begin{array}{l}0.727^{\star *} \\
(0.325)\end{array}$ & $\begin{array}{l}-0.344 \\
(0.373)\end{array}$ & 36 & 0.893 \\
\hline Thailand & $\begin{array}{l}0.010^{*} \\
(0.005)\end{array}$ & $\begin{array}{l}0.901^{* * *} \\
(0.070)\end{array}$ & $\begin{array}{c}0.013 \\
(0.022)\end{array}$ & $\begin{array}{l}-0.170 \\
(0.205)\end{array}$ & $\begin{array}{l}-0.077 \\
(0.269)\end{array}$ & $\begin{array}{c}-0.953^{* * *} \\
(0.280)\end{array}$ & 36 & 0.913 \\
\hline \multicolumn{9}{|l|}{ Europe } \\
\hline Czech Rep. & $\begin{array}{l}-0.002 \\
(0.005)\end{array}$ & $\begin{array}{l}1.059^{* * *} \\
(0.037)\end{array}$ & $\begin{array}{l}-0.009 \\
(0.020)\end{array}$ & $\begin{array}{l}-0.210^{* *} \\
(0.098)\end{array}$ & $\begin{array}{c}0.182 \\
(0.188)\end{array}$ & $\begin{array}{l}-0.589^{*} \\
(0.299)\end{array}$ & 36 & 0.966 \\
\hline Hungary & $\begin{array}{c}0.011 \\
(0.014)\end{array}$ & $\begin{array}{l}0.847^{* * *} \\
(0.117)\end{array}$ & $\begin{array}{c}0.069 \\
(0.051)\end{array}$ & $\begin{array}{c}0.589 \\
(0.433)\end{array}$ & $\begin{array}{c}0.331 \\
(0.516)\end{array}$ & $\begin{array}{c}0.383 \\
(0.644)\end{array}$ & 36 & 0.850 \\
\hline Poland & $\begin{array}{l}0.036^{* * *} \\
(0.009)\end{array}$ & $\begin{array}{l}0.895^{\star * *} \\
(0.062)\end{array}$ & $\begin{array}{c}0.027 \\
(0.016)\end{array}$ & $\begin{array}{c}0.089 \\
(0.180)\end{array}$ & $\begin{array}{c}0.414 \\
(0.279)\end{array}$ & $\begin{array}{l}-0.648^{* *} \\
(0.267)\end{array}$ & 36 & 0.902 \\
\hline Romania & $\begin{array}{l}0.040^{* *} \\
(0.017)\end{array}$ & $\begin{array}{l}0.593^{* * *} \\
(0.150)\end{array}$ & $\begin{array}{c}0.075 \\
(0.050)\end{array}$ & $\begin{array}{l}0.944^{*} \\
(0.528)\end{array}$ & $\begin{array}{l}-0.356 \\
(0.957)\end{array}$ & $\begin{array}{c}0.103 \\
(0.690)\end{array}$ & 36 & 0.881 \\
\hline Russia & $\begin{array}{c}0.007 \\
(0.006)\end{array}$ & $\begin{array}{l}0.854^{* * *} \\
(0.103)\end{array}$ & $\begin{array}{c}0.003 \\
(0.025)\end{array}$ & $\begin{array}{c}0.249 \\
(0.342)\end{array}$ & $\begin{array}{l}-0.042 \\
(0.416)\end{array}$ & $\begin{array}{c}0.947^{\star} \\
(0.519)\end{array}$ & 36 & 0.910 \\
\hline Turkey & $\begin{array}{l}-0.064 \\
(0.055)\end{array}$ & $\begin{array}{l}0.966^{* * *} \\
(0.053)\end{array}$ & $\begin{array}{c}0.161 \\
(0.097)\end{array}$ & $\begin{array}{l}-0.611 \\
(0.827)\end{array}$ & $\begin{array}{c}1.922^{*} \\
(1.073)\end{array}$ & $\begin{array}{l}-1.354 \\
(1.227)\end{array}$ & 36 & 0.959 \\
\hline \multicolumn{9}{|l|}{ Latin America } \\
\hline Brazil & $\begin{array}{l}-0.017 \\
(0.053)\end{array}$ & $\begin{array}{l}0.962^{\star * *} \\
(0.070)\end{array}$ & $\begin{array}{c}0.020 \\
(0.055)\end{array}$ & $\begin{array}{l}-0.154 \\
(0.602)\end{array}$ & $\begin{array}{c}0.876 \\
(1.016)\end{array}$ & $\begin{array}{c}-0.503 \\
(1.308)\end{array}$ & 36 & 0.925 \\
\hline Chile & $\begin{array}{c}0.001 \\
(0.020)\end{array}$ & $\begin{array}{l}0.869^{* * *} \\
(0.090)\end{array}$ & $\begin{array}{c}0.095^{*} \\
(0.047)\end{array}$ & $\begin{array}{l}-0.309 \\
(0.571)\end{array}$ & $\begin{array}{c}1.066 \\
(0.891)\end{array}$ & $\begin{array}{l}-1.827 \\
(2.065)\end{array}$ & 36 & 0.841 \\
\hline Colombia & $\begin{array}{c}-0.041 \\
(0.056)\end{array}$ & $\begin{array}{l}1.030^{* * *} \\
(0.042)\end{array}$ & $\begin{array}{c}0.031 \\
(0.029)\end{array}$ & $\begin{array}{c}-0.760 \\
(0.573)\end{array}$ & $\begin{array}{c}1.200 \\
(0.806)\end{array}$ & $\begin{array}{l}-0.384 \\
(1.053)\end{array}$ & 36 & 0.943 \\
\hline Mexico & $\begin{array}{c}0.022 \\
(0.019)\end{array}$ & $\begin{array}{l}1.039^{* * *} \\
(0.051)\end{array}$ & $\begin{array}{c}0.031^{*} \\
(0.015)\end{array}$ & $\begin{array}{l}-0.124 \\
(0.462)\end{array}$ & $\begin{array}{c}0.615 \\
(0.645)\end{array}$ & $\begin{array}{l}-0.239 \\
(0.749)\end{array}$ & 36 & 0.942 \\
\hline Peru & $\begin{array}{c}0.013 \\
(0.016)\end{array}$ & $\begin{array}{l}0.724^{* * *} \\
(0.128)\end{array}$ & $\begin{array}{l}0.074^{* *} \\
(0.033)\end{array}$ & $\begin{array}{c}-0.831 \\
(0.493)\end{array}$ & $\begin{array}{l}1.361^{* *} \\
(0.659)\end{array}$ & $\begin{array}{c}1.808^{*} \\
(0.993)\end{array}$ & 36 & 0.838 \\
\hline \multicolumn{9}{|c|}{ Middle East and Africa } \\
\hline Jordan & $\begin{array}{c}-0.003 \\
(0.003)\end{array}$ & $\begin{array}{l}0.898^{* * *} \\
(0.051)\end{array}$ & $\begin{array}{c}0.023 \\
(0.014)\end{array}$ & $\begin{array}{c}-0.491^{* *} \\
(0.179)\end{array}$ & $\begin{array}{c}-0.194 \\
(0.223)\end{array}$ & $\begin{array}{c}0.050 \\
(0.256)\end{array}$ & 36 & 0.949 \\
\hline Morocco & $\begin{array}{l}-0.001 \\
(0.002)\end{array}$ & $\begin{array}{l}0.885^{* * *} \\
(0.141)\end{array}$ & $\begin{array}{l}0.012^{* *} \\
(0.004)\end{array}$ & $\begin{array}{c}0.063^{*} \\
(0.034)\end{array}$ & $\begin{array}{l}-0.015 \\
(0.082)\end{array}$ & $\begin{array}{c}-0.164^{* * *} \\
(0.057)\end{array}$ & 36 & 0.845 \\
\hline South Africa & $\begin{array}{c}0.016 \\
(0.023)\end{array}$ & $\begin{array}{l}1.113^{\star * *} \\
(0.055)\end{array}$ & $\begin{array}{c}0.025 \\
(0.034)\end{array}$ & $\begin{array}{c}-0.895^{\star *} \\
(0.423)\end{array}$ & $\begin{array}{l}0.982^{\star *} \\
(0.469)\end{array}$ & $\begin{array}{c}-0.174 \\
(0.705)\end{array}$ & 36 & 0.966 \\
\hline
\end{tabular}

Note: Dependent variable is central bank policy rate (in percent). Net capital flows are in percent of GDP. See Appendix for the description of variables and data sources. All regressions include a constant and quarter effects. Robust standard errors reported in parentheses. ${ }^{* \star *},{ }^{* *}$ and * indicate statistical significance at the 1,5 and 10 percent levels, respectively. 
Table A.7 Net Capital Flows and Policy Interest Rate in EMEs: Additional Covariates

\begin{tabular}{|c|c|c|c|c|c|c|c|c|c|c|c|}
\hline & $\begin{array}{l}\text { Net capital } \\
\text { flow s/GDP }\end{array}$ & $\begin{array}{c}\text { Policy rate } \\
\text { (lagged) }\end{array}$ & $\begin{array}{l}\text { US interest } \\
\text { rate }\end{array}$ & $\begin{array}{c}\text { Global } \\
\text { market vol. }\end{array}$ & $\begin{array}{l}\text { Commodity } \\
\text { prices }\end{array}$ & GFC & $\begin{array}{c}\text { Output } \\
\text { gap }\end{array}$ & $\begin{array}{l}\text { Change } \\
\text { in REER }\end{array}$ & Inflation & Obs. & $\mathrm{R}^{2}$ \\
\hline \multicolumn{12}{|l|}{ Asia } \\
\hline India & $\begin{array}{l}-0.000 \\
(0.014)\end{array}$ & $\begin{array}{c}0.677^{* * *} \\
(0.086)\end{array}$ & $\begin{array}{c}0.017 \\
(0.015)\end{array}$ & $\begin{array}{c}-0.224 \\
(0.166)\end{array}$ & $\begin{array}{l}1.125^{* *} \\
(0.535)\end{array}$ & $\begin{array}{l}-0.652 \\
(0.422)\end{array}$ & $\begin{array}{c}0.108^{*} \\
(0.055)\end{array}$ & $\begin{array}{l}-0.015 \\
(0.010)\end{array}$ & $\begin{array}{c}-0.054 \\
(0.049)\end{array}$ & 36 & 0.966 \\
\hline Indonesia & $\begin{array}{c}-0.046^{* *} \\
(0.017)\end{array}$ & $\begin{array}{c}0.445^{\star \star \star} \\
(0.092)\end{array}$ & $\begin{array}{l}-0.015 \\
(0.027)\end{array}$ & $\begin{array}{l}-0.304 \\
(0.311)\end{array}$ & $\begin{array}{l}-0.642 \\
(0.538)\end{array}$ & $\begin{array}{l}-0.611 \\
(0.501)\end{array}$ & $\begin{array}{c}0.136 \\
(0.237)\end{array}$ & $\begin{array}{c}0.005 \\
(0.016)\end{array}$ & $\begin{array}{c}0.283^{* * *} \\
(0.040)\end{array}$ & 36 & 0.964 \\
\hline Korea, Rep. & $\begin{array}{c}0.024^{*} \\
(0.012)\end{array}$ & $\begin{array}{c}0.867^{* * *} \\
(0.083)\end{array}$ & $\begin{array}{c}0.011 \\
(0.011)\end{array}$ & $\begin{array}{c}-0.293 \\
(0.223)\end{array}$ & $\begin{array}{l}-0.110 \\
(0.251)\end{array}$ & $\begin{array}{c}-0.946^{* *} \\
(0.338)\end{array}$ & $\begin{array}{l}0.109^{* *} \\
(0.041)\end{array}$ & $\begin{array}{l}-0.005 \\
(0.007)\end{array}$ & $\begin{array}{c}0.048 \\
(0.062)\end{array}$ & 36 & 0.974 \\
\hline Malaysia & $\begin{array}{c}0.000 \\
(0.004)\end{array}$ & $\begin{array}{c}0.675^{\star \star *} \\
(0.160)\end{array}$ & $\begin{array}{c}0.001 \\
(0.015)\end{array}$ & $\begin{array}{c}0.232 \\
(0.201)\end{array}$ & $\begin{array}{l}-0.513 \\
(0.343)\end{array}$ & $\begin{array}{l}-0.464 \\
(0.375)\end{array}$ & $\begin{array}{c}0.097^{*} \\
(0.041)\end{array}$ & $\begin{array}{c}0.057^{* * *} \\
(0.015)\end{array}$ & $\begin{array}{l}-0.007 \\
(0.036)\end{array}$ & 20 & 0.977 \\
\hline Philippines & $\begin{array}{c}0.015^{\star} \\
(0.008)\end{array}$ & $\begin{array}{c}0.722^{* * *} \\
(0.096)\end{array}$ & $\begin{array}{l}0.068^{* *} \\
(0.024)\end{array}$ & $\begin{array}{c}0.179 \\
(0.202)\end{array}$ & $\begin{array}{c}0.401 \\
(0.307)\end{array}$ & $\begin{array}{l}-0.398 \\
(0.406)\end{array}$ & $\begin{array}{c}0.027 \\
(0.083)\end{array}$ & $\begin{array}{c}0.007 \\
(0.022)\end{array}$ & $\begin{array}{c}0.125^{\star} \\
(0.073)\end{array}$ & 36 & 0.912 \\
\hline Thailand & $\begin{array}{c}0.010 \\
(0.007)\end{array}$ & $\begin{array}{l}0.860^{* * *} \\
(0.055)\end{array}$ & $\begin{array}{l}-0.011 \\
(0.016)\end{array}$ & $\begin{array}{l}-0.168 \\
(0.216)\end{array}$ & $\begin{array}{l}-0.313 \\
(0.221)\end{array}$ & $\begin{array}{c}-0.814^{* * *} \\
(0.246)\end{array}$ & $\begin{array}{c}-0.021 \\
(0.024)\end{array}$ & $\begin{array}{c}-0.009 \\
(0.013)\end{array}$ & $\begin{array}{l}0.139^{* * *} \\
(0.030)\end{array}$ & 36 & 0.960 \\
\hline \multicolumn{12}{|l|}{ Europe } \\
\hline Czech Rep. & $\begin{array}{c}-0.003 \\
(0.005)\end{array}$ & $\begin{array}{l}0.979^{* * *} \\
(0.109)\end{array}$ & $\begin{array}{l}-0.006 \\
(0.018)\end{array}$ & $\begin{array}{l}-0.099 \\
(0.102)\end{array}$ & $\begin{array}{c}-0.112 \\
(0.392)\end{array}$ & $\begin{array}{c}-0.684^{* *} \\
(0.283)\end{array}$ & $\begin{array}{c}0.072^{*} \\
(0.038)\end{array}$ & $\begin{array}{c}-0.014 \\
(0.012)\end{array}$ & $\begin{array}{c}0.007 \\
(0.050)\end{array}$ & 36 & 0.971 \\
\hline Hungary & $\begin{array}{c}-0.001 \\
(0.012)\end{array}$ & $\begin{array}{l}0.702^{* * *} \\
(0.087)\end{array}$ & $\begin{array}{c}0.040 \\
(0.026)\end{array}$ & $\begin{array}{c}0.813^{* * *} \\
(0.268)\end{array}$ & $\begin{array}{l}-0.329 \\
(0.335)\end{array}$ & $\begin{array}{c}0.375 \\
(0.516)\end{array}$ & $\begin{array}{c}0.187^{* * *} \\
(0.044)\end{array}$ & $\begin{array}{c}-0.050^{* * *} \\
(0.014)\end{array}$ & $\begin{array}{c}{ }^{*} 0.219^{\star * *} \\
(0.058)\end{array}$ & 36 & 0.959 \\
\hline Poland & $\begin{array}{c}0.007 \\
(0.007)\end{array}$ & $\begin{array}{l}0.697^{\star \star *} \\
(0.072)\end{array}$ & $\begin{array}{c}0.002 \\
(0.013)\end{array}$ & $\begin{array}{c}-0.345^{\star *} \\
(0.164)\end{array}$ & $\begin{array}{c}-0.376 \\
(0.236)\end{array}$ & $\begin{array}{l}-0.323 \\
(0.234)\end{array}$ & $\begin{array}{c}0.237^{* * *} \\
(0.048)\end{array}$ & $\begin{array}{c}0.008 \\
(0.005)\end{array}$ & $\begin{array}{l}0.143^{* *} \\
(0.060)\end{array}$ & 36 & 0.962 \\
\hline Romania & $\begin{array}{c}0.023 \\
(0.016)\end{array}$ & $\begin{array}{l}0.500^{* * *} \\
(0.152)\end{array}$ & $\begin{array}{c}0.059 \\
(0.044)\end{array}$ & $\begin{array}{c}0.418 \\
(0.406)\end{array}$ & $\begin{array}{l}-1.639^{*} \\
(0.809)\end{array}$ & $\begin{array}{l}-0.485 \\
(0.497)\end{array}$ & $\begin{array}{l}0.078^{* *} \\
(0.036)\end{array}$ & $\begin{array}{c}-0.054^{* *} \\
(0.023)\end{array}$ & $\begin{array}{l}0.175^{* * *} \\
(0.047)\end{array}$ & 36 & 0.924 \\
\hline Russia & $\begin{array}{c}-0.003 \\
(0.009)\end{array}$ & $\begin{array}{l}0.774^{* * *} \\
(0.048)\end{array}$ & $\begin{array}{l}0.031^{* *} \\
(0.014)\end{array}$ & $\begin{array}{c}0.092 \\
(0.195)\end{array}$ & $\begin{array}{l}-0.058 \\
(0.369)\end{array}$ & $\begin{array}{c}0.222 \\
(0.426)\end{array}$ & $\begin{array}{c}0.006 \\
(0.027)\end{array}$ & $\begin{array}{c}-0.066^{* * *} \\
(0.010)\end{array}$ & $\begin{array}{c}0.051^{*} \\
(0.027)\end{array}$ & 36 & 0.969 \\
\hline Turkey & $\begin{array}{c}-0.044 \\
(0.048)\end{array}$ & $\begin{array}{l}0.874^{* * *} \\
(0.081)\end{array}$ & $\begin{array}{c}0.164^{*} \\
(0.090)\end{array}$ & $\begin{array}{c}0.463 \\
(0.782)\end{array}$ & $\begin{array}{l}-0.389 \\
(1.521)\end{array}$ & $\begin{array}{c}-0.822 \\
(0.901)\end{array}$ & $\begin{array}{l}0.199^{* *} \\
(0.072)\end{array}$ & $\begin{array}{l}-0.028 \\
(0.019)\end{array}$ & $\begin{array}{c}0.066 \\
(0.118)\end{array}$ & 36 & 0.972 \\
\hline \multicolumn{12}{|l|}{ Latin America } \\
\hline Brazil & $\begin{array}{l}-0.034 \\
(0.036)\end{array}$ & $\begin{array}{l}0.758^{\star \star *} \\
(0.057)\end{array}$ & $\begin{array}{c}0.016 \\
(0.023)\end{array}$ & $\begin{array}{c}-0.775^{\star * *} \\
(0.257)\end{array}$ & $\begin{array}{c}-1.967^{\star *} \\
(0.906)\end{array}$ & $\begin{array}{c}0.637 \\
(0.543)\end{array}$ & $\begin{array}{c}0.453^{\star * *} \\
(0.088)\end{array}$ & $\begin{array}{c}0.002 \\
(0.013)\end{array}$ & $\begin{array}{l}0.409^{\star * *} \\
(0.103)\end{array}$ & 36 & 0.978 \\
\hline Chile & $\begin{array}{c}0.008 \\
(0.017)\end{array}$ & $\begin{array}{c}0.327^{*} \\
(0.168)\end{array}$ & $\begin{array}{l}0.102^{\star *} \\
(0.043)\end{array}$ & $\begin{array}{c}-0.613 \\
(0.471)\end{array}$ & $\begin{array}{l}1.806^{\star \star} \\
(0.669)\end{array}$ & $\begin{array}{c}0.838 \\
(1.641)\end{array}$ & $\begin{array}{l}0.348^{\star * *} \\
(0.120)\end{array}$ & $\begin{array}{c}-0.003 \\
(0.013)\end{array}$ & $\begin{array}{l}0.214^{* * *} \\
(0.076)\end{array}$ & 36 & 0.929 \\
\hline Colombia & $\begin{array}{l}-0.025 \\
(0.033)\end{array}$ & $\begin{array}{l}0.518^{* * *} \\
(0.073)\end{array}$ & $\begin{array}{c}0.032^{*} \\
(0.018)\end{array}$ & $\begin{array}{l}-0.491^{*} \\
(0.246)\end{array}$ & $\begin{array}{c}0.157 \\
(0.403)\end{array}$ & $\begin{array}{c}0.721 \\
(0.631)\end{array}$ & $\begin{array}{c}0.420^{* * *} \\
(0.070)\end{array}$ & $\begin{array}{l}0.037^{* * *} \\
(0.011)\end{array}$ & $\begin{array}{c}0.366^{* * *} \\
(0.089)\end{array}$ & 36 & 0.983 \\
\hline Mexico & $\begin{array}{c}0.032 \\
(0.022)\end{array}$ & $\begin{array}{l}0.858^{* * *} \\
(0.072)\end{array}$ & $\begin{array}{c}0.011 \\
(0.016)\end{array}$ & $\begin{array}{l}0.343^{* *} \\
(0.160)\end{array}$ & $\begin{array}{l}-1.053^{*} \\
(0.590)\end{array}$ & $\begin{array}{l}-0.427 \\
(0.586)\end{array}$ & $\begin{array}{l}0.172^{* *} \\
(0.066)\end{array}$ & $\begin{array}{c}0.013 \\
(0.009)\end{array}$ & $\begin{array}{c}0.132 \\
(0.137)\end{array}$ & 36 & 0.958 \\
\hline Peru & $\begin{array}{c}0.008 \\
(0.012)\end{array}$ & $\begin{array}{l}0.558^{* * *} \\
(0.077)\end{array}$ & $\begin{array}{c}0.033^{*} \\
(0.019)\end{array}$ & $\begin{array}{c}-1.003^{* * *} \\
(0.254)\end{array}$ & $\begin{array}{c}0.556 \\
(0.354)\end{array}$ & $\begin{array}{l}1.832^{* * *} \\
(0.419)\end{array}$ & $\begin{array}{l}0.279^{* * *} \\
(0.042)\end{array}$ & $\begin{array}{c}-0.025 \\
(0.016)\end{array}$ & $\begin{array}{c}0.098 \\
(0.079)\end{array}$ & 36 & 0.948 \\
\hline \multicolumn{12}{|c|}{ Middle East and Africa } \\
\hline Jordan & $\begin{array}{l}-0.003 \\
(0.004)\end{array}$ & $\begin{array}{l}0.885^{\star * *} \\
(0.069)\end{array}$ & $\begin{array}{c}0.001 \\
(0.019)\end{array}$ & $\begin{array}{l}-0.386^{*} \\
(0.215)\end{array}$ & $\begin{array}{c}-0.568 \\
(0.385)\end{array}$ & $\begin{array}{l}-0.300 \\
(0.329)\end{array}$ & $\begin{array}{c}-0.011 \\
(0.061)\end{array}$ & $\begin{array}{c}0.009 \\
(0.016)\end{array}$ & $\begin{array}{c}0.038^{*} \\
(0.020)\end{array}$ & 36 & 0.957 \\
\hline Morocco & $\begin{array}{c}0.000 \\
(0.003)\end{array}$ & $\begin{array}{c}0.822^{* * *} \\
(0.194)\end{array}$ & $\begin{array}{l}0.010^{* *} \\
(0.005)\end{array}$ & $\begin{array}{c}0.085 \\
(0.051)\end{array}$ & $\begin{array}{c}-0.062 \\
(0.114)\end{array}$ & $\begin{array}{c}-0.193^{* *} \\
(0.076)\end{array}$ & $\begin{array}{c}0.001 \\
(0.007)\end{array}$ & $\begin{array}{c}-0.004 \\
(0.004)\end{array}$ & $\begin{array}{c}0.017 \\
(0.014)\end{array}$ & 36 & 0.859 \\
\hline South Africa & $\begin{array}{c}0.024 \\
(0.016)\end{array}$ & $\begin{array}{l}0.825^{\star * *} \\
(0.074)\end{array}$ & $\begin{array}{c}0.030 \\
(0.024)\end{array}$ & $\begin{array}{l}-0.392 \\
(0.274)\end{array}$ & $\begin{array}{l}-0.191 \\
(0.397)\end{array}$ & $\begin{array}{c}0.627 \\
(0.458)\end{array}$ & $\begin{array}{c}0.453^{\star \star *} \\
(0.080)\end{array}$ & $\begin{array}{c}0.025^{\star * *} \\
(0.007)\end{array}$ & $\begin{array}{c}0.003 \\
(0.017)\end{array}$ & 36 & 0.987 \\
\hline
\end{tabular}

Note: Dependent variable is central bank policy rate (in percent). Net capital flows are in percent of GDP. See Appendix for the description of variables and data sources. All regressions include a constant and quarter effects. Robust standard errors reported in parentheses. ${ }^{* \star *}$, ** and * indicate statistical significance at the 1,5 and 10 percent levels, respectively. 
Table A.8 Net Capital Flows and Fiscal Policy Response in Selected EMEs

\begin{tabular}{|c|c|c|c|c|c|c|c|c|c|c|}
\hline & $\begin{array}{l}\text { Net capital } \\
\text { flow s/GDP }\end{array}$ & $\begin{array}{l}\text { Real govt. } \\
\text { spending }\end{array}$ & $\begin{array}{l}\text { US interest } \\
\text { rate }\end{array}$ & $\begin{array}{c}\text { Global market } \\
\text { volatility }\end{array}$ & $\begin{array}{l}\text { Commodity } \\
\text { prices }\end{array}$ & GFC & $\begin{array}{l}\text { Output } \\
\text { gap }\end{array}$ & $\begin{array}{l}\text { Change } \\
\text { in REER }\end{array}$ & Obs. & $\mathrm{R}^{2}$ \\
\hline \multicolumn{11}{|l|}{ Asia } \\
\hline India & $\begin{array}{c}0.126 \\
(0.787)\end{array}$ & $\begin{array}{l}-0.169 \\
(0.213)\end{array}$ & $\begin{array}{c}0.427 \\
(0.566)\end{array}$ & $\begin{array}{c}9.732 \\
(6.314)\end{array}$ & $\begin{array}{l}-13.186 \\
(10.129)\end{array}$ & $\begin{array}{c}-24.252^{\star *} \\
(9.111)\end{array}$ & $\begin{array}{c}-1.412 \\
(1.054)\end{array}$ & $\begin{array}{l}-0.022 \\
(0.308)\end{array}$ & 35 & 0.229 \\
\hline Indonesia & $\begin{array}{l}-0.054 \\
(0.341)\end{array}$ & $\begin{array}{c}0.132 \\
(0.192)\end{array}$ & $\begin{array}{c}0.200 \\
(0.415)\end{array}$ & $\begin{array}{l}-0.441 \\
(3.052)\end{array}$ & $\begin{array}{l}-0.488 \\
(6.577)\end{array}$ & $\begin{array}{c}-2.820 \\
(10.828)\end{array}$ & $\begin{array}{l}-4.766 \\
(3.241)\end{array}$ & $\begin{array}{l}-0.147 \\
(0.160)\end{array}$ & 36 & 0.115 \\
\hline Korea, Rep. & $\begin{array}{l}-0.047 \\
(0.035)\end{array}$ & $\begin{array}{c}0.264^{*} \\
(0.152)\end{array}$ & $\begin{array}{c}0.126^{* * *} \\
(0.033)\end{array}$ & $\begin{array}{l}-0.050 \\
(0.538)\end{array}$ & $\begin{array}{l}-0.015 \\
(0.839)\end{array}$ & $\begin{array}{l}-0.562 \\
(1.393)\end{array}$ & $\begin{array}{l}-0.157 \\
(0.183)\end{array}$ & $\begin{array}{c}-0.063^{* * *} \\
(0.020)\end{array}$ & 36 & 0.743 \\
\hline Malaysia & $\begin{array}{l}-0.050 \\
(0.125)\end{array}$ & $\begin{array}{c}-0.493^{* *} \\
(0.209)\end{array}$ & $\begin{array}{l}-0.656 \\
(0.435)\end{array}$ & $\begin{array}{l}6.043^{*} \\
(2.947)\end{array}$ & $\begin{array}{l}-3.856 \\
(6.498)\end{array}$ & $\begin{array}{l}-7.348 \\
(4.789)\end{array}$ & $\begin{array}{c}0.065 \\
(0.540)\end{array}$ & $\begin{array}{l}-0.612 \\
(0.426)\end{array}$ & 20 & 0.722 \\
\hline Philippines & $\begin{array}{l}-0.068 \\
(0.133)\end{array}$ & $\begin{array}{l}0.570^{* *} \\
(0.218)\end{array}$ & $\begin{array}{c}0.390 \\
(0.263)\end{array}$ & $\begin{array}{l}-1.555 \\
(2.676)\end{array}$ & & $\begin{array}{l}-2.896 \\
(4.226)\end{array}$ & $\begin{array}{l}-0.501 \\
(0.676)\end{array}$ & $\begin{array}{l}-0.092 \\
(0.261)\end{array}$ & 36 & 0.377 \\
\hline Thailand & $\begin{array}{c}0.185 \\
(0.127)\end{array}$ & $\begin{array}{c}0.347 \\
(0.338)\end{array}$ & $\begin{array}{c}0.270 \\
(0.226)\end{array}$ & $\begin{array}{c}-5.652 \\
(5.945)\end{array}$ & $\begin{array}{c}-0.967 \\
(4.565)\end{array}$ & $\begin{array}{c}5.128 \\
(6.554)\end{array}$ & $\begin{array}{c}0.188 \\
(0.285)\end{array}$ & $\begin{array}{c}-0.326 \\
(0.312)\end{array}$ & 36 & 0.466 \\
\hline \multicolumn{11}{|l|}{ Europe } \\
\hline Czech Rep. & $\begin{array}{c}0.033 \\
(0.029)\end{array}$ & $\begin{array}{c}0.490^{* * *} \\
(0.154)\end{array}$ & $\begin{array}{l}-0.042 \\
(0.072)\end{array}$ & $\begin{array}{c}0.555 \\
(0.734)\end{array}$ & $\begin{array}{l}-0.988 \\
(0.949)\end{array}$ & $\begin{array}{l}-0.971 \\
(1.473)\end{array}$ & $\begin{array}{c}-0.150 \\
(0.150)\end{array}$ & $\begin{array}{c}0.054 \\
(0.048)\end{array}$ & 36 & 0.401 \\
\hline Hungary & $\begin{array}{c}0.095 \\
(0.118)\end{array}$ & $\begin{array}{c}0.042 \\
(0.200)\end{array}$ & $\begin{array}{c}0.088 \\
(0.279)\end{array}$ & $\begin{array}{c}1.825 \\
(1.903)\end{array}$ & $\begin{array}{c}0.627 \\
(2.508)\end{array}$ & $\begin{array}{l}-2.124 \\
(2.768)\end{array}$ & $\begin{array}{c}-0.020 \\
(0.321)\end{array}$ & $\begin{array}{c}0.042 \\
(0.137)\end{array}$ & 36 & 0.127 \\
\hline Poland & $\begin{array}{c}0.107 \\
(0.117)\end{array}$ & $\begin{array}{c}0.171 \\
(0.234)\end{array}$ & $\begin{array}{l}0.262^{* *} \\
(0.119)\end{array}$ & $\begin{array}{c}1.872^{*} \\
(1.075)\end{array}$ & $\begin{array}{c}2.920 \\
(1.735)\end{array}$ & $\begin{array}{c}2.616 \\
(1.957)\end{array}$ & $\begin{array}{c}-0.647 \\
(0.417)\end{array}$ & $\begin{array}{c}0.005 \\
(0.050)\end{array}$ & 36 & 0.425 \\
\hline Romania & $\begin{array}{l}-0.072 \\
(0.378)\end{array}$ & $\begin{array}{l}-0.104 \\
(0.296)\end{array}$ & $\begin{array}{l}-0.213 \\
(0.639)\end{array}$ & $\begin{array}{c}2.516 \\
(8.304)\end{array}$ & $\begin{array}{l}-12.673 \\
(8.457)\end{array}$ & $\begin{array}{c}-3.413 \\
(10.276)\end{array}$ & $\begin{array}{c}0.971 \\
(0.863)\end{array}$ & $\begin{array}{l}-0.325 \\
(0.374)\end{array}$ & 36 & 0.129 \\
\hline Russia & $\begin{array}{l}-0.106^{*} \\
(0.061)\end{array}$ & $\begin{array}{l}0.657^{\star * \star} \\
(0.168)\end{array}$ & $\begin{array}{c}0.007 \\
(0.140)\end{array}$ & $\begin{array}{l}-1.836 \\
(1.091)\end{array}$ & $\begin{array}{l}-2.977^{*} \\
(1.696)\end{array}$ & $\begin{array}{l}1.595 \\
(2.643)\end{array}$ & $\begin{array}{l}0.305^{\star *} \\
(0.143)\end{array}$ & $\begin{array}{l}-0.231^{*} \\
(0.121)\end{array}$ & 36 & 0.809 \\
\hline Turkey & $\begin{array}{c}-0.025 \\
(0.258)\end{array}$ & $\begin{array}{c}0.109 \\
(0.149)\end{array}$ & $\begin{array}{c}0.180 \\
(0.209)\end{array}$ & $\begin{array}{c}-3.003 \\
(2.797)\end{array}$ & $\begin{array}{c}2.159 \\
(4.511)\end{array}$ & $\begin{array}{c}0.242 \\
(4.439)\end{array}$ & $\begin{array}{c}0.109 \\
(0.202)\end{array}$ & $\begin{array}{c}0.012 \\
(0.067)\end{array}$ & 36 & 0.245 \\
\hline \multicolumn{11}{|l|}{ Latin America } \\
\hline Brazil & $\begin{array}{c}0.201^{*} \\
(0.110)\end{array}$ & $\begin{array}{c}0.011 \\
(0.190)\end{array}$ & $\begin{array}{l}-0.018 \\
(0.081)\end{array}$ & $\begin{array}{l}-0.783 \\
(1.152)\end{array}$ & $\begin{array}{c}0.376 \\
(1.702)\end{array}$ & $\begin{array}{l}5.720^{*} \\
(2.906)\end{array}$ & $\begin{array}{c}0.146 \\
(0.267)\end{array}$ & $\begin{array}{c}0.043 \\
(0.031)\end{array}$ & 36 & 0.322 \\
\hline Chile & $\begin{array}{c}0.112^{*} \\
(0.061)\end{array}$ & $\begin{array}{c}0.517^{* * *} \\
(0.164)\end{array}$ & $\begin{array}{c}0.044 \\
(0.185)\end{array}$ & $\begin{array}{c}1.488 \\
(1.284)\end{array}$ & $\begin{array}{l}-1.030 \\
(1.664)\end{array}$ & $\begin{array}{l}-0.888 \\
(2.433)\end{array}$ & $\begin{array}{c}-0.459 \\
(0.314)\end{array}$ & $\begin{array}{l}-0.111^{*} \\
(0.060)\end{array}$ & 36 & 0.791 \\
\hline Mexico & $\begin{array}{c}0.072 \\
(0.081)\end{array}$ & $\begin{array}{l}0.516^{* *} \\
(0.200)\end{array}$ & $\begin{array}{l}-0.008 \\
(0.043)\end{array}$ & $\begin{array}{c}0.187 \\
(0.611)\end{array}$ & $\begin{array}{c}-0.607 \\
(1.392)\end{array}$ & $\begin{array}{l}2.578^{* *} \\
(1.005)\end{array}$ & $\begin{array}{c}0.067 \\
(0.115)\end{array}$ & $\begin{array}{c}0.018 \\
(0.033)\end{array}$ & 36 & 0.565 \\
\hline Peru & $\begin{array}{l}-0.097 \\
(0.140)\end{array}$ & $\begin{array}{c}0.094 \\
(0.210)\end{array}$ & $\begin{array}{c}-0.147 \\
(0.274)\end{array}$ & $\begin{array}{c}-0.844 \\
(2.716)\end{array}$ & $\begin{array}{l}-4.421 \\
(4.956)\end{array}$ & $\begin{array}{l}-4.019 \\
(6.127)\end{array}$ & $\begin{array}{c}-0.532 \\
(0.580)\end{array}$ & $\begin{array}{c}0.112 \\
(0.201)\end{array}$ & 36 & 0.313 \\
\hline
\end{tabular}

Note: Dependent variable is cyclical component of real government consumption spending (in percent of trend). Net capital flows are in percent of GDP. See Appendix for the description of other variables and data sources. All regressions include a constant and quarter effects. Ro bust standard errors are reported in parentheses. ${ }^{* \star *},{ }^{* \star}$ and * indicate statistical significance at the 1,5 and 10 percent levels, respectively. 
Table A.9 Net Capital Flows and Macroprudential Policy Response in Selected EMEs

\begin{tabular}{|c|c|c|c|c|c|c|c|c|}
\hline & $\begin{array}{l}\text { Net capital } \\
\text { flow s/GDP }\end{array}$ & $\begin{array}{l}\text { US interest } \\
\text { rate }\end{array}$ & $\begin{array}{c}\text { Global } \\
\text { market vol. }\end{array}$ & GFC & $\begin{array}{c}\text { Real GDP } \\
\text { grow th }\end{array}$ & Initial RR & Obs. & $\mathrm{R}^{2}$ \\
\hline \multicolumn{9}{|c|}{ [a] Overall change in macropudential policy } \\
\hline Brazil & $\begin{array}{c}-0.089 \\
(0.090)\end{array}$ & $\begin{array}{c}-0.206 \\
(0.309)\end{array}$ & $\begin{array}{c}2.025^{*} \\
(1.210)\end{array}$ & $\begin{array}{c}-8.207^{* * *} \\
(3.184)\end{array}$ & $\begin{array}{c}-0.410 \\
(0.344)\end{array}$ & & 36 & 0.221 \\
\hline Colombia & $\begin{array}{c}-0.051 \\
(0.071)\end{array}$ & $\begin{array}{c}0.006 \\
(0.108)\end{array}$ & $\begin{array}{c}-0.270 \\
(0.881)\end{array}$ & $\begin{array}{c}0.817 \\
(1.148)\end{array}$ & $\begin{array}{c}-0.845^{\star *} \\
(0.352)\end{array}$ & & 36 & 0.253 \\
\hline Croatia & $\begin{array}{l}0.256^{* *} \\
(0.124)\end{array}$ & $\begin{array}{c}0.264 \\
(0.163)\end{array}$ & $\begin{array}{c}-3.004 \\
(2.793)\end{array}$ & $\begin{array}{c}0.296 \\
(2.562)\end{array}$ & $\begin{array}{c}0.063 \\
(0.248)\end{array}$ & & 36 & 0.707 \\
\hline Hungary & $\begin{array}{c}0.090^{* * *} \\
(0.028)\end{array}$ & $\begin{array}{c}0.011 \\
(0.056)\end{array}$ & $\begin{array}{l}1.442^{* *} \\
(0.663)\end{array}$ & $\begin{array}{c}-5.211^{* * *} \\
(1.381)\end{array}$ & $\begin{array}{c}-0.064 \\
(0.265)\end{array}$ & & 36 & 0.197 \\
\hline India & $\begin{array}{c}-0.051 \\
(0.091)\end{array}$ & $\begin{array}{c}-0.080 \\
(0.115)\end{array}$ & $\begin{array}{c}-2.845^{\star *} \\
(1.137)\end{array}$ & $\begin{array}{c}-2.547 \\
(1.601)\end{array}$ & $\begin{array}{l}-0.343 \\
(0.409)\end{array}$ & & 36 & 0.230 \\
\hline Indonesia & $\begin{array}{c}0.087^{*} \\
(0.049)\end{array}$ & $\begin{array}{c}-0.036 \\
(0.052)\end{array}$ & $\begin{array}{c}-0.504 \\
(0.943)\end{array}$ & $\begin{array}{c}-3.195^{\star * *} \\
(0.829)\end{array}$ & $\begin{array}{l}-0.254 \\
(0.718)\end{array}$ & & 36 & 0.0745 \\
\hline Korea & $\begin{array}{c}0.132^{*} \\
(0.074)\end{array}$ & $\begin{array}{c}0.005 \\
(0.063)\end{array}$ & $\begin{array}{c}-0.903 \\
(0.866)\end{array}$ & $\begin{array}{c}-4.151^{* * *} \\
(0.923)\end{array}$ & $\begin{array}{l}-0.096 \\
(0.415)\end{array}$ & & 36 & 0.139 \\
\hline Poland & $\begin{array}{c}-0.009 \\
(0.052)\end{array}$ & $\begin{array}{c}-0.310 \\
(0.250)\end{array}$ & $\begin{array}{c}0.772 \\
(1.226)\end{array}$ & $\begin{array}{c}-5.402^{* * *} \\
(1.954)\end{array}$ & $\begin{array}{c}-1.271^{* *} \\
(0.620)\end{array}$ & & 36 & 0.281 \\
\hline Romania & $\begin{array}{c}0.016 \\
(0.025)\end{array}$ & $\begin{array}{l}-0.296^{*} \\
(0.170)\end{array}$ & $\begin{array}{c}-0.758 \\
(1.056)\end{array}$ & $\begin{array}{c}-1.929 \\
(1.869)\end{array}$ & $\begin{array}{c}0.223 \\
(0.292)\end{array}$ & & 36 & 0.180 \\
\hline Turkey & $\begin{array}{c}0.053 \\
(0.060)\end{array}$ & $\begin{array}{c}-0.012 \\
(0.069)\end{array}$ & $\begin{array}{c}0.465 \\
(0.963)\end{array}$ & $\begin{array}{c}-3.976^{* * *} \\
(1.035)\end{array}$ & $\begin{array}{c}0.018 \\
(0.120)\end{array}$ & & 36 & 0.0550 \\
\hline \multicolumn{9}{|c|}{ [b] Reserve requirements } \\
\hline Brazil & $\begin{array}{l}0.056^{*} \\
(0.032)\end{array}$ & $\begin{array}{l}-0.012 \\
(0.022)\end{array}$ & $\begin{array}{l}-0.599^{*} \\
(0.296)\end{array}$ & $\begin{array}{l}-1.146 \\
(0.944)\end{array}$ & $\begin{array}{l}-0.172 \\
(0.114)\end{array}$ & $\begin{array}{c}0.725^{\star * *} \\
(0.137)\end{array}$ & 36 & 0.906 \\
\hline Colombia & $\begin{array}{l}0.181 \\
(0.181)\end{array}$ & $\begin{array}{l}0.261 \\
(0.218)\end{array}$ & $\begin{array}{l}0.473 \\
(1.761)\end{array}$ & $\begin{array}{l}-2.521 \\
(2.004)\end{array}$ & $\begin{array}{l}-0.046 \\
(0.849)\end{array}$ & $\begin{array}{l}0.798^{\star \star \star} \\
(0.199)\end{array}$ & 36 & 0.613 \\
\hline Croatia & $\begin{array}{l}0.015 \\
(0.018)\end{array}$ & $\begin{array}{l}0.075 \\
(0.066)\end{array}$ & $\begin{array}{l}-0.165 \\
(0.334)\end{array}$ & $\begin{array}{l}0.099 \\
(1.013)\end{array}$ & $\begin{array}{l}0.049 \\
(0.086)\end{array}$ & $\begin{array}{l}0.781^{* * *} \\
(0.179)\end{array}$ & 36 & 0.844 \\
\hline Hungary & $\begin{array}{l}0.063 \\
(0.053)\end{array}$ & $\begin{array}{l}0.010 \\
(0.421)\end{array}$ & $\begin{array}{l}-3.520 \\
(2.726)\end{array}$ & $\begin{array}{l}-20.713 \\
(13.752\end{array}$ & $\begin{array}{l}-0.086 \\
(0.584)\end{array}$ & $\begin{array}{l}0.886^{* * *} \\
(0.068)\end{array}$ & 36 & 0.934 \\
\hline India & $\begin{array}{l}0.002 \\
(0.026)\end{array}$ & $\begin{array}{l}-0.023 \\
(0.035)\end{array}$ & $\begin{array}{l}-0.238 \\
(0.282)\end{array}$ & $\begin{array}{l}-1.933^{* *} \\
(0.915)\end{array}$ & $\begin{array}{l}0.057 \\
(0.064)\end{array}$ & $\begin{array}{l}1.107^{* * *} \\
(0.124)\end{array}$ & 36 & 0.881 \\
\hline Peru & $\begin{array}{l}0.091 \\
(0.070)\end{array}$ & $\begin{array}{l}-0.096 \\
(0.160)\end{array}$ & $\begin{array}{l}1.333 \\
(1.418)\end{array}$ & $\begin{array}{l}-2.692 \\
(2.529)\end{array}$ & $\begin{array}{l}-0.254 \\
(0.318)\end{array}$ & $\begin{array}{c}0.885^{* * *} \\
(0.071)\end{array}$ & 36 & 0.930 \\
\hline Poland & $\begin{array}{l}0.001 \\
(0.005)\end{array}$ & $\begin{array}{l}-0.001 \\
(0.004)\end{array}$ & $\begin{array}{l}-0.154 \\
(0.116)\end{array}$ & $\begin{array}{l}0.286 \\
(0.209)\end{array}$ & $\begin{array}{l}0.031 \\
(0.032)\end{array}$ & $\begin{array}{c}0.753^{* * *} \\
(0.163)\end{array}$ & 36 & 0.707 \\
\hline Romania & $\begin{array}{l}0.015 \\
(0.018)\end{array}$ & $\begin{array}{l}0.075 \\
(0.066)\end{array}$ & $\begin{array}{l}-0.165 \\
(0.334)\end{array}$ & $\begin{array}{l}0.099 \\
(1.013)\end{array}$ & $\begin{array}{l}0.049 \\
(0.086)\end{array}$ & $\begin{array}{l}0.781^{* * *} \\
(0.179)\end{array}$ & 36 & 0.844 \\
\hline Turkey & $\begin{array}{l}0.052^{*} \\
(0.027)\end{array}$ & $\begin{array}{l}-0.040 \\
(0.033)\end{array}$ & $\begin{array}{l}-0.873 \\
(0.542)\end{array}$ & $\begin{array}{l}3.070^{* *} \\
(1.231)\end{array}$ & $\begin{array}{l}0.154^{* *} \\
(0.072)\end{array}$ & $\begin{array}{l}0.729^{* * *} \\
(0.135)\end{array}$ & 36 & 0.887 \\
\hline Uruguay & $\begin{array}{l}0.032^{*} \\
(0.018)\end{array}$ & $\begin{array}{l}-0.035 \\
(0.041)\end{array}$ & $\begin{array}{l}-0.456 \\
(0.419)\end{array}$ & $\begin{array}{l}1.397^{*} \\
(0.738)\end{array}$ & $\begin{array}{l}0.069 \\
(0.100)\end{array}$ & $\begin{array}{l}0.936^{* * *} \\
(0.139)\end{array}$ & 32 & 0.794 \\
\hline
\end{tabular}

Notes: In top panel [a], the dependent variable is a binary variable equal to one if any macroprudential policy was tightened, and zero otherwise. In bottom panel [b], the dependent variable is average reserve requirement (RR) on local currency liabilities. All estimations in the to p panel are conducted using a pro bit model, and pseudo-R2 is reported. Initial RR is one-period lagged RR. All regressions include a constant. Robust standard errors are reported in parentheses. ${ }^{* \star *},{ }^{\star *}$ and ${ }^{*}$ indicate statistical significance at the 1,5 and 10 percent levels, respectively. 
Table A.10 Net Capital Flows and Inflow Controls in Selected EMEs

\begin{tabular}{|c|c|c|c|c|c|c|}
\hline & $\begin{array}{l}\text { Net capital } \\
\text { flow s/GDP }\end{array}$ & $\begin{array}{l}\text { US interest } \\
\text { rate }\end{array}$ & $\begin{array}{c}\text { Global market } \\
\text { volatility }\end{array}$ & GFC & Obs. & $\begin{array}{c}\text { Pseudo- } \\
R^{2}\end{array}$ \\
\hline Brazil & $\begin{array}{l}0.392^{\star *} \\
(0.165)\end{array}$ & $\begin{array}{l}-0.029 \\
(0.072)\end{array}$ & $\begin{array}{c}0.974 \\
(0.852)\end{array}$ & $\begin{array}{c}-3.205^{\star * \star} \\
(1.162)\end{array}$ & 36 & 0.393 \\
\hline Colombia & $\begin{array}{l}-0.071 \\
(0.077)\end{array}$ & $\begin{array}{l}-0.071 \\
(0.212)\end{array}$ & $\begin{array}{l}-0.627 \\
(0.429)\end{array}$ & $\begin{array}{c}-3.578^{* * *} \\
(0.623)\end{array}$ & 36 & 0.050 \\
\hline India & $\begin{array}{l}0.436^{\star *} \\
(0.195)\end{array}$ & $\begin{array}{l}0.239^{* *} \\
(0.116)\end{array}$ & $\begin{array}{l}-3.013 \\
(1.961)\end{array}$ & $\begin{array}{c}2.465 \\
(2.836)\end{array}$ & 36 & 0.335 \\
\hline Indonesia & $\begin{array}{c}0.012 \\
(0.088)\end{array}$ & $\begin{array}{c}-0.350^{* *} \\
(0.171)\end{array}$ & $\begin{array}{l}-1.882 \\
(1.177)\end{array}$ & $\begin{array}{c}-2.475^{\star *} \\
(1.069)\end{array}$ & 36 & 0.173 \\
\hline Korea & $\begin{array}{l}-0.007 \\
(0.055)\end{array}$ & $\begin{array}{l}-0.056 \\
(0.063)\end{array}$ & $\begin{array}{l}1.035 \\
(0.884)\end{array}$ & $\begin{array}{c}-5.604^{* * *} \\
(1.203)\end{array}$ & 36 & 0.093 \\
\hline Philippines & $\begin{array}{l}0.102^{* *} \\
(0.045)\end{array}$ & $\begin{array}{c}0.016 \\
(0.034)\end{array}$ & $\begin{array}{l}-0.810^{*} \\
(0.416)\end{array}$ & $\begin{array}{c}-1.874^{\star \star \star} \\
(0.568)\end{array}$ & 36 & 0.132 \\
\hline Thailand & $\begin{array}{c}0.011 \\
(0.025)\end{array}$ & $\begin{array}{l}-0.277 \\
(0.186)\end{array}$ & $\begin{array}{l}-2.920^{*} \\
(1.635)\end{array}$ & $\begin{array}{l}-1.805 \\
(0.000)\end{array}$ & 36 & 0.170 \\
\hline Turkey & $\begin{array}{l}0.148^{* *} \\
(0.069)\end{array}$ & $\begin{array}{l}-0.127 \\
(0.118)\end{array}$ & $\begin{array}{l}1.842^{* *} \\
(0.921)\end{array}$ & $\begin{array}{c}-4.013^{\star * *} \\
(1.115)\end{array}$ & 36 & 0.270 \\
\hline
\end{tabular}

Note: Dependent variable is a binary variable equal to one for tightening of capital inflow controls. All regressions include a constant and are estimated as a probit model. Robust standard errors reported in parentheses. ${ }^{* * *},{ }^{* *}$ and * indicate statistical significance at the 1,5 and 10 percent levels, respectively.

Table A.11 Net Capital Flows and Outflow Controls in Selected EMEs

\begin{tabular}{|c|c|c|c|c|c|c|}
\hline & $\begin{array}{l}\text { Net capital } \\
\text { flow s/GDP }\end{array}$ & $\begin{array}{l}\text { US interest } \\
\text { rate }\end{array}$ & $\begin{array}{c}\text { Global market } \\
\text { volatility }\end{array}$ & GFC & Obs. & $\begin{array}{c}\text { Pseudo- } \\
R^{2}\end{array}$ \\
\hline Brazil & $\begin{array}{c}0.144 \\
(0.120)\end{array}$ & $\begin{array}{l}0.348^{*} \\
(0.190)\end{array}$ & $\begin{array}{l}-5.826^{* *} \\
(2.726)\end{array}$ & $\begin{array}{c}4.098 \\
(4.298)\end{array}$ & 36 & 0.481 \\
\hline Colombia & $\begin{array}{l}-0.096 \\
(0.133)\end{array}$ & $\begin{array}{l}-0.043 \\
(0.041)\end{array}$ & $\begin{array}{c}0.344 \\
(0.631)\end{array}$ & $\begin{array}{c}-4.469^{* \star *} \\
(0.649)\end{array}$ & 36 & 0.0581 \\
\hline India & $\begin{array}{c}0.086 \\
(0.097)\end{array}$ & $\begin{array}{c}0.048 \\
(0.070)\end{array}$ & $\begin{array}{c}0.276 \\
(0.998)\end{array}$ & $\begin{array}{c}-4.038^{* * \star} \\
(1.469)\end{array}$ & 36 & 0.0632 \\
\hline Korea & $\begin{array}{c}0.062 \\
(0.061)\end{array}$ & $\begin{array}{c}0.052 \\
(0.048)\end{array}$ & $\begin{array}{l}-0.741 \\
(0.948)\end{array}$ & $\begin{array}{c}-3.335^{\star \star *} \\
(0.884)\end{array}$ & 36 & 0.0839 \\
\hline Philippines & $\begin{array}{l}-0.003 \\
(0.048)\end{array}$ & $\begin{array}{l}-0.150 \\
(0.164)\end{array}$ & $\begin{array}{l}1.577^{*} \\
(0.887)\end{array}$ & $\begin{array}{l}-0.352 \\
(1.246)\end{array}$ & 36 & 0.209 \\
\hline Thailand & $\begin{array}{c}0.011 \\
(0.028)\end{array}$ & $\begin{array}{l}-0.110 \\
(0.085)\end{array}$ & $\begin{array}{l}-0.451 \\
(0.761)\end{array}$ & $\begin{array}{c}-4.353^{\star \star *} \\
(0.745)\end{array}$ & 36 & 0.0681 \\
\hline Turkey & $\begin{array}{c}0.061 \\
(0.047)\end{array}$ & $\begin{array}{l}-0.376^{*} \\
(0.195)\end{array}$ & $\begin{array}{c}0.434 \\
(0.935)\end{array}$ & $\begin{array}{l}2.789^{* \star} \\
(1.292)\end{array}$ & 36 & 0.294 \\
\hline South Africa & $\begin{array}{l}-0.100 \\
(0.075)\end{array}$ & $\begin{array}{l}-0.176 \\
(0.107)\end{array}$ & $\begin{array}{c}0.271 \\
(0.926)\end{array}$ & $\begin{array}{c}0.382 \\
(1.346)\end{array}$ & 36 & 0.144 \\
\hline
\end{tabular}

Note: Dependent variable is a binary variable equal to one for relaxation of outflow controls. All regressions include a constant and are estimated as a probit model. Robust standard errors reported in parentheses. ${ }^{* *},{ }^{* \star}$ and ${ }^{*}$ indicate statistical significance at the 1,5 and 10 percent levels, respectively.

Table A.12 Macro-Financial Risks in Surges and Normal Flows (in percent)

\begin{tabular}{lll}
\hline & Surges & Normal flows \\
\cline { 2 - 3 } Change in real domestic credit & $11.7^{* * *}$ & 9.0 \\
Output gap & $0.6^{* * *}$ & 0.1 \\
Change in REER & 2.7 & 1.8 \\
\hline
\end{tabular}

Source: Authors' estimates.

Note: Statistics are the average (y-o-y) percentage change in real domestic credit and REER, and the output gap in surge and normal flow observations. Sample comprises those observations for which information on all policy instruments is available. ${ }^{* * *}$ indicates that the difference between the two group means is statistically significant at the 1 percent level, respectively. 